\title{
HEGEMONY AND MEDIATIONS IN MELODRAMA OF THE GOLDEN AGE OF MEXICAN CINEMA
}

By

Dave Evans

A thesis

submitted to the Victoria University of Wellington in fulfilment of the requirements for the degree of Masters of Arts

in Spanish and Latin American Studies

Victoria University of Wellington 


\begin{abstract}
The influence of the mass media is a contentious issue, especially in regards to the Golden Age of Mexican Cinema in the mid-twentieth century. These melodramatic films have often been viewed by critics as instruments of hegemony. However, melodrama contains an inherent ambivalence, as it not only has a potential for imparting dominant messages but also offers a platform from which to defy and exceed the restraining boundaries imposed by dominant ideologies. An examination of a number of important Golden Age films, especially focussing on their contradictory tensions and their portrayals of modernity, illustrates this. The Nosotros los pobres series serves as an example of how melodramatic elements are incorporated into popular Mexican films and how melodrama could be used as an ideological tool to encourage the state's goals. Similarly, the maternal melodrama Cuando los hijos se van uses the family to represent the processes of conflict and negotiation that Mexicans experienced as a result of modernization. Consistent with the reactionary nature of melodrama and its simultaneous suggestive potential, the film combines a Catholic worldview with an underlying allegory of moving forward. The issue of progress is also at the centre of a number of films starring iconic actor Pedro Infante, which offer an avenue for exploring what modernisation might mean for male identity in Mexico. His films show a masculinity in transition and how lower-class men could cope with this change. Likewise, the depiction of women in Golden Age film overall supports the stabilising goals of the 1940s Revolutionary government, while also providing some transgressive figures.

Therefore, these films helped the Mexican audience process the sudden modernization of the post-Revolutionary period, which was in the state's best interest; however, the masses were also able to reconfigure the messages of these films and find their own sense of meaning in them.
\end{abstract}




\section{TABLE OF CONTENTS}

Introduction .4

Chapter One: Hegemony, Melodrama, and Mexican Film........................8

History of Melodrama and Outline of Its Main Features......................8

Criticism on Latin American Melodrama: Gramsci and the Frankfurt School...12

Approaches to the 'Culture Industry' in Latin America..........................15

Mexican Film Melodrama as an Ideological Instrument of the State............18

Mexican Film Melodrama as a Form of Counter-Hegemony and Subversion...20

Chapter Two: Crying, Suffering, and the Containment of Social Tensions in the

Nosotros Los Pobres Trilogy

Plot Synopses and Review of Existing Criticism............................23

The Idealisation of the Vecindad and the Family...........................26

The Exaltation of the Poor's Emotions to Compensate for Their Poverty........27

Chance as the Defining Force in the Characters' Lives.......................30

Chapter Three: Maternity, Family, and Religion in Cuando los hijos se van.........33

Religious Symbolism and Messages of Regression in Cuando los hijos se van.34

A Modernising Drive in Cuando los hijos se van.

Chapter Four: Pedro Infante and the Cinematic Representation of

Masculinities.................................................................46

Masculinity as Performance in Mexico...................................46

Pedro Infante's Stardom and the Importance of His Body....................49

The Traditional Collides with the Modern in Arriba las mujeres.................52

Openness and Virility in the Nosotros los pobres Trilogy.....................57

Infante's Buddy Films as a Model of Urban Homosocial Bonding.............63

Chapter Five: Women, Motherhood, and Modernity............................70

Women in Mexican Society........................................... 70

Images of Regression in Las abandonadas................................72

The Femme Fatale and Doña Bárbara ...................................77

Conclusion....................................................................84

Bibliography of Works Cited................................................86 


\section{INTRODUCTION}

The Golden Age of Mexican Cinema is one of the most important cultural developments in twentieth-century Mexico. It was a period of unprecedented output for Mexican cinema: 75 films were made in 1944, the highest number of films made in one year up to that point (Mora 1982: 69). According to Carlos Monsiváis, one of the most significant contributors to criticism on Mexican Cinema, the Golden Age approximately took place from 1935 to 1955 (1993: 144). ${ }^{1}$ There were a number of socio-historical factors which led to this period. After a number of popular films produced and released in the 1930s, the Mexican film industry's continued success throughout the 1940s was secured by the support of the United States during World War II. The two countries shared a common enemy in the form of the Axis powers and the U.S. saw film as an effective way to sway popular opinion toward the war effort. King succinctly explains why the success of cinema occurred when it did:

Throughout the 1930s [...] the industry gained in strength. [...] The success of Mexican cinema in the 1940s was due to a series of circumstances: the added commercial opportunities offered by the war, the emergence of a number of important directors and cinematographers and the consolidation of a star system resting on proven formulae. (1990: 47)

Mexican cinema, thus, shared technical and formal similarities with Hollywood. Monsiváis claims that 'from Hollywood came the genres, the stylistic conventions, the formal skills' (1993: 141). In fact, Mexico was able to bolster its film industry partly by becoming partners with the U.S. in the anti-fascist effort, who provided the country with raw film stock in exchange for their support of the Allied cause. However, this does not mean that Mexican film was a copy of Hollywood in every respect. Berg notes that 'though following the classical Hollywood narrative paradigm, Mexico's Golden Age cinema was distinctly Mexican' because 'they told specifically Mexican stories, dealt with Mexican issues, and treated their subjects in such a manner that Mexican ideology was made manifest' (1992: 15-16; italics in the original).

In order to understand the extent of this cinema's Mexicanness, it is important to place its emergence and development in the socio-cultural specificities of Mexico at this

\footnotetext{
${ }^{1}$ There is some debate in criticism with regards to the duration of the Golden Age of Mexican cinema. Charles Ramírez Berg considers that it began with 'the first Spanish-language blockbuster' Allá en el Rancho Grande (1936), directed by Fernando de Fuentes (1998: 13). John King, by contrast, sees the start of Dolores del Río's Mexican career in 1943 as a defining moment (1990: 35). According to Berg the period was finished by 1956 (1998: 16, 21). Both King and Emilio García Riera consider the Golden Age to have lasted from 1941-1945, coinciding with the presidency of Manuel Ávila Camacho (1940-1946) and World War II.
} 
time, including the historical and socio-cultural factors and developments that led to Mexico's Golden Age of Cinema in the late 1930s and throughout the 1940s, when Mexican film was at the pinnacle of its success and popularity. The most significant historical event in twentieth-century Mexican history is unquestionably the Mexican Revolution, which began in 1910 and continued until 1917. Before this time, from 1876 to 1911, Mexico had been under the rule of Porfirio Díaz, who ensured a traditional and patriarchal society in which Catholicism played a major role. The Mexican Revolution began as a revolt against these traditional ways. Partly due to the Mexican Revolution, traditional ideas, particularly those pertaining to the relationship between the Church and the State, were given less weight in Mexico as the government embarked on a process of secularisation (Mora 1982: 15-21). Although the government had changed, the Mexican people had not. Because of the deeply entrenched religious convictions of the popular classes, it was clear that the Sacred, to use Peter Brooks's term, was still considered very important for many Mexicans. ${ }^{2}$ A concrete example of this was the Cristeros War, a popular uprising between 1926 and 1929. Believing that President Plutarco Elías Calles was trying to take religion out of society with anticlerical steps such as closing Catholic schools and hindering expression of religion, a number of Mexicans rose up against what they considered to be an attack on their beliefs by the secular government. In addition to an unknown number of civilians, 90,000 people died in combat. From this conflict and others it seemed clear that the lower-class Mexicans were predominantly on the side of tradition (Rowe 1987: 20-21, Purnell 1999: 1, Niblo 1991: 1). The time period of the Golden Age of Cinema also coincided with the 'Mexican miracle', which Eduardo de la Vega Alfaro defines as 'a process of accelerated industrialisation which substantially changed the face of the nation' when 'a predominantly agricultural economy was transformed into a manufacturing one, and an agrarian society began to make the qualitative leap into a typically urban one' (1995: 3). According to Andrea Noble, the immigrants from the rural areas were the 'audience, newly arrived and more than likely bewildered by the size, accelerated pace and anonymity of life in the major urban centres, that emerged as the principal consumers of the national film product' (2005: 75).

One of the genres that defined the Golden Age is melodrama, with subgenres such

\footnotetext{
${ }^{2}$ According to Brooks, the Sacred refers to the traditional beliefs based on Christianity which emphasise the spiritual realm and its relation to all areas of life, as opposed to secularism which either negates the existence of or diminishes the importance of the spiritual domain. Brooks considers that a weakening of the Sacred occurs when the Church and its beliefs are questioned and attacked, society's homogeneous nature and hierarchical structure begin to disintegrate, and cultural forms reject ideas implicit in genres such as the tragedy or the comedy of manners, allowing other genres such as melodrama to become more prominent (1976: 15).
} 
as the maternal melodrama and the family melodrama. Many of these films can be understood as a reaction against the incomprehensibly violent events of the Mexican Revolution and are intended to help the audience move on from that past. They reflect on the urban/rural transformations taking place at the time, as the majority of Mexicans lived outside of cities in the 1930s and early 1940s. According to Serge Gruzinksi, 'the images of Mexican cinema, during its golden age in particular, prepared the farmer and town masses for the trauma of the industrialisation of the 40s' (2001: 222). The present thesis carries out a study of the use of melodrama in these Golden Age films, arguing that it a style of storytelling that offers ambiguous possibilities. In one sense, it was used by the dominant ideology to promote its ideals, yet at the same time it opened up spaces for contestation of these ideas and alternative ways of seeing modernity in Mexico.

This thesis is divided into five chapters. Chapter One introduces the major theoretical considerations in analysing these Mexican films. It provides a brief history of melodrama and an outline of the genre's main features. The chapter also summarises the ideas of important European intellectuals on mass culture such as Gramsci and those associated with the Frankfurt School. These scholars influenced Latin American theorists in the 1970s, who tended to view mass culture as an instrument of hegemony. However, some later intellectuals rejected the simplicity of these views. The chapter ends by discussing how Mexican film melodrama can work as a tool of the state and how it may also lend itself to counter-hegemonic viewing by audiences.

Chapter Two offers an analysis of one of the most important Mexican melodramas, Nosotros los pobres (1948), and its two sequels Ustedes los ricos (1948) and Pepe el toro (1952). It shows how the concepts discussed in the first chapter are present in the trilogy. The filmmakers use melodramatic conventions to aid the Mexican transition to modernity and romanticise the city environment, especially for the lower classes. In these films emotions and sentimentality are appealed to in order to maintain the status quo in terms of class division, thus using melodrama's features to support the Mexican state's goals. Overall, the analysis agrees with the existing criticism on the films in that there is a clear intention behind the Nosotros los pobres trilogy to keep the social tensions resulting from rapid modernisation under control.

Chapter Three deals with maternity, family, and religion in early Mexican film. It characterises the 1941 film Cuando los hijos se van as a Catholic family melodrama, particularly paying attention to the allegorical nature of the film. Seen through the eyes of Sara García's mother figure, the film shows a traditional Mexican family in which the sons and daughters do not match the high expectations of the parents. The family and 
Christianity are closely linked by the symbolic characters such as Raimundo, the good son who is falsely accused and sent out of the house by his father. The ideas of religion and family tie into a broader issue: that of modernity versus tradition in the wake of the Mexican Revolution. This section examines the film's examples of modern thinking and technology in juxtaposition to the beliefs of the Rosales family.

Chapters Four and Five explore more deeply the gender roles of characters in Mexican films by examining the flawed ideologies of machismo and marianismo and engaging with critical perspectives on several important films such as Arriba las mujeres (1943) and A toda máquina (1951). In most of these films men and women were given roles as best fit the social and political environment of post-Revolutionary Mexico. Male identity in Golden Age films is in Pedro Infante and the characters he played, which are examined in chapter four. This chapter argues that they illustrate how to respond to the modernisation and urbanisation of Mexico and suggest that modernity can allow for the maintenance of machista values. Through an analysis of three of Infante's characters, this chapter demonstrates how the Mexican actor personifies the concerns of Mexican society and masculinity during the Golden Age of Cinema.

The fifth chapter concentrates on women in post-Revolutionary Mexico by looking at two specific film melodramas. In the maternal melodrama Las abandonadas (1945) famous actress Dolores del Río plays a struggling mother named Margot whose devotion to her son is the most important part of her life. On the one hand, my analysis of the film shows that the representation of a sacrificial mother works within the Mexican state's ideology. On the other hand, Doña Bárbara (1943) displays some suggestive qualities in its depiction of the femme fatale main character, played by María Félix. The film depicts a clash between modernity and traditionalism, an example of 'civilisation' versus 'barbarism'. While Hershfield touches on this in her analysis of the film, my reading more fully brings out the elements of 'civilisation' and 'barbarism' in the characters and story, both as they relate to gender roles and as they apply to the postRevolutionary discourse in Mexico.

The conclusion provides a brief summary of the main conclusions reached throughout the study and suggests that the Golden Age films examined have similarities with recent popular Mexican films. 


\section{CHAPTER 1}

\section{HEGEMONY, MELODRAMA, AND MEXICAN FILM}

Richard Dyer defines hegemony as 'the expression of the interests and world-views of a particular social group or class so expressed as to pass for the interest and worldviews of the whole of society' (1993, 2002: 70). The development and growth of film and other mass media in the twentieth century have long been associated with the maintenance of hegemony (Gottdiener 1985: 997). In criticism on Mexican cinema, scholars have often established a clear link between cinematic melodrama and hegemony. Ana M. López refers to 'melodramatic impulses': historical periods during which melodrama is prolific and which 'exist as specific manifestations imbedded in specific histories and social moments' (1991: 597). Christine Gledhill argues that Mexican film melodrama, despite or perhaps because of its ties to an atavistic past, was a way for the Mexican government and educated Mexicans to further erode the importance of the Sacred in postRevolutionary Mexico, paradoxically by tapping into the traditional elements of the popular audiences (1987: 32). Monsiváis writes that cinema is not just entertainment but also an extraordinary agent of secularisation (1994b: 74). Because of this, John Cawelti believes that there is an attempt 'to reconcile the increasing conflict between traditional Christian views of the world and the secular values of a rapidly changing society' (1991: $39)^{3}$

This chapter examines the concepts of hegemony and popular resistance in mass culture with a particular focus on mid-twentieth century Mexican cinema. It looks at the general history of melodrama, the approaches to the 'culture industry' in Latin America, and how Mexican film melodrama can be seen as an instrument of the state as well as a form of counter-hegemony. The main purpose of the analysis is to provide some of the theoretical bases that will underpin the discussion of several Mexican Golden Age films throughout the rest of the study.

\section{$\underline{\text { History of Melodrama and Outline of Its Main Features }}$}

To understand the significance of melodrama in Mexican Golden Age cinema, a brief outline of the history and most outstanding features of this genre is required. The origins of melodrama can be traced back hundreds of years in European cultural history. As Jesús Martín-Barbero explains, one particular development that played a key role in the evolution of the genre was the shift towards a more visual style of oral storytelling in the

\footnotetext{
${ }^{3}$ See also Brown 2010: 111-112.
} 
shows of itinerant popular fairs in seventeenth-century Europe. This shift occurred as a response to the fact that at one point in the 1600s the authorities prohibited dialogue during these shows, wary of the potential of this type of popular theatre to supposedly corrupt the official, 'legitimate' drama traditions of the upper classes. The prohibition led the show's actors and producers to look for other forms of expression that included the use of mime, sound effects, and song. Significantly, the practice of using music in order to heighten dramatic intensity — which would later become a fundamental component of modern audio-visual narrative forms, such as radio, television serials, and film-also originates from this particular episode in European cultural history (Martín-Barbero 1993: $112,114,116)$.

In his pioneering work on melodrama, Brooks describes the genre as 'the principal mode for uncovering, demonstrating, and making operative the essential moral universe in a post-sacred era'. He explains that melodrama often seems to be most popular when a society has gone through a traumatic experience that has questioned traditional ideas (1976: 15). It is thus not surprising, that a key historical event in the development of melodrama should have been the French Revolution (1789-1799). During this period, the popular sectors would put on plays to comment on the upheaval of the times, thus working through their experiences and demonstrating their awareness of the situation (MartínBarbero 1993: 112). According to the French philosopher Pierre Reboul, these performances directly reflected the worldview of the popular sectors (as cited in MartínBarbero 1993: 113). Juliet John writes that 'melodrama's emergence [...] encapsulates the struggle of the lower classes to attain agency and representation' and she characterises early stage melodrama as 'a site of struggle for cultural and political power' (2001: 34). While popular theatre was a kind of public 'festival' that threatened the hegemony of the ruling classes, the upper-class theatre of the elites was more literary and guarded in its expression of emotion (John 2001: 35, Martín-Barbero 1993: 113-114). As will be maintained in other parts of the present study, Mexican melodrama retains some of these suggestive elements.

As the above outline of its history already indicates, melodrama is specifically related to the visual. Referring to the popular melodramatic performances that took place before the twentieth century, Martín-Barbero asserts that 'words were of much less importance than the optical and mechanical tricks' (1993: 114). This is one of the reasons why melodrama became a major feature of many silent films in the early days of cinema, when intertitles were the only option for dialogue and the focus was forced onto the visual 
(Belton 2009: 142). ${ }^{4}$ For example, Georges Méliès, the innovative French filmmaker experimenting in the late 1800s and early 1900s, incorporated what he had learned as a magician to create visual tricks, astounding audiences with how he manipulated the film strips to include special effects that added to the spectacle of visual story-telling (Cherchi Usai 2011: 27). Early silent film determined the key role that the classic melodrama of the popular theatre tradition played in film and theatre throughout the rest of the twentieth century. Melodrama probably enjoyed the most popularity in the middle of the twentieth century, as the mass media discovered the benefits of using the melodramatic visual techniques that French popular-theatre writers and producers had invented centuries before. Melodramatic films were most common during the 1930s, 1940s, and 1950s in the cinema of many countries. These decades are also considered to be the golden age of cinema for countries such as the United States, France, and Mexico.

One of the most common characteristics of melodramatic works is their Manichaeistic tendency to clearly identify characters, situations, and beliefs as either good or bad. As Matthew Bush explains, 'things are never quite as simple as they seem, yet, through melodrama, every attempt is made to present a world in stark black and white contrast' (2014: 17). Monsiváis notes that in melodrama 'todo es como es y como se presenta: la bondad, la indefensión, la canallez, la generosidad comunitaria, el enamoramiento, la vocación del mal' (1994a: 148). As Bush, Monsiváis, and other critics acknowledge, depth is lacking in melodramatic representations. Characters serve as archetypes, often lacking complexity for the sake of maintaining unequivocal opposites. Manichaeism helps to make melodrama predictable and repetitive and it is a sign of its reliance on an underlying moral code which demands that light triumph over darkness.

A related characteristic of melodramatic works is their tendency to be didactic. Melodrama takes the moral high ground on many occasions, although frequently in principle rather than in practice, and instructs the audience or readers about what is the appropriate or correct way of living. It places great emphasis on discovering the truth of a situation. Didacticism is closely linked to the Manichaean nature of the genre: its characters, actions, and ideas are either right or wrong and the audience or reader are therefore clearly instructed on how to make moral judgements about them. For example, as Monsiváis remarks, in melodramatic narratives priests are often on hand to hear confessions which demonstrate that succumbing to vice is fatal. Also, the traditional family structure is rarely found wanting (Monsiváis 1993: 144). Therefore melodrama

\footnotetext{
${ }^{4}$ Brooks compares these intertitles to the banners and signs used in stage performances, specifically pantomime, further establishing early cinema's debt to the stage (1976: x).
} 
has a reactionary tendency to look back, rather than forward.

Another common feature of melodrama is what Brooks calls its 'inflated and extravagant expression' (1976: 11). Excess is also a part of other aspects of the genre such as the twists and turns of its plots or its exaggerated acting style. Brooks writes the following:

The desire to express all seems a fundamental characteristic of the melodramatic mode. Nothing is spared because nothing is left unsaid; the characters stand on stage and utter the unspeakable, give voice to their deepest feelings, dramatise through their heightened and polarised words and gestures the whole lesson of their relationship. [...] Life tends, in this fiction, toward ever more concentrated and totally expressive gestures and statements. (1976: 4)

Similarly, Martín-Barbero aptly characterises melodrama as employing 'a rhetoric of excess'. Some of the characteristics of the dramatic style and staging of melodrama that are part of its rhetoric of excess can be appreciated in the following extract from MartínBarbero:

Everything must be extravagantly stated, from the staging which exaggerates the audio and visual contrasts, to the dramatic structure which openly exploits the bathos of quick and sentimental emotional reactions. The acting tries to provoke a constant response in raucous laughter, sobs, sweaty tension and gushy outbursts of identification with the protagonists. (1993: 119)

The genre's rhetoric of excess is particularly noticeable in the considerable amount of crying and open displays of anger that take place in many melodramatic films, as well as in the recurrence of other kinds of emotional eruptions. The figurative over-flowing is often accompanied by a literal, physical over-flow as well-one moment tears are shed, the next the shedding of blood. This excess of emotions is usually accompanied by unfortunate events - the most sensationalist, heart-wrenching moments of life — or, on the other extreme, happy occurrences, where human goodness and faith are reaffirmed (Neale 1986: 12). In the latter cases the emotional response may involve smiling, laughing, singing, or kissing. To add to the emotional rollercoaster ride that is melodrama, sometimes the giddy joy and the plunging sadness occur closely together or they intermingle. This is effectively illustrated by a famous scene from the Mexican film Ustedes, los ricos (1948) that will be analysed later.

The above history of the genre and brief analysis of its characteristics already point to the fact that melodramatic works are marked by an inherent tension between hegemony and subversion or resistance. Manichaeistic representation and didacticism reflect its potential for imparting dominant messages, while its emphasis on excess suggests a 
subversive potential to defy and exceed the restraining boundaries imposed by dominant ideologies. As the next section demonstrates, this tension has given rise to contradictory interpretations of melodrama.

\section{Criticism on Latin American Melodrama: Gramsci and the Frankfurt School}

The Mexican film scholar Aurelio de los Reyes offers his evaluation of why fictional motion pictures in early twentieth-century Mexico, which in their early days were mostly melodramatic, were viewed with suspicion. He writes the following:

From the moment cinema arrived in Mexico, intellectuals linked it to the illustrated press and, following the positivist spirit of the era, to science. In that context, fiction cinema was rejected because of its potential to dupe the public: the cinema was a science and as such should show truths. (1995: 65)

In essence, the elites of the early 1900s believed that cinema must be an accurate reproduction of reality. Intellectuals considered that the inherent problem of cinematic fiction was how easily it could be used to manipulate its audience, particularly because of its visual nature. According to de la Mora, the danger of cinema for such thinkers was that it "can show what should not be seen and articulate what social structures deem should remain unsaid' (2006: xiii). Some of the common characteristics of melodrama were negatively perceived because they could be used to influence and confuse audiences.

This view of melodrama as an instrument of manipulation became a prominent feature of criticism on the genre in Latin America during the latter half of the twentieth century, when Marxist approaches to popular culture and the mass media tended to present these as, essentially, instruments of hegemony. An important influence on the study of popular culture was the thought of Italian Marxist intellectual Antonio Gramsci (1891-1937). His most significant contribution to the study of culture is his concept of hegemony, which he developed while imprisoned in Fascist Italy. In his Prison Notebooks he writes the following:

What we can do [...] is to fix two major superstructural 'levels': the one that can be called 'civil society,' that is the ensemble of organisms commonly called 'private,' and that of 'political society' or 'the State.' These two levels correspond on the one hand to the function of 'hegemony' which the dominant group exercises throughout society and on the other hand to that of 'direct domination' or command exercised through the State and 'juridical' government. (1971: 12)

While Gramsci writes in terms of political and economic considerations, his ideas of hegemony can be taken further to be applied to culture also. Indeed, he notes the following: 
Every State is ethical in so much as one of its most important functions is to raise the great mass of the population to a particular cultural and moral level, a level (or type) which corresponds to the needs of the productive forces for development, and hence to the interests of the ruling classes. The school as a positive educative function, and the courts as a repressive and negative educative function, are the most important State activities in this sense: but, in reality, a multitude of other so-called private initiatives and activities tend to the same end-initiatives and activities which form the apparatus of the political and cultural hegemony of the ruling classes. (1971: 258)

Gramsci's views on culture, as well as those of most members of the Frankfurt School, were shaped to a considerable extent by his concern about the rise of fascism in Italy and Germany. Later, a need to develop a new view of Gramsci was put forward. Alan O'Shea and Bill Schwarz consider Gramsci a problematic figure whose ideas needed to be reimagined:

He had no liking for the Americanised popular culture of his own day, for all the originality of his cultural investigations he was never the slightest bit interested in its modern manifestations like the cinema and radio, he systematically subordinated self to politics, had nothing interesting to say on the symbolic forms of popular cultures or their elements of fantasy, wrote incomprehensibly on psychoanalysis, suffered nervous collapses if subjected for too long to the speediness of city life, and so on: a grizzled old Bolshevik, about as far removed from the dynamics of contemporary popular cultures as one could possibly imagine. (1987: 106)

Critics began to expand Gramsci's concept of hegemony to give more emphasis to the people's role and to highlight the importance of modern forms such as television. As John Storey notes, this interpretation is called Neo-Gramscian cultural theory. In contrast to Gramsci, Storey and other writers find potential for conflict and subversion in popular culture. An example of this approach is Storey's analysis of pop songs' ability to raise public conscience (Storey 2001: 105-106). Storey mentions two other critics who adopt a comparable perspective. One of these is Dick Hebdige, who looks at the ways in which youth subculture resists dominant culture by reformulation. The other one is Stuart Hall, who, like other Birmingham School theorists, focused on the counter-hegemonic potential of readers' or viewers' reception practices (Storey 2001: 105-107). For example, in a paper entitled 'Encoding/Decoding' Hall writes that finding meaning in a work is an unpredictable process, coming to the conclusion that 'decodings do not follow inevitably from encodings' (1980: 28).

According to Martín-Barbero, of all the Frankfurt School theorists Theodor W. Adorno (1903-1969) had the greatest influence in Latin America (1993: 40). Adorno describes mass culture, which he famously referred to as the 'culture industry', as 'an 
organised mania for connecting everything with everything else, a totality of public secrets. Everyone who is informed has his share in the secret [...]' (1991: 72). While Adorno's main concern is how the 'culture industry' manipulates the masses, he also grants some degree of agency to the receiver of mass culture. He observes the following:

People give their approval to mass culture because they know or suspect that this is where they are taught the mores they will surely need as their passport in a monopolised life. [...] They fasten on the culture-masks proffered to them and practise themselves the magic which is already worked upon them. (1991: 80, 82)

In this observation, as well as others, Adorno treats consumers of mass culture as consciously wanting to be indoctrinated into the state's worldview in exchange for feeling part of a group and receiving pleasure from familiarity. ${ }^{5}$ This amounts to acknowledging their agency in the reception of mass culture even if it is only in embracing the dominant ideological meanings conveyed through it. The critic's work also assigns a certain degree of resistance to mass-culture consumers. For instance, he writes that 'only their deep unconscious mistrust, the last residue of the difference between art and empirical reality in the spiritual make-up of the masses explains why they have not, to a person, long since perceived and accepted the world as it is constructed for them by the culture industry' (1991: 91). However, this resistance is very limited, an 'unconscious mistrust' of mass culture and not an active reconstruction of content. The idea that comes through most clearly in Adorno's writing is that mass culture 'integrates its consumers from above' (1991: 85).

Of those associated with the Frankfurt School, the ideas of Walter Benjamin (1892-1940) perhaps come the closest to considering the consumers of popular culture as active constructors of meaning. In one of his most important essays, 'The Work of Art in the Age of Mechanical Reproduction', he focuses on cinema. He notes Georges Duhamel's main issue with film: overpowered by the moving images, a viewer can no longer think, and the film acts as merely a source of distraction. While not fully disagreeing, Benjamin adds the following:

Reception in a state of distraction, which is increasingly noticeable in all fields of art and is symptomatic of profound changes in apperception, finds in the film its true means of exercise. The film with its shock effect meets this mode of reception halfway. The film makes the cult value recede into the background not only by putting the public in the position of the critic, but also by the fact that at the movies this position requires no attention. The public is an examiner, but an absent-minded one. (1968: 240-241)

\footnotetext{
5 Adorno calls listeners of popular music 'forcibly retarded' consumers who 'demand the one dish they have been served' (1991: 41, 45).
} 
Benjamin sees the masses as being engaged in a way that they might not otherwise be if it were not for the mass media. An example he gives is the response to a work by Pablo Picasso to one by Charlie Chaplin: while the masses have a reactionary attitude toward a Picasso painting, they exhibit a progressive attitude towards a Chaplin film (1968: 234). In this way, he turns the ideas of Adorno on their head, suggesting that there are occasions in which popular art, churned out by the 'culture industry', can actually be seen as more progressive than high art.

\section{Approaches to the 'Culture Industry' in Latin America}

In Max Horkheimer and Adorno's work Dialectic of Enlightenment, published in 1947, they express a strong distrust of popular entertainment. In reference to cartoons they write:

In so far as cartoons do any more than accustom the senses to the new tempo, they hammer into every brain the old lesson that continuous friction, the breaking down of all individual resistance, is the condition of life in this society. Donald Duck in the cartoons and the unfortunate in real life get their thrashing so that the audience can learn to take their own punishment. (1972: 138)

While not specifically acknowledging Horkheimer and Adorno, Ariel Dorfman and Armand Mattelart seem to have been influenced by them in their study How to Read Donald Duck, written in response to the political situation in Chile in the early 1970s. Dorfman and Mattelart partly blame Disney comic books for the triumph of the military coup led by General Augusto Pinochet. According to them, Pinochet's regime was not only achieved through military force, but also through the mass media (1975: 9). During the process of political change, the messages and values projected by Disney characters served to instil the dictatorship's bourgeois, capitalist, and reactionary ideology in the Chilean audience. The following excerpt shows the role Dorfman and Mattelart assign to the consumer of popular entertainment:

Disney's social class has moulded the world in a certain clearly defined and functional way which corresponds to its needs. The bourgeois imagination does not ignore this reality, but seizes it, and returns it veneered with innocence, to the consumer. Once it is interpreted as a magical, marvellous paradigm of his own common experience, the reader then can consume his own contradictions in whitewashed form. This permits him to continue viewing and living these conflicts with the innocence and helplessness of a child. He enters the future without having resolved or even understood the problems of the present. (1975: 76; italics in the original)

William Rowe and Vivian Schelling, while acknowledging the value of How to Read Donald Duck's exposition of the covert ideology of the Disney Corporation, take issue 
with the authors' simplification of reception. They write that Dorfman and Mattelart 'seem to assume that the receivers of these images have no choice but to receive them passively, that they have no alternative representations available to them' (1991: 107). Indeed, as the above quotation shows, for Dorfman and Mattelart receivers are helpless and naïve; like children who, bewitched by the escapist nature of the fiction, are unable to do anything but accept its thinly-disguised ideological messages.

An excellent example of how this perception of popular culture and the mass media influenced approaches to melodrama in much Marxist criticism during the 1970s is Enrique Colina and Daniel Díaz Torres's 1978 article 'Ideology of Melodrama in the Old Latin American Cinema'. This was a critique of the melodramatic film that characterised the cinema of Mexico and Argentina from around 1930 to 1960, which they negatively contrasted to the politically and socially committed 'New Latin American Cinema' of the 1960s and 1970s. These Cuban critics believed that fiction should inspire reflection on real-world situations and should contain elements of social commitment. In their critique they list such factors as sentimentality, didacticism, and popularity as reasons for the manipulative nature of melodrama and the lack of critical response to it (1978: 51-61). They considered that melodrama simply offers an 'escape from reality,' inducing Latin American audiences to remain ignorant about or in denial of problems in society at large. Since they wrote their critique, many researchers of Latin American popular culture have taken issue with this characterisation of melodrama. For example, Latin American-popular-culture researcher Ana M. López concludes that critics such as Colina and Díaz Torres

simplistically reproduced an elitist mistrust of mass communication and popular culture and were unable to see in the popularity of melodrama anything but the alienation of a mass audience controlled by the dominant classes' capitalist interests. With little differentiation or attention to the processes of reception and identification, they rejected the melodrama as 'false' communication. (1993: 148)

As the critiques by Rowe and Schelling and López outlined above suggest, it is precisely the complex ways in which popular or mass cultural forms are received by audiences which makes the Marxist view of melodrama problematic. To put it simply, aspects of a film through which its producers intended to convey a particular notion or concept can be reformulated by those who view it in order to produce different meanings. Several theorists question whether the intended message and the received message in forms of popular culture or the mass media can ever really be the same, thus challenging the assumption that meaning can be smoothly transferred from producer to receiver. Instead, they suggest that a process of hermeneutic negotiation occurs. For example, for Beatriz 
Sarlo, popular sectors do not so much 'adapt like robots to the contents of dominant culture, as much as they cut, paste, sew, fragment, and recycle these contents' (2001: 103). Robert C. Allen sheds more light on popular reception in his analysis of soap opera viewing, and his thoughts on how audiences 'read' television serials are also applicable to negotiation of meaning in popular cinema. Allen writes that viewers do not necessarily regard soaps as 'reality,' but [...] tend to rely more on what I have called 'ideological' codes in their decoding; that is, soap opera characters and situations are 'made sense of' by integrating them into the viewer's own field of knowledge, values and experiences. [...] Other viewers tended to project the plotlines according to non-ideological codes: those of narrative expectation, acting conventions, intertextual codes, etc. (Allen 1983: 104105)

A similar perspective has been applied to the field of the Latin American mass media with particularly productive results by Martín-Barbero, for whom melodrama's rhetoric of excess defies dominant cultural assumptions and functions as 'a form of resistance against a particular "economy" of order and polite restraint' (1993: 119). While Martín-Barbero considers that emotional displays in melodrama are likely to be frowned upon by the principled and cautiously guarded middle and upper classes, his analysis does not reduce the lower-classes to emotional excess. This distances his perspective from that of Paul R. Gorman, who sees such displays as an essential element of lower-class life. According to this critic, the popular sectors believe that no emotion should be kept hidden and, instead, feelings should be shared and desires acted upon (1996: 23-24, 44). An even more problematic interpretation of melodrama's emotional excess is Gledhill's claim that the genre seeks to rediscover the emotions that have been repressed by finding emotional freedom in an earlier, less rigid past or in the more 'barbarous' side of human nature (Gledhill 1987: 32). This evokes a Western history of associations between so-called 'primitives' and the working classes. Marianna Torgovnick brings attention to such a history, arguing that in the Western imagination 'frequently, the working class or other subordinated segments of a population become associated or identified with primitives the Irish for example, or Jews, or (more specifically) Eastern European Jews or nonEuropean Jews, or U.S. blacks' (1991: 18).

However, in line with the emphasis that critics like Sarlo and Martín-Barbero place on the counter-hegemonic nature of the genre, it is certainly possible to understand the emotional excesses of the melodrama as potentially subversive in the Latin American context. Excess is inherently uncatholic, often because of its close relation to pleasure. Around the time of the 1940s some Catholic churches in Mexico would advise their parishioners about what specific excesses could be seen in the latest films, such as 
drunkenness, fighting, and sexual temptation, in order to warn them of the corrupting influences of popular cinema (Rubenstein 2001: 217-218). By controlling excess as much as possible, the social order and morality sanctioned by the Catholic Church could be more easily maintained. An example of the lengths that believers were encouraged to go to in order to keep their thoughts and actions free of the sin of excess is a particular social custom that was practised in early twentieth-century Mexico. During sexual intercourse between a married couple, women were encouraged to wear a white sheet with a hole in it. In this way sex was tolerated by the Church because of its necessity for procreation, but kept as free from pleasure, desire, and enjoyment as possible. In such ideological contexts the depiction of excess in melodrama often proved problematic. Melodrama often implies that sex is enjoyable, even if it is performed outside of marriage or in an unfaithful relationship; that drunkenness can make men more honest; that Rulfoesque vengeance can be a valid way of dealing with a problem. The notion that more sex, more drink, more passion, and more worldly pleasures can be advantageous is a clear subversion of Catholic dogma and of conservative beliefs. In light of this consideration it is therefore not surprising that for Gorman the depiction of excess could be liberating for a lower-class audience (1996: 43-44).

\section{Mexican Film Melodrama as an Ideological Instrument of the State}

Jean Franco writes that mass culture 'has clearly a didactic function and operates as a socializing system that is now as powerful as schooling and religion, although its methods are vastly different from the methods of these institutions' (1986: 250). In Franco's view, mass culture aims to reduce heterogeneity in a similar way to how public schooling and organised religion impose a dominant viewpoint. Cinema in Mexico was used by the state to promote its ideology and diffuse social tension. This meant that it often offered a simplistic, homogenising view of the world.

Because the Mexican state emerged from the Mexican Revolution, it frequently portrayed the Revolution in historical melodramas as an event that supported its desired Mexican identity. John Mraz writes the following about the official interpretation surrounding it:

The most pervasive officialist myth of the Mexican Revolution is that this was a prolonged struggled of the Revolutionaries [...] against the dictatorship of Porfirio Díaz (1876-1910) and its counter-revolutionary reincarnation, Victoriano Huerta (1913-1914). Concerned to legitimate the ruling party as sole heir of the founding cataclysm, the official account conflates the Revolutionaries into the same camp, eliding the fact that the differences between these parties were almost as great as those they had with the Díaz-Huerta governments, and that this struggle was defined more 
by the warfare between the Revolutionaries than by the battle of Old and New Orders. (1999)

As Noble notes, the post-Revolutionary state's 'legitimacy was predicated on the state's status as heir to the revolutionary project, whose values it promoted and would carry forward' (2005: 53). The Revolution was used as a uniting event, romanticised as an unambiguous struggle for egalitarianism in Mexico. Noble writes the following:

For the revolution to function within the post-Revolutionary political and cultural imaginary as the desired unifying, foundational narrative of identity, it therefore had to be remembered and thereby reinvented as what it was not: a unified struggle propelled by a set of coherent aims and ideals. (2005: 53)

This 'officialist myth' is important to this study because it is seen in the depiction of the Revolution in the Golden Age films. The Mexican government of the time had its input into the films. Seth Fein writes that 'from the outset of sound film production in Mexico in the early 1930s, Mexico's ruling regime subsidised historical movie making as a source of national socialisation and ideological rationalisation' (2001: 171). It was also able to exert influence on what films would be made and their portrayals of sensitive issues: Franco notes that Las abandonadas (1945) was government-subsidised and that, because of its portrayal of the military, was censured (1986: 256). As Fein documents, 'the role of the state in guiding mass cultural production remained constant' throughout the 1940s and many of the directors seemed enthusiastic to further the cause of the Revolution (2001: 163). The director Emilio Fernández is particularly remembered for linking his historical melodramas, like María Candelaria (1943) and Río Escondido (1948), to the aims of the Mexican Revolution. However, others' contributions, while perhaps tending toward greater subtlety in their presentation of an idealised Mexico, also encouraged a pure vision of Mexico which could promote the image of a unified Mexican 'family'. For example, Ismael Rodríguez co-directed with Álvaro Gálvez y Fuentes the film Mexicanos, al grito de guerra (1943), which starred Pedro Infante as a patriotic soldier during the French invasion of Mexico in the 1800s. He received permission to make it from the Mexican government and, according to Fein, it served 'to legitimize the state's claim to embody the nation' $(2001: 173,181)$.

The Mexican government during the height of the Golden Age was under the guidance of President Manuel Ávila Camacho. His presidency from 1940 to 1946 indicated a subtle change in achieving the aims of the Revolution. Daniel Newcomer notes the following:

Ávila Camacho's inaugural address demonstrates that there existed a notion of continuing revolution during the 1940s. [...] It seemed that the 
mechanism of revolution would 'switch gears' in an effort to perfect the achievements brought about in its name. A transition from revolution to evolution would supposedly emerge. (2004: 3)

One of the major changes, not in keeping with the secularism of the Revolution, was the softening of the government's stance on religion. Berg notes that religion in Mexico has always been contentious and its place in Mexican society fraught with contradictions. He argues the following:

The church is accepted as Christ's institutional representative on earth. At the same time it is resented because of its association with the Spanish Conquest, the oppression of colonial rule, and the postcolonial ruling-class power structure. (1992: 27)

The state's disdain for the Church reached new heights in the 1920s and 1930s, as evidenced by the earlier mentioned Cristeros Rebellion (1926-1929). However, the 1940s saw a change in government policy. Fein notes that Ávila Camacho abandoned anticlericalism, which was 'central to the revolution's ideology and postrevolutionary state's policies during the preceding Calles and Cárdenas epochs', due to the president's professed Catholicism (2001: 181). Newcomer suggests that this change in policy was because of 'a growing elitism among revolutionaries who had benefitted from the new social hierarchy that the upheaval had created and now openly admitted their conservatism' (2004: 3-4). Carl J. Mora writes that the return to religion 'was exactly the message that the country's fretful middle classes had been hoping for' (1982: 52). Therefore the films, while carrying on the stated aims of the Revolution, often incorporate religious elements and thus find themselves aligning with the Cristeros rather than the government of Plutarco Elías Calles (1924-1928) in this respect.

Berg lists the different elements of a national ideology that he observes in Mexican Golden Age films, which he notes are all in the state's interest. In addition to the conflicted attitude toward religion, he also notes that capitalism 'is the quintessential villain of every Mexican narrative', patriarchy is bolstered by machismo, and the films strongly suggest 'authentic mexicanidad resides in the lower class' (1992: 22-25). According to Berg, other frequent themes are internal migration (and emigration to the U.S.) and an ambiguous attitude to history. These reoccurring elements are also referred to and expanded upon in other important research into Mexican Golden Age cinema, as will be shown later, but for now the significant point is that many critics emphasise the alignment of the worldview of most Golden Age films with the aims of the post-Revolution Mexican state. It is very important to also bear in mind that most of the popular artists involved in Mexican cinema were consciously working within the Mexican state's nationalist project. 


\section{Mexican Film Melodrama as a Form of Counter-Hegemony and Subversion}

As opposed to the above critics' emphasis on Mexican film melodrama as a tool of ideological domination by the state, it is evident that this type of cinema functioned not only as a vehicle of hegemonic ideals but also as a medium that could be used by viewers in different ways. Instead of merely indoctrinating audiences, melodrama offers a potential for viewers to work with some of the elements and use them to counterhegemonic effect. As Bush writes, Latin American melodrama is 'a malleable structure that is adapted and readapted so as to provide a means of comprehending social change across narrative genres' (2014: 17). Melodrama is a way of processing human existence and, as Julianne Burton-Carvajal writes, it serves as a vehicle for 'registering experience and [...] understanding both individual and collective placement in the universe, a means of encoding moral and ideological concerns within registers of the aesthetic and the emotional' (1997: 190). To simplify this definition, melodrama validates lived experience and emotions, not only those felt on a personal level but also-and perhaps more importantly - those shared by a group. Therefore, melodrama can be seen as a way for audiences to cope with or process reality, not necessarily to escape from it. Monsiváis writes that Latin American audiences 'for a long period [...] considered films to be neither art nor spectacle but rather the continuation of everyday life, the believable explanation of the meaning of their lives' (1993: 142). Thus, for Monsiváis, audiences do not use melodrama as escapist entertainment that allows them to take a break from life but, rather, they incorporate it into their reality. ${ }^{6}$

Monsiváis has written much about Mexican cinema's relationship to modernity. For Elena Poniatowska his contribution is 'one of the clearest examples of the argument that popular culture constitutes the essential motor of transformation and permanence' (2001: xii). According to Monsiváis, in the cinema 'farewells were said with ringing rhetoric and false sorrow to the traditions that no longer had a place, and there the new ones demanded by the selective and partial modernisation of the country were greeted with laughter and verbal abuse' (1993: 144). He also writes that 'gracias a la industria nacional, es el chance que tiene el Pueblo de recibir la educación [...] fundamental' (2008: 83-84). Therefore one of Monsiváis's main arguments is that Golden Age films taught audiences about the modernity that they were experiencing. The viewers, many of whom were coping with rapid change, saw in the films characters and plots which both reflected

\footnotetext{
${ }^{6}$ For a similar argument, see Landy 1991: 16. Leland Ryken also makes a similar point in relation to fiction in general (1991: 16).
} 
and shaped their own experience and understanding. Monsiváis writes the following:

In the cinema, they learned some of the keys to modern life. The modernisation presented in films was superficial, but what was seen helped the audience to understand the changes that affected them; the destruction or abandonment of agricultural life, the decline of customs once considered eternal, the oppressions that come with industrialisation. (1993: 143)

According to Monsiváis, the creation of a national identity was not strictly prescribed by the films themselves. One of his persistent claims is that audiences engaged in making the films meaningful to them:

If run-of-the-mill actors, stars, set designers, directors and cameramen invented a country also called Mexico, they did it in collaboration with those who, in the stalls of theatres or the hard seats of rural cinemas, recuperated and remade the events they saw on the screen and transformed them into myths, enjoyment, family culture and, on more than a few occasions, into artistic emotion. (1993: 146)

Rowe and Schelling also emphasise the importance of the films for the Mexican audience, writing that 'the images may have been in many ways vulgar and debased-for instance exalting machismo- - but the masses celebrated in and through them their new social presence' (1991: 232). The interplay between the film and its audience is, as with Monsiváis's earlier research, a significant consideration for Noble. She concludes that “"México moderno" does not exist as an object, but instead as a relationship: "México moderno" [...] resides in the relay of looks between the screen and the spectator' (2005: 91).

\section{Conclusion}

The above analysis has highlighted the ambivalence inherent to melodrama: while the genre's emphasis on emotion and excess can be seen as a subversion of the dominant ideologies, it is also a potential tool for the ruling elites to manipulate the popular sectors into conforming to beliefs and practices that they deem acceptable. This ambivalence is one of the key characteristics of melodrama that will be explored in relation to films from the Golden Age of Mexican cinema throughout the rest of this study. 


\section{CHAPTER 2}

\section{CRYING, SUFFERING, AND THE CONTAINMENT OF SOCIAL TENSIONS IN THE NOSOTROS LOS POBRES TRILOGY}

One of the most enduring melodramatic films from Mexico's Golden Age of Cinema is Nosotros los pobres, directed by Ismael Rodríguez. This 1948 urban melodrama was highly successful at the Mexican box office, and is described by Monsiváis as constituting 'la cúspide del melodrama' and 'un recuerdo colectivo' (1994a: 144). Its commercial triumph led to Rodríguez directing two sequels, Ustedes, los ricos (1948) and Pepe el Toro (1953). As these films are classic examples of Mexican melodrama, they readily lend themselves to an analysis of the ways in which key elements of the genre- such as excess and didacticism - are simultaneously incorporated into a melodramatic film. They also demonstrate how melodrama was used as an ideological tool in order to facilitate Mexicans' transition to a new socio-political order.

Building upon the existing body of critical work, the following analysis explores the manner in which the films could be seen to fulfil the role of promoting modernity, particularly focusing on their employment of melodramatic elements. After summarising the plots of the films and the perspectives of important critics, this chapter looks at the films' construction of a sense of community for the poor in an urban context, which could be seen to assuage widespread worries about the disintegration of communities because of modernisation and urbanisation. Then, it assesses the films' representation of the urban poor as deeply connected to their emotions and inner feelings, in sharp contrast to the bourgeoisie. Finally, it examines the treatment of the notions of chance and misfortune in the trilogy. Overall, the analysis concords with the extant criticism in that there is a clear intention behind the Nosotros los pobres trilogy to keep social tensions under control.

\section{Plot Synopses and Review of Existing Criticism}

Nosotros los pobres has a convoluted storyline, filled with a large number of characters who are chiefly archetypes, as is made clear by many of them being billed as 'La romántica' or 'El mujeriego' in the film's credits. The main character is Pepe el Toro, a lower-class carpenter who lives with his niece Chachita. Pepe has brought Chachita up and told her that he is her father. In reality, she is the daughter of Pepe's sister, a prostitute whom Pepe blames for causing Chachita's grandmother to become both paralysed and mute. Chachita's grandmother is eventually killed by a marihuana addict, who has taken her and Chachita into his house after Pepe is unjustly arrested and all of their possessions 
are taken away. There is, however, somewhat of a happy ending as Pepe escapes from jail, marries his faithful but unfortunate sweetheart, and has a son. Chachita's story in particular has a bittersweet ending, as she discovers the identity of her mother who is on her deathbed.

The next two instalments of the trilogy feature the same characters. In Ustedes, los ricos Chachita is approached by her rich father who wants her to become part of his family. She is tempted to accept his offer after his mother uses her wealth to almost destroy Pepe's business, but in the end she is unable to betray her friends and family. Meanwhile, Pepe finds himself fighting a villain and his henchmen whom he encountered in Nosotros los pobres. One of them starts a fire at his workshop, which injures Chachita and kills her father and Pepe's son. Ustedes, los ricos ends with all the poor people celebrating Chachita's birthday, as her bereaved paternal grandmother joins their happy festivity. In Pepe el Toro, which Monsiváis calls 'un fracaso irremediable' (2008: 254), Pepe becomes a boxer in order to raise money after his carpentry shop is closed. Unfortunate events in this final film include Chachita losing all of her father's inheritance and Pepe accidentally killing his best friend in the ring.

Due to the extraordinary success and the lasting legacy of these films, most major critics of Mexican cinema have provided elucidative commentary on them. Jorge Ayala Blanco writes about the first film in a somewhat disparaging tone, particularly taking issue with the lack of realism that the film itself claims to have captured in its 'frases crudas, expresiones descarnadas, situaciones audaces'. According to him, 'es un melodrama reñido con la realidad que pretende reflejar' and 'el impulso antirrealista de la primera secuencia nunca se pierde' (1993: 98-99). However, Ayala Blanco also praises the film because he considers that it 'rescata y compromete históricamente la sensibilidad popular en una etapa de su devenir' (1993: 101). He also argues that the film's treatment of violence predates American films like The Set-Up (1949).

Monsiváis also discusses the trilogy, particularly emphasising the star of the series Pedro Infante and the films' role in promoting modernity. He writes that 'Ismael Rodríguez y sus guionistas exaltan expresiones, personajes y escenas melodramáticas' and 'los conflictos y los desgarramientos [...] refrendan la naturaleza del melodrama-ala-mexicana: para que el público no se sienta tan agobiado dénsele anécdotas del agobio total' (1994a: 144, 148). He concludes that 'en la perdurabilidad de la trilogía [...] actúa la sustitución de una conciencia de clase por un entreveramiento de rencor social y chantaje sentimental' (1994a: 152). As can be appreciated, from Monsiváis's perspective these films served as a means for the Mexican government to glorify poverty in order to 
keep the poor in their place, which is ironic in view of the Mexican Revolution's supposedly leftist political agenda.

Anne T. Doremus also uses the example of Pepe el Toro to put forward similar interpretations. She writes that Nosotros los pobres is the most egregious example of the romanticisation of poverty from this time period, pleasing its audience through its flattering depiction of the lower class while at the same time aiding the government in its promotion of nationalism. Doremus writes of an 'implicit pact between many filmmakers, the state and film viewers', with popular urban melodramas like Nosotros los pobres strongly supporting the myth of the Mexican state (2001: 180). She also writes the following:

Many Mexican artists and intellectuals from 1929 to 1952 constructed archetypes of the poor in order to convey particular ideas about the national identity. These archetypes reflected the values, biases, fears and desires of their creators and promoters, and were used to control and repress the underprivileged while empowering both the state and the privileged classes. (2001: 7)

Doremus considers the film as a kind of manual for how to adapt to urban modernity, writing that it 'aspired to shape the behaviours and attitudes of the poor' by emphasising traits 'that would be important in avoiding the social disintegration that could result from immigrants' sudden contact with so-called modern society' (2001: 172-176).

This is also Carmen de la Peza's finding. She writes that 'el melodrama Nosotros los pobres, como la pornografía, es obsceno; no oculta nada, presenta descarada y descarnadamente los deseos inconfesados y el rostro degradado de una sociedad misógina, moralista, donde la injusticia y la opresión se justifican por el heroísmo de la pobreza' (1998: 59). De la Peza writes the following about the film's depiction of the poor:

'El pueblo' [...] se convierte en protagonista mistificado y reinterpretado de manera que todas las aristas subversivas y críticas de la realidad de la pobreza nacional quedan borradas, mostrando sólo el espectáculo estereotipado y folclórico de la miseria urbana. (1998: 57-58)

As many of these critical contributions suggest, the trilogy's tendency to glorify the lower classes in order to camouflage social inequalities was part of the Mexican Revolution's imperative to facilitate the transition to an urban modernity for lower-class rural Mexicans, who tended to be deeply attached to traditional values, such as the idea of the family and religion. 
The Nosotros los pobres films take place in an urban close-knit community, or vecindad.

Gustavo García writes the following about the vecindad:

Since the $19^{\text {th }}$ century, some old Spanish mansions were divided into small flats for the poor. The vecindad was such a mansion in ruins, partitioned and inhabited by a heterogeneous community. It was the space of solidarity, of the working people, of the poor but honourable; it was the space one left to climb the social ladder only to return, repentant, to one's roots and to the warmth that could not be found among the bourgeoisie. (1995: 156-157)

In this quotation García refers to perhaps the most important aspect of the bourgeois attitude toward the poor in the cities: that upward mobility was not to be encouraged. Chachita's predicament certainly conveys this message, as she resists falling into the trap of becoming a part of the bourgeoisie by entering her biological father's family. Accordingly, in these films, working class neighbourhoods were highly idealised. The creation of a space of community in the cities links in with the Revolution's need to make the poor feel they are part of a community and reflects a conception of national identity on the part of the creators of the images. With the large migration of Mexicans from the rural areas to the city in the 1940s, the ex-peasants needed reassurance that this relocation did not mean that they had to abandon traditional values like community and Catholicism. Cities have historically been associated with vice (Williams 1973: 1). The city has nightclubs and brothels and is thus closely linked with noise, sensuality, and sin. Referring to the early 1950s Mexico, Rubenstein writes the following:

Complaints about vice, crime, and corruption frequently shaded over into complaints against mass media or popular culture. Brothels often called themselves dance halls, and some commercial institutions confused the matter even further by combining the two functions. [...] Citizens might complain about Mexico's cities because of two spatial juxtapositions in them: first, the overlap of moral categories (home/whorehouse, or policeman/thief), and second, the overlap of sonic categories (music/noise, decent talk/foul language, or uproar/peace). (2001: 222-223)

The films that make up the Nosotros los pobres trilogy show how families can survive with their morals intact despite living in an urban environment. This atmosphere contains temptations like drugs, corruption, and prostitution. Weaker characters living in the vecindad of Nosotros los pobres fall prey to these snares. For example, Don Pilar, Celia's father, is addicted to marijuana, which leads to him stealing and physically abusing others, and Yolanda, Pepe's sister, is a prostitute who serves as a reminder of the city's dark corners. However, immoral characters like Don Pilar and Yolanda are the exception; most of the characters in the film manage to thrive morally in the urban environment. Pepe and his friends rarely even smoke, much less associate themselves 
with mind-altering drugs. They also provide an example of model sexual conduct. Pepe resists the sexual advances of women who seem to throw themselves at him, both before and after his marriage to Celia. De la Peza calls the couple, who sing the romantic song 'Amorcito corazón' several times throughout the trilogy, the 'arquetipo de la pareja ideal en el cine nacional' (1998: 19). In addition, significant time in Pepe el Toro is given to a subplot about Chachita's struggle to save her first kiss for her wedding in order to please her father. ${ }^{7}$

De la Peza believes that Nosotros los pobres's 'exaltación de los conflictos familiares borra los conflictos y las contradicciones sociales' (1998: 58). Therefore, the city is shown as not so much corrupting people as exploiting their pre-existing weaknesses in character. Even though Yolanda compromises the family unit by being sexually promiscuous and being an unfit mother, family connections can still be kept alive in the urban environment.

\section{The Exaltation of the Poor's Emotions to Compensate for Their Poverty}

In addition to the idealisation of the urban community and family, another way in which these films can be seen to contain social tensions is by celebrating the poor as emotionally superior to the rich. Colina and Díaz Torres write the following about the abundance of sentimentality in the Old Latin American Cinema:

The petty bourgeois vision found the most suitable means for harmonizing its fear, as a class, with the demands of reality in the manipulation of the emotions and in their over-valorisation. Sentimentality was used as a means of escape from that chaos of social conflict. (1978: 51)

Several critics argue that this appeal to base feelings creates an irrational, over-powering effect on audiences, similar to the effect of pornography on viewers. For instance, Colina and Díaz Torres call the plots of Latin American melodrama 'erotic quasi-pornography' (1978: 55) and Linda Williams sees melodrama's 'gender- and sex-linked pathos' formula as carefully constructed for mental and emotional manipulation as pornography is (1991: 3). As already noted, de la Peza calls Nosotros los pobres itself obscene (1998: 59). García writes that Rodríguez's 'melodramas shamelessly strove to manipulate the most elemental levels of emotion in the spectators' (1995: 161). In doing this, his films create an emotional investment in their characters and messages. In Nosotros los pobres the emphasis is on the poor's feelings, who live life more honestly and openly than the rich. In Rodríguez's fictional world, they live gratifying lives. In fact, they may experience

\footnotetext{
${ }^{7}$ These representations are connected to Catholicism, sometimes explicitly and other times by implication.
} 
greater fulfilment because they are in touch with their emotions.

There are many scenes in the trilogy, always underscored by unsubtle music, in which characters exhibit strong emotions. One of the most heart-wrenching ones awkwardly combines deeply-felt happiness with an all-consuming sadness. This is in keeping with Monsiváis's assertion that in Rodríguez's work, 'es muy extrema o extremosa la relación entre lo trágico y lo cómico' (2008: 158; italics in the original). In this famous scene from Ustedes, los ricos, Pepe's young son has just died in a fire, driving him and his wife to depression. After the tragedy, Pepe is shown alone holding his dead son. At first he looks around, as if he were unsure how to feel. Then, as his eyes rest on the hearth where his son used to bring joy to everyone in the house, he thinks back on the happy memories of him and he smiles. His smile gives way to laughter, starting quietly before increasing in loudness. As he laughs, he looks down at his dead son's face and his laugh becomes an uncontrollable sob, sounding as if he is in pain. When the viewer thinks Pepe might be calming down, he looks at his son again and lets out another cry of anguish. For some viewers, Pepe's behaviour may be unacceptable, as, even though he has locked himself inside his house, his sobbing can be heard by all the neighbours. Burdening everyone around him with his suffering could be considered inconsiderate and undignified. However, in the worldview of the film this is not the case. His openness in exhibiting his feelings instead allows the community to become closer through the shared experiences. Pepe's behaviour after the tragedy is juxtaposed with that of Doña Charito, 'la millonaria', whose higher social status prohibits her from unreservedly grieving over her own loss. This contrast underlines the class expectations: Pepe can indulge and express his emotions because he belongs to the lower class; Doña Charito cannot because having an ample amount of money means that a certain standard of behaviour is assumed of her, including sobriety of emotion.

Miriam Haddu writes that 'Nosotros los pobres attempts to convince its audience that poverty equals benevolence and that in order to be a good Mexican one had to be poor' (2007: 124-125). Doremus also notes that Mexican filmmakers portrayed the poor as heroes, doing this in order to promote nationalistic goals (2001: 180). Therefore, the use of sentimentality and exaltation of the lower classes made the poor feel good while supporting the interests of the Revolutionary state to pretend that there is no real social conflict (Colina and Díaz Torres 1978: 51). Both Nosotros los pobres and Ustedes, los ricos contain examples of selfish wealthy characters who realise that the poor are morally superior. The wealthy Licenciado Montes spends the duration of the first film trying to employ Pepe's girlfriend Celia as his secretary (and, by implication, have her be his 
mistress). She eventually takes the position in order to help Pepe when he is in jail. When Montes discovers that Celia is devoted to Pepe and will not be 'bought' he has a sort of epiphany and tells her the following:

¡El amor! Nunca he creído en él. Yo siempre he tenido que pagar. Pero ahora veo que es algo real, sincero. [...] El amor sí existe. Y ustedes los pobres son felices, porque tienen amor.

This final sentence is possibly the key line of the film, concisely summing up its message. The film suggests that poor people are happier than those with money because they possess and value love. Montes does not believe in love that is not bought until Celia shows him that it does exist, because she is pure in her affection towards Pepe and does not want anything out of the relationship for herself. For example, when Montes invites Celia to take whatever money she wants from his wallet, she responds, 'Lo único que quiero es salvar a mi Pepe'. The poor have determination and will not be corrupted by the temptation of money, because love always triumphs over money for them. As Doremus notes, such scenes 'portrayed the rich as unhappy and unscrupulous' and 'sent the message that the poor are better off than the rich because they understand and experience true love' (2001: 176).

In the films it never appears to be a possibility that wealth and happiness could go together. Indeed, the rich are shown as seeking or in need of the depth of feeling and authenticity that only the poor possess. Ustedes, los ricos introduces a number of rich characters who seem to do little more than while away their time in a mansion-like house. One of those characters is Chachita's father Manuel de la Colina y Bárcena, who dies in a fire while saving his daughter. After his death, Manuel's wealthy mother, Doña Charito 'la millonaria', realises that all of her friends and relatives have only come to the funeral because they hope to receive money from her once she has died. Deserted by all her rich 'friends', she eventually finds the courage to approach the poor people, who are having a lively birthday celebration for Chachita. The following exchange takes place:

Doña Charito: Por favor, déjenme entrar. Estoy muy sola con todos mis millones y vengo a pedirles, por caridad, un rinconcito en su corazón. Ustedes que son valientes y que pueden soportar todas sus desgracias porque están unidos. Ustedes los pobres que tiene un corazón tan grande para todo. Denme de él un pedacito. Ustedes son buenos. [...]

Pepe: Pásele, señora. Ahora no entra uste' con los pesos por delante. Entró con una pena y el corazón en la mano. 'Ora sí es de los nuestros. Aquí entre nosotros encontrará lo que nunca ha podido comprar. Lo que más vale. Amistad [y] cariño.

After her condescending attitude toward the poor throughout the film, Doña Charito is humbled by seeing the flagrant inauthenticity within her circle of friends and relatives. 
She realises that true happiness is found when people are clearly not corrupted by the love of money. 'La millonaria' finds acceptance within a community where Pepe assures her she 'encontrará lo que nunca ha podido comprar'.

As these examples show, the films suggest that wealth leads to an environment of mistrust and relationships built on greed. On the other hand, the poor seem to find it easier to retain a sense of morality, as they unsullied by money and power and live life more openly. As Doremus notes, in urban melodramas like these 'the protagonist may not get ahead, but he (and the audience) could take comfort in his inherent goodness' and while 'this figure suffered from adverse socioeconomic conditions' he 'always maintained his integrity' (2001: 172). Indeed, the films' creation of a working-class hero in the character of Pepe, who finds fulfilment where he has been placed in life despite his struggles, is a convincing endorsement of being satisfied with the status quo.

\section{Chance as the Defining Force in the Characters' Lives}

The film series also encourages the status quo by its emphasis on chance, which is shown as a natural part of life. This portrayal conceals any responsibility that the government and the upper classes may have for the suffering of the lower classes. There is a strong element of surprise in these three films, as secrets are revealed and events become increasingly dramatic. Many of these moments that are designed to surprise and move audiences involve the characters suffering misfortune and going through adverse and challenging circumstances.

The attitude toward chance in Nosotros los pobres ties into the idealisation of the poor's situation in the cities. As should be clear by this point, the characters are surrounded by misfortune, especially Pepe and Chachita. For Jorge G. Castañeda Pepe 'is the victim par excellence, who takes his fate with dignity and stoicism' and 'is largely resigned to his fate, as the films' titles suggest' (2011: 96). Pepe refers to chance as 'la mala suerte que me persigue'. This personifies it as a deliberate force in his life, as it would appear to be for any typical poor person. While some of the difficulties that are suffered by the poor are due to societal problems, such as an inadequate justice system, the films tend to suggest that God or chance are to blame for the characters' misfortunes.

The character of Carmellito 'el jorobado' in Nosotros los pobres explains the philosophy that undergirds melodrama: problems are never far away in this imperfect world; therefore, protagonists must resign themselves to what surrounds them, seeing it as fate or destiny and supporting one another in the trials of life. As Chachita cries over doubts surrounding her mother, he tells her the following: 
Si el buen Dios se la quiso llevar a los Santos Cielos sólo Él sabe por qué lo hizo, y no hay que alebrestarse. Porque ella te está licando desde la Gloria y si ve que sufres, pos ella también se pone triste. Dichosos los ojos que pueden chillar. Porque cuando se tiene seco el llanto te quema el corazón. [...] Llore porque éste es un valle de lágrimas. Llore porque su tristeza es llanto y Diosito dice: 'Bienaventurados los que lloran porque ellos serán consolados'.

It is not without significance that Carmellito connects crying and sobbing to a purging spiritual experience. As the verse he quotes implies, those who feel sorry for their situation have a closer connection to God.

In Carmellito's consolation to Chachita, he attributes the source of her suffering, and, by implication, the misfortunes of her fellow lower-class city dwellers, to God. This has the same effect as blaming Fate for troubles and unexpected deaths, as both are impersonal (or personalised) forces whose actions cannot be questioned by uneducated people. In the world these characters inhabit, it appears to be useless to truly question adversity, because no answer is possible. Although they may mention God's will, there are no answers that make sense. This is because they do not consider the role of visible entities such as the government in determining their situations, as doing so would compromise the films' commitment to the promotion of urban migration. As Doremus and Monsiváis have argued, Nosotros los pobres elevates the belief that in order for the lower classes to successfully integrate themselves into the post-Revolutionary world of modernisation, they must resign themselves to what Fate or God has supposedly determined for them. The idea that God and fate are responsible for the poor characters' social predicament takes away the responsibility from the Mexican state (Doremus 2000: 36). The film ends by telling the viewer that 'se sufre, pero se aprende'. This implies that suffering is necessary for learning and is part of a divine will. Coping with the invisible but influential 'character' of Fate makes the poor stronger and better connected, at least in the mythology encouraged by this series of films. There is comfort to be found in this way of thinking in a society recently torn apart by violence, where the lower-class citizens were struggling to make sense of a new world.

\section{Conclusion}

These comforting messages of the Nosotros los pobres trilogy suggest an attempt by the creators of the films to keep social tensions under control. Similarly, reassuring messages that encourage looking to the past may have an ulterior motive. The ending of Nosotros los pobres sees the characters putting the past to rest. While there are elements that suggest a promising future, such as Pepe's marriage and newborn son, Chachita's happy 
ending involves looking to the past: Chachita is glad that she has her mother's grave to visit now that her ignorant view of the past has been corrected. Chachita does not simply move on with her life despite not knowing who her mother is; she fights to find out and resolve her past, to understand it and remember it. She cannot progress forward without her past. This idea of looking to the future while holding on to the past can be seen as a way to lead traditional Mexicans who felt connected with the pre-Revolution past towards a post-Revolution future. 


\section{CHAPTER 3}

\section{MATERNITY, FAMILY, AND RELIGION IN CUANDO LOS HIJOS SE VAN}

According to Julia Tuñón, the concept of the Holy Family was at the core of many Mexican films of this period (1998: 123). The representation of the family in the 1941 film Cuando los hijos se van, directed by Juan Bustillo Oro, seems at first sight to support the view of a 'Sagrada Familia'. According to most critics, the film does not offer possibilities of negotiation in the face of social transformation, but rather serves as a strong advocate of traditional Catholic values. Indeed, this film has been examined as a maternal or family melodrama, an old-fashioned motion picture that glorifies the selfdenying mother. Particular attention is often given to the character played by Sara García, who played similar maternal figures in most of her roles. Monsiváis treats the film as an emotional melodrama most notable for its fetishisation of the mother and its ability to encourage wayward children to come back home (1994a: 125-128). The film has also been examined as a heavy-handed defence of tradition. Mora's brief analysis dismisses the film as 'a regressive idealisation of traditional values' which provided escape from 'not only the changes that Mexico was undergoing but the unsettling Axis victories and the radically altered world order that they portended' (1982: 56). Berg treats the work as obvious, painfully deliberate, and only notable because 'it contains in bud or in blossom all the themes that play themselves out in Mexican cinema and that, taken together, encompass the major tenets of Mexican ideology' (1992: 17).

While Cuando los hijos se van lends itself to being analysed from these perspectives, there are certain elements of the film that suggest the more progressive attitude that Mexicans needed in order to adapt to the onset of the modern world after the Mexican Revolution. In Mexican cinema of the 1940s, melodramatic encounters within the family can represent processes of conflict and negotiation that Mexicans were forced to experience in the face of social and political transformations of the time (Joseph, Rubenstein, and Zolov 2001: 7-8). This chapter will explore the presence of both the ideologically regressive qualities and the potential avenues for progress in Cuando los hijos se van's fictional family. The idea of contrasting forces within the family supports Monsiváis's view that new forms of entertainment such as film in the Mexican context mediate 'between the shock of industrialisation and the rural and urban experience which has not been prepared in any way for this giant change, a process that from the 40s modifies the idea of the nation' (1995a: 151).

The first part of this chapter fleshes out the film's allegiance to a conservative 
Catholic worldview, expanding upon the work of previous critics and examining the characters' religious symbolism. Similarly, it analyses the portrayal of the negative effects of modernisation on the family. The second part puts forth non-traditional readings of Cuando los hijos se van from a perspective that takes into account counter-hegemonic receptions. The film can be seen as containing indications of the possible benefits of modernisation and an underlying suggestion of progression to a more liberal, modern world on the basis of the religious significance of its characters. A study of these symbolic elements adds a new perspective to the film. ${ }^{8}$ In particular, it shows that although the Catholic family model is a central image of the film, the film also contains a religious allegory that could help Mexicans adapt to a new social order. Thus, this chapter realigns this important Mexican film, as part of a broader concern with the post-Revolution process of modernity that plays a major role in the Golden Age of Mexican Cinema.

\section{$\underline{\text { Religious Symbolism and Messages of Regression in Cuando los hijos se van }}$}

Cuando los hijos se van contains many elements of a religious melodrama, most forcefully suggested by the film's allegory and symbolism. Before closely examining these, a brief summary of the film is essential. It tells the story of the Rosales family, who live in an undisclosed Mexican state. They are portrayed as the archetypal Mexican family: an involved and caring mother and father with five children. Pepe Rosales is a strict and considerate father, holding the most power in the home, while his wife Guadalupe is a housewife who takes the role of a Catholic wife and mother very seriously. The three children who cause the most contention in the Rosales house are Amalia, José, and Raimundo, although all five children are 'guilty' of moving out of home. José and Amalia in particular give in to 'sinful' behaviour, such as robbery, flirtation, and deceitfulness, endangering the sacredness of the family. By contrast, Raimundo is blamed for actions he did not commit and is eventually forced out of the house by his father. Over the course of the film all five children depart from the family home, leaving for Mexico City. Raimundo is eventually killed by a villainous moneylender as he tries to rectify his family's financial situation. Focussing on how the parents react to each upset in their life, Cuando los hijos se van paints a picture of the Catholic family triumphing in the end, as the Rosales family is restored in spite of the efforts of an unscrupulous moneylender and

\footnotetext{
${ }^{8}$ Until 2014, these elements had not been given sufficient consideration by other writers' analyses. The most significant attention was from Tuñón who notes the religious significance of the parents' Christian names, but goes no further in examining the links between the characters and their symbolic roles (1998: 132). However, Isabel Arredondo's recently published book has rectified this, examining the mother-son religious symbolism as a Catholic defence of maternal love. Nevertheless, this chapter approaches the symbolism from a different perspective to hers, with the aim of reconfiguring it for its suggestive potential.
} 
the temptations of the world. The film communicates its messages through its strong appeal to the emotions. Sara García, the film's main actress, points out its emotionalism: 'it is an immortal motion picture, no matter what is said against it. The cinema might end, but Cuando los hijos se van will go on. [...] The public goes to see it, they feel it, they cry' (as quoted in Mora 1982: 57). This over-powering sentimental component is ironic considering that one of the film's implicit messages is that acting on feelings is inadvisable.

Part of the way that the film guides the viewer's emotional response is through the use of a narrator, an unseen figure who provides flowery comments and background details, mainly when there is a jump in time. The narrator, referred to as 'lo invisible' in the credits, serves to make viewers feel affection toward the Rosales and the way they live their lives. He calls the father 'nuestro amigo Don José', he praises the diligence of the mother, and he tells viewers how warm and inviting the home is. Because he is an omniscient, God-like narrator, audiences are expected to believe him. In contrast to his perspective on the Rosales's home, Mimi, the much younger wife of Don José's friend and perhaps the character least guarded in her emotions and in her conduct, describes the house as 'tan triste' and as a place in which she does not want to spend much of her time. The omniscient narrator even instructs the characters, at one point imparting the following counsel to Raimundo: 'No te afanes más, pobre Raimundo. Tu destino está sellado ya'. Such comments suggest that events are predestined and that struggling against the inevitable is futile, thus communicating the same regressive message featured in Nosotros los pobres.

Cuando los hijos se van is claustrophobic, set almost entirely within the Rosales's home. The narrowness of the setting reflect that the danger to the family and to traditional ideas lies in any contact with the outside world. Tuñón notes the habit of the traditional family to make the home into a prison in Mexican cinema: 'En pantalla, para protegerse, la familia tiende al aislamiento. Parece que el mundo exterior nunca puede ser seguro' (1998: 129). Most of the film's action takes place inside. Mora draws attention to the importance of the inside/outside dichotomy present in Cuando los hijos se van, writing the following:

The Rosales household seems to be suspended in time with its walls effectively keeping out the disturbing society outside. Disaster invariably comes to any of its members who seek to break their bonds with the sacrosanct family and it is only when they have rejected the world outside and all personal ambition that they find security, a security disconcertingly based on their individual failure and dependent on a stultifying submersion within the family. (1982: 56) 
Mexican family melodramas often have a number of scenes that take place in the dining room. Tuñón suggests that this is because 'en el comedor confluye lo privado con lo público, el trabajo de ella y el papel de proveedor de él. Representa el sistema familiar, la hechura materna del sustento en el espacio representado por el padre' (1994: 141). Some of the most important scenes in Cuando los hijos se van take place at the family table, where conflicts affecting who is on the inside of the family structure and who is on the outside arise.

The way to most quickly and surely escape from the enclosed world of the family and tradition is the train. Eduardo Crawley calls the railroad the 'ultimate icon of progress' (1984: 8). According to Lindsey Collins, one of the most important effects of the railroad was to create 'a view of the world in motion' (2010: 93). As in a number of films from this time, Cuando los hijos se van sees the railroad as encroaching on the traditional framework of Mexican society, facilitating the departure of the children and connecting them with the corrupting capital city. Monsiváis, referring to Mexico City after the Revolution, opines the following: 'The city was modernity. Not a place of modernity, but modernity itself. If you lived in Mexico City you were different, because the rest of the country was so oppressed by tradition and customs and prejudices that it was impossible to live in' (as cited in Stechler 2004). This is also highlighted in the fact that Latin American countries are highly centralist, with supposedly little of value occurring outside major cities ('civilisation'), particularly the capital. Berg writes that the new opportunities for relocating oneself had a great impact on society because of the tumult that they inflicted on the traditionally close-knit families (1992: 27). As Cuando los hijos se van reminds the viewer, modernisation and progress split up families. It is not inconsequential that Amalia departs for Mexico City as soon as she marries a modern man, a woman's only ticket to the city. Federico, one of the Rosales children, leaves for Mexico City on the same day as his sister, excited to be boarding the train and escaping from the confines of the house. However, for family matriarch Lupe the train is a cause of disturbance. As the train departs, its thunderous noise carries over to the next scene as Lupe waters her flowers indoors. As the image and the noise of the train go around and around in her head she drops the watering can in her hand and puts both hands over her ears, as if trying to block out the thought. Raimundo is the one Rosales child who is not happy to be outside of the house. As the only faithful child, who told his mother that he would never leave, it is painful for him to be outside of tradition and family. Pepe believes that Raimundo has not left because he does not take life seriously enough, but Raimundo knows the dangers of modernisation, having learnt about them from his parents, and does not have an interest 
in rebelling against his parents or disappointing them. In these ways Cuando los hijos se van suggests a mistrust of modernity and a regressive attitude.

The main threat of modernisation to the traditional family is that temporal concerns such as money and career may take precedence over family. Lupe is keenly aware of this danger, as she recognises it as the opposite of what she has devoted herself to. When Pepe tells her that they have to console themselves with the knowledge that the reason for the absence of one of their sons is that he is studying for a career, Lupe responds, ‘¿Para qué lo quiero con carrera lejos de mí?’ This family-centric worldview is particularly evident in the emphasis placed on Christmas time, as the Rosales are shown spending several Christmas Eves together. Christmas is venerated, mainly by Lupe, because it means family togetherness and harmony brought about by the religious and sentimental quality of the season. For Lupe these are 'días santos' which are the 'más felices' of the year. The first time that the narrator leads the viewer into the Rosales house, it is Christmas Eve and attention is drawn to the Christmas tree and the surrounding commemorative items. Then the focus of the camera falls on the star, which Amalia is placing on the tree. Lupe is helping her with the tree decorating and tells her that 'todos los años la has puesto tú, y todos los años la bendición de Dios ha sido en esta casa'. According to Lupe's superstitious beliefs, Amalia's yearly activity ensures happiness for the coming year. At the end of the film, once the household is restored, Lupe instructs Amalia to put the star on the tree, as she had done at the first Christmas shown. Lupe tells Amalia that by omitting the Christmas star she has forgotten 'lo más importante'. 'Lo más importante' is not the star itself but what it represents: the maintaining of tradition. By fixating on the star the implication is that tradition and religion have triumphed over secularism, all being restored to the ideal situation that existed at the start of the film and in this way providing the reactionary viewer with some degree of security.

The importance of Christmas time for maintaining family and faith may be noted most clearly in the final Christmas shown in the film. By this time, Lupe and Pepe have been left by all of their children and are facing Christmas alone, with the tragic death of Raimundo lingering in their minds. Lupe says the following to a sceptical Pepe:

Esta Nochebuena volvería a poner la mesa para todos. [...] Pero esta Nochebuena no esperaré en vano. Me lo dice la voz [...] de Raimundo entre las ramas. Y me lo dice la voz de mi corazón, Pepe. ¡Esta Nochebuena!

Lupe, who, as evidenced by the earlier example of her distress when the children leave, seems to be have some extrasensory perception, understands what Raimundo's sacrifice means for the family. Lupe knows that Raimundo's sacrifice signifies renewal and she feels now 'como si por las piedras de esta casa corriera sangre tibia, como en un cuerpo 
vivo'. She senses new life and is, of course, proven right in her prediction. All of the children come back on Christmas Eve because of Raimundo's death. This further establishes the 'magic' of Christmas: Raimundo calls the children back to the true faith, similar to how Christmas calls individuals back to tradition by placing ideas like redeeming miracles and family in the forefront of people's minds each year.

Cuando los hijos se van takes the danger of 'the love of money' seriously, with numerous moments showing the negative effects of greed, which Pepe calls 'el demonio de la codicia'. While José's selfish action of stealing money from his employer has the greatest impact on the family as a whole, Amalia's covetous attitude perhaps threatens the continuation of the traditional Catholic family unit the most, particularly considering that she is the only Rosales daughter. This demonstrates Monsiváis's assertion that films from this time 'exalted the repression of instincts in favour of moral servitude' (1995b: 119). In the first scene of the film, Amalia expresses her discontent with her family's financial situation, telling her surprised mother that she is not satisfied with her life. Complaining that she is never able to have luxurious clothing or break free from the monotony of daily life, she calls herself 'una esclava de la casa'. Lupe cannot understand Amalia's attitude, which emphasises material possessions and personal desires over family and duty. She reminds Amalia that she possesses more valuable things, namely 'el cariño de tus padres, salud, buena educación y una casa'. Later in the film, Amalia seeks to escape from her family and what she considers to be their 'poverty' by marrying an older man who is wealthy, a decision which is a figurative slap in the face to her parents and to tradition. Amalia says that 'por no pasar más pobreza, ¡sacrifico cualquier cosa!'. The Rosales parents think that she should marry their old friend Luis, because even though he is not rich he is a man of 'sacrificios y honradez' according to Pepe, most notably in his willingness to care for his widowed mother. Lupe is particularly upset that Amalia will not be able to have a religious ceremony, as her fiancé is a divorcé. Amalia takes ownership of her body and uses it to free herself from her father's authority.

In her quest for financial advancement, Amalia also rejects the importance of the Church, telling her mother that 'lo importante no es la bendición de un cura, sino las obligaciones legales'. Not only does this deny the power of the church, but it also exalts in its place the role of the state. Amalia's modern ideas are later proven to be wrong and she is punished for not following the traditional way, as she is left by her husband. Her mother's warning that 'el amor sacrificado al interés toma siempre amarga revancha' is proven to have merit, which Amalia admits in tears in the idealistic ending of the film. By trying to create her own destiny and following her desire for wealth, Amalia has 
brought unhappiness upon herself. Berg interprets the message of Amalia's cautionary example as being that 'it is better for non-elites to remain where they are; the rich have more problems than they do' (1992: 25). The father's strong reaction to Amalia's choice is also explained by Berg, who writes that 'Amalia's leaving the family to marry wealth is understood by her father to be prostitution, an effrontery to patriarchy and machismo and a blemish on Mexican womanhood' (1992: 24).

More threatening ideas about marriage and financial gain are also seen with Pepe's old friend Pancho and his new wife, who is a year younger than Pancho's daughter. Marriage is important because it creates families, but it is clear to the Rosales and their friend Don Casimiro that Pancho's marriage to Mimi is based on what they would consider to be less acceptable grounds. They suspect that he has married her as a 'trophy wife', while her interest in him seems mostly likely due to his wealth. The improper intentions of Mimi become more apparent to the naive Lupe when Mimi surprises her by freely admitting that she has no interest in having children. For Lupe, part of a woman's worth is found in being a mother, as evidenced by her bewildered statement to Mimi that 'parece increíble que una mujer no quiera ser madre'. Unsure how to respond without offending her guest, Lupe says that 'cada uno tiene sus ideas', the implication being that new ideas which contradict presuppositional Catholic beliefs, such as the blessing of pregnancy in marriage, are not wise. Guadalupe has been satisfied with her traditional and patriarchal ideas and believes that they are based on divine, immutable mandates. Rather than trying to force others to think the same way, as Pepe is more prone to do, Lupe appeals to the mother-child bond in her relationships, which allows her to subtly implant her assumptive worldview in others. Only Mimi and Don Patricio make deliberate efforts to resist her motherly charms, but this is not surprising considering that these characters are framed as immoral. In keeping with Lupe's singular role as a mother, she is unconcerned about money except as it relates to her children, which is seen as a noble attitude toward 'filthy lucre' in the film's philosophy of life. Material objects may tempt Lupe, such as the coat that her husband tries to give her, but the implication is that denying oneself and clinging to the concepts of family and morality will bring greater fulfilment in the long run.

It also should be noted that the film's villain, Patricio Gómez, is closely linked to money, as his occupation is a moneylender. ${ }^{9}$ According to Berg, this man is 'a lower-class character who rose in class at the expense of his humanity' whose 'ruthlessness and greed are clear evidence of the corrosive nature of monetary success' (1992: 25-26). Wealth is

\footnotetext{
${ }^{9}$ Perhaps not surprisingly, rebellious son José's occupation also involves money: he works at a bank.
} 
shown to corrupt and harden one's heart to the needs of others and to the spiritual dimension: as Raimundo sings to his mother about her likeness to the Virgin Mary, Gómez's simple lower-class workers are moved to tears, but the moneylender himself is not swayed by such sentiment. Don Patricio cares nothing for the family home or family itself, in this way setting himself up against the moral backbone of society. Sentimentality based on religious and familial devotion has no place in a modern, materialistic world according to the actions of Patricio Gómez and José and Amalia Rosales. Because of Gómez's and José's greed, lives are placed in danger. José fears for his safety, while Don Patricio and Raimundo lose their lives. According to Berg, the message that should be taken away from this film is that having just enough money is the ideal, because it makes one more authentically Mexican (1992: 25). While such a lesson may be in Cuando los hijos se van, the film is not as much of a celebration of poverty as Nosotros los pobres is. The overriding message is not that the strength of Mexico is found in living with little money, but that Mexico's strength exists in living connected with each other, particularly with one's family. The danger in wealth is that money brings with it new technology and new technology tends to lead to less emphasis on relationships. This is perhaps the greatest fear of Cuando los hijos se van.

Lupe Rosales is at the heart of the film. This character has a strong link to the past and tradition, partly because of her role a mother. For example, the relationship between Lupe and her son Raimundo suggests a similarity to the Virgin Mary, which is in keeping with the marianismo ideology. Marianismo is defined by Evelyn P. Stevens as the 'cult of feminine spiritual superiority, which teaches that women are semidivine, morally superior to and spiritually stronger than men' (1973: 91). This belief is supported by Catholicism, by pointing to teachings from the Bible about the role of women that suggest a complete submission to male authority. According to these ideas, women should emulate the Virgin Mary, who submitted herself to God, a male figure. The Mexican equivalent of Mary, for Hispanic women to identify with, is the Virgin of Guadalupe, as unsubtly suggested by the given name of Lupe. ${ }^{10}$ By encouraging women to think of themselves as superior morally and spiritually to men, marianismo compensates for the limitations placed upon women. Lupe, for example, is rarely shown outside of the house. At one point she tries to leave the house to see her son, but Pepe restrains her. Lupe never wavers in the belief that her beloved son is innocent of the accusations of her husband, and even goes against Pepe's wishes by bringing him food and helping him surreptitiously

\footnotetext{
${ }^{10}$ As further evidence of the importance of religion and allegory in Cuando los hijos se van, her husband's first name is José, the same name as Mary's betrothed.
} 
leave the house to see his girlfriend. As the perfect Catholic mother, her devotion is first and foremost to her children, not to her husband, and when she is challenged by her daughter as to why she considers herself to be happy, Lupe says that it is because 'todos mis hijos son buenos y gozan de salud'. Raimundo realizes that he has a special relationship with his mother, at one point imploring her to maintain her trust in him. However, the most unmistakable comparison of Guadalupe Rosales to the Blessed Mother is found in a song that Raimundo sings for his mother. To express his devotion to her he sings the song 'Madre mía', in which he proclaims: 'La Virgen María, eres tú madre mía. [...] Como aquella María, madre del Redentor'. Raimundo, the good, Christ-like son recognises the moral rectitude of his mother at all times. In contrast, José, the bad and duplicitous son, does not bless her. As part of his return to the fold, José needs to recognise how important his mother is, which comes after she explains the spiritual significance of Raimundo's death. As he realises that the forgiveness Lupe tells him about is possible, José exclaims, ‘¡Madre! ¡Madre mía!’ The film itself is a kind of ode to motherhood, with the only music in the film featuring the strains of the composition 'Madre mía' by Joaquín Pardavé, which in itself further reinforces the presence of Guadalupe. Her almost exact likeness in spirit to the Virgin supports traditional patriarchal views of women as sacrificial and forgiving, rather than providing ways for Mexicans to move on from such ideas. This is a message that seems reiterated by the film's depictions of the negative effects of modernization on the family. Despite the traditional world of the Rosales, in post-Revolution Mexico no family or individual was immune to the changes occurring in the country. The Revolution was supposed to have brought progress and enlightenment to Mexico, but there was resistance and sometimes more of an illusion of progress than it being an actuality.

\section{A Modernising Drive in Cuando los hijos se van}

The film's allegiance to traditional Catholic values, the fetishisation of the mother, and its emphasis on preserving the family unit, as well as its distrust of modernisation, is partly a reflection of the influences of Catholicism on filmmaking during the Golden Age of Mexican Cinema. Despite this influence, it still can be argued that the film actually provides help for audiences to move on to a new social order. Although modernisation often implied the breakup of the traditional, united family that the film fervently defends, the film reluctantly accepts that Mexicans have a need to adapt to the modernising process. The following analysis will demonstrate that, although the Catholic family model is a central image to the film, the film also contains a dynamic reconfiguration of religious 
allegory that could indeed help with the adaptation of Mexicans to a new order.

Pepe Rosales, the father figure in Cuando los hijos se van, rules over his house, creating an air of tension. To some extent, he keeps his family locked up, particularly when he feels that his word may be challenged by them leaving the house. He sends Raimundo to his room. Later, he locks Lupe in their bedroom, so she cannot interfere with his discipline. His presence is, at times, threatening, and his anger teeters on the edge of violence. Referring to Pepe's hard-heartedness, his friend calls him a 'saco de bilis'. He keeps a gun in his desk. At one point this anger manifests itself in hitting one of his sons. $\mathrm{He}$ is not affectionate with his children, rarely touching them, and when he does it is unlikely to be tenderly like the mother does. While Lupe embraces Raimundo when he returns, Pepe will not even look at him. Pepe does not appreciate that his son is taking singing lessons, as this breaks traditional familial and societal expectations. He acts like an all-knowing father presiding over foolish children. When one of his sons asks him why he is being sent to his room, Pepe barks, '¡Obedece!' However, this characterisation is offset by more positive qualities: he is not intended to be a villainous or unlikable character. His conduct is particularly laudable in relation to his wife, although Pepe still does exhibit signs of trying to control Guadalupe. In one of the film's most memorable and emblematic scenes, Pepe gives his wife a luxurious coat as a sign of his love for her, clearly fighting back the tears as he tells her how grateful he is for her. In a way, he is an ideal Catholic father, because he loves his wife and treats her like a saint. Rather than working against this image of a model father, his violent tendencies and domineering nature show his care for his family.

In an allegorical reading of Cuando los hijos se van, the Rosales parents may be seen as representing the two sides of the Christian God reflected in the Old Testament and the New Testament. In Christian theology, the Old Testament depiction of God, or Yahweh, and the New Testament depiction (particularly in relation to Jesus Christ) are difficult to reconcile because of their perceived differences: in the Old Testament, God appears harsh, violent, distant, exclusive, and xenophobic; while in the New Testament His incarnation as Jesus Christ makes Him seem more compassionate and inclusive. The somewhat harsh character of Pepe Rosales, particularly the way he rules over his domain and his children, is reminiscent of the paternalistic figure of God in the Old Testament. For an historical Mexican equivalent, he may be associated with Porfirio Díaz and his way of ruling. The father resembles the Old Testament God but is presented in somewhat of an unfavourable light - not only because he is violent, cold and dictatorial, but also because these features bring him close to Porfirio Díaz. In turn, this association can be 
seen to fit into the Mexican Revolution's discourse of adaptation to a more secular society.

The mother plays both an opposing and complementary role in the family to Pepe Rosales. She embodies a softer but still conservative figure who serves as a kind of transition from the Porfiriato to a less traditional or dictatorial approach to governance. While Pepe most closely represents the first Person of the Trinity, the Father, Lupe's ways of dealing with her children are more reminiscent of the second Person, God's Son Jesus Christ. In spirit she exhibits key character traits often associated with Christ, such as being more caring, open-minded, tolerant, and sacrificial than the Father/father. ${ }^{11}$ When one of her sons is assumed to have acted in a highly inappropriate manner, Pepe Rosales does not want to speak to him and orders him out of the house, proclaiming that 'su falta es demasiado grave'. In contrast to her husband's attitude, Lupe declares that 'nada me importa su falta', insisting on giving him her blessing. She demonstrates a propensity toward grace and forgiveness, instead of being quick to judge and draw conclusions. Near the end of the film Pepe admits to her that 'siempre has visto tú antes y más profundamente que yo', suggesting that her ability to manage conflict with understanding and patience is the way forward.

Raimundo is a character who is pure in heart, almost child-like in his innocence. As Arredondo notes, he is a character who clearly represents Christ in the film, bringing the family back together (2014: 143). Like Christ, he acts as a scapegoat because he takes the punishment that his wayward siblings deserve. The first such incident occurs on Christmas Eve, when Raimundo is blamed for stealing money from his father's friend. The second and more serious episode takes place when the young wife of Pepe's friend is found to have an unknown man in her room, with the evidence pointing to Raimundo yet again. Both accusations against Raimundo's character are completely incorrect, but after the second incident he is expelled from the home by his father. Later he returns to his parent's house, intending to save the family home from being taken as payment for debts by confronting the moneylender Patricio Gómez. After Don Patricio has shot Raimundo, by sheer will power alone Raimundo makes his way towards Don Patricio and hits him over the head with a paper weight, killing the man intent on destroying his family. He sets his family free from evil's clutches, but pays for that freedom with his life. As he is dying, he tells his father, 'Dile a mamá que ya está libre la casa otra vez. Libre con mi sangre y con mi corazón'. In doing this, Raimundo purifies his family from the danger of selfishness. Lupe makes this Christian symbolism impossible to miss when she tells José

\footnotetext{
${ }^{11}$ She is not, however, an allegorical representation of Christ. Instead she exhibits a more general New Testament spirit.
} 
that Raimundo has paid for his sins and thus allowed for his restoration to the family, as Christ has.

The allegorical elements may also be observed in Raimundo's relationship with his father, as a reflection of the Father-Son relationship between God and Jesus Christ. When accused by his father, Raimundo tells him, 'Cuanto más grave sea la falta que por alguno de ellos tenga que pagar, soportaré el castigo con menos resentimiento, porque así te sirvo más, padre'. He recognises that he is taking the blame for others' wrongdoings and also understands that by doing so he is part of his father's plan. Lupe, after Raimundo has died, says to Pepe that she feels that 'mi hijo vive en toda la casa, que nos acompaña y que nos anuncia el retorno de todos los demás'.

Following this allegorical reading of Cuando los hijos se van, if there is a saviour then there also must be someone in need of saving - in religious terms, a sinner. José, one of the Rosales sons, is the clearest representative of the sinner. Unlike his sister Amalia, who goes beyond the bounds of acceptability without shame, José's sins are kept secret and are more deliberate, affecting people other than himself. Pepe Rosales favours his oldest son, believing that José is blameless in all matters, which is partly why his wrongdoings go undetected. In the true melodrama tradition, bad masquerades as good before all is brought to light, with characters like Pepe stubbornly refusing to believe that what he sees as good may not be so. At the end of the film José repents of his wrong-doings before his parents, the visible representatives of the Trinity, and his siblings, his fellow transgressors of the parents' law. José's repentance at the film's end is full of selfdepreciation, acknowledging that he has behaved in an unforgiveable way and is undeserving of grace. Being convicted by the Law, grace, as physically represented in the mother, intervenes to show him the way to freedom - accepting Raimundo's death as a blood sacrifice. Lupe leads José back to the table, with the father's permission, and he is incorporated back into the family.

The Apostle Paul, one of the key figures in the early Christian Church, addresses in his writings the transition from the Law to grace that he maintains must occur for the formation of Christianity, a transition that involves somewhat revolutionary ideas in the views of some of his contemporaries. The 'freedom in Christ' he emphasises in Galatians 3:23-26 instead of slavish obedience to the Law sounds like a dangerous liberty - and a possible means of escape from traditionalism. William Webb has argued that, as opposed to being static and regressive, Christianity encourages a 'redemptive spirit' to culture, with the view that God is redeeming culture and making it more just. Webb writes that such a hermeneutics 'encourages movement beyond the original application of the text in 
the ancient world' (2001: 30). This perspective maintains that there is a modernising, egalitarian drive to Christianity, as God's dissemination of grace becomes more complete. With these ideas in mind, Lupe can be seen a figure who offers a new way forward. She acts as a bridge between Old Testament 'justice' and New Testament permissiveness, perhaps a reflection of the fact that the Mexican filmmaking process was active in trying to help audiences find ways to adapt to the new society. ${ }^{12}$

\section{Conclusion}

As Gledhill notes and Cuando los hijos se van illustrates, the struggles and contradictions of modernity that define national identity are found, on a representational level, in the family unit (1987: 31). The film offers an underlying religious allegory that invites a comparison of the transition from Law to grace to the transition from the Porifiriato to the post-Sacred Mexican society of the mid-twentieth century. While it certainly contains elements that exalt traditionalism and retrogression, Cuando los hijos se van is able to be aligned with other Mexican melodramas of the time which also celebrate tradition while acknowledging the need to adapt to post-Revolutionary Mexico.

\footnotetext{
${ }^{12}$ While this analysis is partly based on viewing the film's ending as a step toward acceptance of change, it should be noted that Berg believes that the conclusion, rather than offering any potential for progress, trivialises the tragedy of Raimundo's death because it is an attempt 'to sweep such untidy facts under the hegemonic rug' (1992: 22). Berg observes that in the film blind faith comes with disastrous consequences, most notably the death of an innocent young man, and that it merely reaffirms the concept of undiscerning beliefs even while secrets are brought out in the open.
} 


\section{CHAPTER 4}

\section{PEDRO INFANTE AND THE CINEMATIC REPRESENTATION OF MASCULINITIES}

As maintained throughout the first three chapters, conflicting tensions were present in many Mexican films during the decades following the Mexican Revolution. Some films encouraged traditional views on issues like religion, but also suggested that new ways and beliefs may have a role to play in the modern society in formation during the Golden Age of Cinema. The treatment of male identity in these films also displays contradictory tensions that stem in part from a process of adaptation to modernity.

In order to explore these themes further, this chapter focuses on the figure of popular Mexican actor Pedro Infante and the images of masculinity that his films projected. It argues that both Infante's biographical details and the features of his fictional characters reflect the concerns of the modernising process in Mexican society. In order to demonstrate the modernisation which his characters undergo, a comedy, a melodramatic trilogy, and two interconnected musical-comedies from Infante's career will be analysed. These films are ordered chronologically, to show that his characters move closer toward a modern version of masculinity as time progresses, thus serving to bridge Mexico's ruralurban divide. Firstly, the early anti-feminist comedy Arriba las mujeres (1943) will be discussed in terms of the modern city's threat to machismo and opportunity to empower women. Then the Nosotros los pobres trilogy, Infante's most famous melodramas from the late 1940s, will be examined with a focus on how they suggest a masculinity in transition from a rural mind-set to a more urban one. Finally, evaluation of two of his urban buddy comedies from the early 1950s will point out the connections between male bonding and the construction of the post-Revolutionary Mexican nation. This analysis of Infante and his films suggests that the movement in Infante's characters, which mirrors the progression of Infante's life and persona, shows how men could successfully transition their traditional lower-class masculinity to fit into post-Revolutionary society.

\section{Masculinity as Performance in Mexico}

Before focussing specifically on Infante and his connections to modern Mexican masculinity, a brief summary of the place of men in Mexican society in mid-twentieth century will serve as a useful framework. Similarly to how women were expected to perform a certain version of femininity in Mexico at the time, men also had to conform to the dominant conception of masculinity. Clearly, both identities are enacted through 
performance, but whereas expectations about women's behaviour are often articulated or explicitly understood, male performance has been historically dependent on unspoken social expectations (Horrocks 1995: 18).

The concept of machismo, especially in its Latin American and Mexican incarnations, is important for understanding expectations surrounding masculine identity in Mexican society. A. Rolando Andrade links this social phenomenon to the history of conquest in Latin America. According to him, it can be seen as 'the driving force of a conqueror or of a man with fondness for combat' (1992: 34). Michael Hardin confirms this notion, asserting the following:

Machismo is a legacy of the conquest, of the Spanish conquistadores and the two-spirit. It was the product of the rape of indigenous women, the response to indigenous imperial ritual, and the sublimation of indigenous male sexualities and genders. (2002: 20)

While some thinkers, such as Berg, have suggested that there is also a positive kind of machismo which is 'humane, responsible, and protective' (1992: 23), the phenomenon tends to be destructive and encourage inequality and is often associated with violence. According to Andrade, men who perceive themselves as true machos 'believe that through aggressive activity they can display their courage, valour, strength, and virility' (1992: 34). Octavio Paz writes specifically in relation to the Mexican macho that 'the essential attribute of the macho-power-almost always reveals itself as a capacity for wounding, humiliating, annihilating' (1985: 82).

In addition, machismo entails an inability to open up one's feelings to other males for fear of showing vulnerabilities. Specifically in relation to what she calls 'Hispanic male sexuality', Nikki Craske argues that it is based on 'fear of being perceived as feminine' and, thus, she concludes, being vulnerable and open is prohibited (Craske 2003: 207). This is because traditionally in Western culture feelings are considered more appropriate for women, while men supposedly have been given a greater inclination to reason and 'common sense'. For instance, R. A. Sydie brings up the influence of this notion upon the dominant male-centred discourses of intellectuals of the European Renaissance in the following excerpt:

For many Renaissance thinkers and medical men, the uterus was the source of women's greater proneness to hysteria; not only did it weaken their rationality, but also increased the incidence and violence of the passions of hate, vengeance, fear and anger. All these emotions were thought to hold greater sway over females, although compassion, pity and love were also more common to women and could soften the effects of the former emotions. (1994: 3)

Machista images projected by the films of the Golden Age of Mexican Cinema 
need to be understood in terms of the construction of masculinity disseminated during the Mexican post-Revolutionary period. The Mexican Revolution encouraged an image of the fearless male dedicated to his country. According to Monsiváis, 'si la Revolución crea los espacios de desarrollo de una sensibilidad distinta, también los revolucionarios se jactan de un machismo rampante' (2000: 32). De la Mora writes that in PostRevolutionary Mexico 'cinema was instrumental in the invention of the Mexican macho: virile, brave, proud, sexually potent, and physically aggressive'. Such an ideal man was in support of the Mexican state's sexist discourse of the time, designed to provide stability after the Revolution and maintain power for the ruling Partido Revolucionario Institucional (PRI). Under this system, the state offered men a privileged social position in relation to women in exchange for their support of what de la Mora calls the 'hypermasculinised nation-state' $(2006: 7,5) .{ }^{13}$ Berg maintains that the male image was closely connected to the image of the state. He explains this arrangement in the following manner:

Through it the individual acts out an implicit, socially understood role-el macho - which is empowered and supported by the state. The state in turn is made powerful by the male's identification with and allegiance to it. Both the nation and the individual male forge their identity in the macho mould. (1992: 107)

As Berg further notes, 'to speak of the male image in Mexico is to speak of the nation's self-image and ultimately to speak of the state itself' (1992: 107). In this way, a crippled masculine self-image means a weakening of Mexico as well. Therefore, men must at least appear to be in control, so that the state appears to be in control. Mexican society itself, unstable since 1910, risks becoming more unsteady if the structure that Berg describes comes undone.

Considering this situation, it is not surprising that most of the male characters appearing on screen during the Golden Age were virile, heterosexual, and strongly Mexican. These were played by actors such as Jorge Negrete (1911-1953), the singing charro; Pedro Armendáriz (1912-1963), 'stalwart leader of men'; and, of course, Pedro Infante (Dever 2003: 55). Even though these stars tended to reinforce traditional conceptions of the masculine as strong, hard, and impenetrable, Pedro Infante's male characters in particular display ambivalences that suggest a more fluid conception of Mexican male identity. His association with the rural and the lower classes are also important considerations, especially when viewed in light of Robert McKee Irwin's and

\footnotetext{
${ }^{13}$ A relevant piece of information in regards to this point is that Mexican women could not vote in national elections until 1953 (Berg 1992: 55).
} 
Doremus's claims that the nationalist goal partly depended on the exaltation of the lower classes (including lower-class masculinity) as more authentically Mexican and a model for others to follow (Irwin 2003: xxxii, 115; Doremus 2000: 42).

\section{Pedro Infante's Stardom and the Importance of His Body}

According to de la Mora, Pedro Infante is one of the most popularly revered actors in the long and rich history of Mexican cinema, a kind of 'secular saint' (2006: xii). His status as a quasi-religious figure ties into the view of cinema as a new form of religion and hints at his bridging of the traditional ('saint') and the modern ('secular'). A brief biography and analysis of his public perception in this section will provide the necessary background to an examination of the progression of the masculine identities that he projected.

Pedro Infante was born in 1917 in Mazatlán, Sinaloa, to a lower-class family. He worked as a carpenter throughout his adolescence (Monsiváis 2008: 51). Jorge Carrasco Vázquez writes that partly due to these humble beginnings, for some 'a Pedro Infante se le considera como un miembro más de cualquier familia mexicana' (2005: 9). Infante himself draws attention to the fact that he came from a lower-class background and received less formal education in the following quote:

Siendo aún niño tuve que enfrentarme a la vida. [...] Si de algo puedo ufanarme, aunque no lo hago, es de haber luchado siempre, de haber vencido la miseria [....] Pues, aunque esté fuera de tono, yo me precio de ser un buen hijo y de querer a los de mi sangre, como creo que debe ser. (As quoted in Monsiváis 2008: 51)

Infante seems to refer to his hard early years as evidence of his being a normal Mexican to whom his fellow citizens could relate. The rags-to-riches character of his biography is indeed part of the enduring nature of his appeal, as is the ordinariness and warmth of his manner and appearance. His description of himself as 'un buen hijo' emphasises the importance of family to him, reflecting a recurring theme in his films.

Infante died at the peak of his career, which perhaps helped cement his status as a young, handsome icon. In April of 1957, at the age of 39, he died in a plane crash, leading to a national outpouring of mourning which Rubenstein details and analyses. In her article she notes that the fan publication Cine Novelas observed that Infante's death 'moved all classes of society. But it was, especially, the masses who wept for him' (2001: 208). In regards to the impact of his death, de la Mora sees it as a symbolic loss of hope for lowerclass Mexicans (2006: xii). These critical contributions underscore the importance of the lower-class elements of his image and the popular significance of his death.

At the time when Infante was popular, the Mexican film industry had a star system 
similar to Hollywood's, which had been inherited from U.S. theatre and which, in turn, had come from the British stage (McDonald 2000: 16-17). In these original contexts, as early cinema moved from being less of a novelty and spectacle to a more narrative form with an emphasis on stories and characters, film industries saw financial gain in using readily identifiable performers. These performers, or 'stars', were a way to encourage audience loyalty, with particular stars becoming associated with particular kinds of films. Richard DeCordova writes about the following about the 'production' of stars:

The star system does not produce stars the way that a factory produces goods. The system is rationalized, but it is not geared toward producing a standardized product in the usual sense of the word. It produces a product that is in fact highly individuated - the individual star. Images of machinery and the production line when applied to the star system may in some ways be appropriate, but they risk oversimplifying the processes that work to produce the star as individual entity. (2001: 9)

Therefore, the creation of stars is a complex process leading to highly unique stars who are, nevertheless, still readable as 'types'. DeCordova writes that 'the individuality of the star is never irreducibly outside of the star system since the system is geared toward producing just such individuality' (2001: 9-10). The system works to make it seem as if a star's public identity is 'authentic' and not carefully constructed. The individuality and 'authenticity' that it seeks to attain for its stars is not produced solely by the on-screen images of famous actors. Dyer writes the following about the creation of a star's identity:

A film star's image is not just his or her films, but the promotion of those films and of the star through pin-ups, public appearances, studio hand-outs and so on, as well as interviews, biographies and coverage in the press of the star's doings and 'private' life. Further, a star's image is also what people say or write about him or her, as critics or commentators, the way the image is used in other contexts such as advertisements, novels, pop songs, and finally the way the star can become part of the coinage of everyday speech. (2004: 2-3)

Dyer's last point suggests that a star's identity partly depends on fans' interaction with his or her images. As DeCordova notes, 'the star's identity is intertextual, and the star system is made up in part of those ongoing practices that produce the intertextual field within which that identity may be seized by curious fans' (2001: 12). Paul McDonald writes that 'the meaning of a star's image is therefore not contained in the sources that represent the star but is produced in the moment of interaction between moviegoers and star texts' (2000: 7). In a similar way to how audiences can reinterpret films, they can also emphasise the aspects of a star that are of greatest importance to them.

The importance of Pedro Infante as a star is due in part to the effect of stars on society at large and their influence on the viewing public. As Raymond Durgnat observes, 
'the social history of a nation can be written in terms of its film stars' (1967: 138). Infante's star power was in his personality's appeal to ordinary Mexicans, which gave his fellow Mexicans points of identification with him. Rubenstein points out that 'in the eyes of his audience, both before and after his death, Infante's appeal lay in the excellence, but also the ordinariness, of his character' (2001: 212-13). The actor himself acknowledged that it was the public that made him into the star that he was, thus downplaying the role of the star system and acknowledging the agency of his fans. Jesús Amezcua Castillo quotes him as saying, 'Todo lo que soy se lo debo al público; ese público tan generoso y querido que me ha dado más de lo que yo esperaba' (2007: 155).

Infante gave the impression that he was enjoying his work as an actor. This carries over to his image as an athletic man who saw physical exertion as a hobby not an unpleasant task. According to Dyer, for male stars 'sporting activity is a major-perhaps the major-element in their image; they are defined above all as people for whom having uncomplicated fun is paramount, and this is implicitly carried over into their reported attitude to their work' (2004: 6). The twentieth century brought with it a number of new 'sports' based on technological advancements that quickly became associated with men. These included riding motorbikes and piloting planes, both of which Pedro Infante expressed interest in during his lifetime. His aptitude for these potentially dangerous activities made him seem bold and daring. Such leisure pursuits showed him to be a modern man, who brought his masculine strength to Mexico City and adapted it to the new surroundings.

Kenneth MacKinnon writes that 'male stars' erotic appeal is no less credible than that of female stars, although it may be far more masked and alibied' (1997: 72). Cohan maintains that 'the apparatus of stardom turns him into a spectacle, valuing him for his whole body as well as his good looks even more than for his impersonation of agency' (1997: xvi). It is unlikely that any other actor's bare chest from Mexico's Golden Age was shown as much as Infante's, providing suggestive sensual images for Mexican female audiences. De la Mora provides some helpful information on this topic:

Infante enthusiastically participated in displaying his body through his interest in physical fitness and the culture surrounding it. Press coverage described Infante as an emblem of a disciplined, healthy, athletic, authentic, and natural man of working-class roots. (2006: 75)

His physical perfection was important to his fans, who were upset when one biography revealed that he was diabetic (Rubenstein 2001: 230). Infante's status as one of the great Mexican pin-ups points to the importance of his body. This is especially significant considering that in this time period it was uncommon for male stars to be pin- 
ups, either in Mexico or in Hollywood. In Dyer's analysis of the male pin-up, he writes that 'whether the emphasis is on work or sport or any activity, the body quality that is promoted is muscularity. [...] Muscularity is the sign of power-natural, achieved, phallic' (1982: 68). He also contends that a desirable male body stands out from others, marking itself as superior. Despite the inherent vulnerability of a body on display, Dyer notes that an aesthetically-pleasing male body is 'hard and contoured, often resembling armour' (2002: 265, 269). As Brian Pronger maintains, 'the masculine development of physical strength certainly fortifies the power relations between men and women' (1992: 44). In Mexico, the need for the display of such a body and, by implication, a certain model of masculinity, was partly due to the time period. Irwin affirms that following the Mexican Revolution 'virility came to be the metonym of Mexicanness' (2003: 152). Pedro Infante fulfilled the role of such a virile man. Because of the hardness of his body, he appeared at his least vulnerable when his muscular physique was on display, a stern facial expression often challenging any attempt to see him as unconditionally open or as a penetrable or mouldable being. Rubenstein points out that Infante had his own private gymnasium to work on maintaining his physique, the insinuation being that money can produce a muscular body and, in turn, attract women (2001: 209).

\section{The Traditional Collides with the Modern in Arriba las mujeres}

Arriba las mujeres is one of Infante's earliest films and, while he does not play the protagonist of the film, his character is perhaps the most memorable. At first glance, Arriba las mujeres is thoroughly anti-feminist. It has been described by Monsiváis as a machista parody of feminism (1994b: 55). While the ensuing analysis accepts the presence of strong anti-feminist elements in Arriba las mujeres, it also suggests the possibility of a more open reading, in line with the ambivalence of the figure of Infante outlined earlier. By contrasting the film's portrayal of modernity with its depiction of traditional influences, this section argues that Infante's character acts as a means of reconciling modern feminism with the traditional construction of the romantic idealised male from the rural areas.

Arriba las mujeres, released in 1943, is a comedy film partly about a young man named Chuy, played by Infante, and his girlfriend Chole. At the beginning of the film Chole leaves their small town in Chihuahua to go to Mexico City to undergo training in how to be a woman by her godmother's daughters, as her father wants her to be ready to marry Chuy. Her father says the following to a friend:

Quiero entregarla en buen estado. [...] La voy a llevar a casa de mi compadre Próspero y mi comadrita Felicidad pa'que sus hijas, que son muy mujercitas, 
le enseñen a hacer comidas elegantes, pasteles de ésos de fondas de pomada, que le enseñen a bordar.

However, upon arriving at her godmother's house in the city, Chole discovers that she and her daughters are feminists, 'mujeres modernas', involved in a women's liberation movement called the Camisas Pintas. They have taken over control of the house from Don Próspero, the husband of Felicidad, who feels emasculated by this. The film subtly mocks the three feminist characters: the mother requires the daughters to applaud when she gives speeches trying to motivate the women of the Camisas Pintas to be independent, and her doctor and artist daughters never seem to have any clients or make any money from their professions. Because the women all operate from their house (the doctor and artist daughters have their office and studio there, for instance) and the house belongs to the patriarch, they do not have as much power as they believe.

Infante's character Chuy is worried that Chole's affection for him is changing as a result of being in the city and therefore comes to visit her in Mexico City. His reaction to discovering the unconventional education that his fiancée is receiving is one of shock. The following exchange takes place after he learns that she has become a 'mujer moderna' and a member of the Camisas Pintas:

Chole: Tenemos que defendernos.

Chuy: ¿De quién?

Chole: De los hombres. Que al casarse creen que compran una criada o una esclava. Eso te has creído tú, ¿verdad?

Chuy: No, yo nunca he pensado eso.

Chole: Así dicen todos.

Chuy clearly feels threatened and confused, and does not show any attempt to understand her new way of approaching womanhood. Chole decides that, since he will not support her in her feminist ideas, she must end their relationship. This decision, and the defiance displayed by Felicidad and her daughters, cannot withstand the male characters' attempts to return the women to their 'proper' condition. The men hold clandestine meetings to plot a return of their women to them and spend time in a bar where they flirt with beautiful women in the hopes of making their girlfriends or wives jealous. At the end, they take much delight in being able to return them to their suitable feminine roles.

As suggested by the above plot synopsis, the men of Arriba las mujeres use cunning means to overcome the women's rebelliousness. One way in which they do this is to appeal to the women's emotions, as they assume that women are more emotional creatures and therefore more easily manipulated, an assumption that the film overall also reinforces. This is perhaps most clearly exemplified by the way Infante's character deals with Chole's insolence. Chuy displays an implicit sexism through his unwillingness to 
understand her new views, but he is simple and eager. His romantic nature speaks of love and affection. At one point, he says the following: 'Por algo no encontraba sosiego con nada y todo se veía muy triste sin ti. [...] Adiós, Chole. Siento un nudo aquí en la garganta y no quiero que me veas llorar'. He also tells her that the natural world, the flowers and animals back in Chihuahua, has responded negatively to her newfound feminism which has made him so sad:

Los rosales de mi casa se secaron cuando antes floreaban rebonitos, [...] los pájaros [...] ahora cantan de un modo que parte el alma. [...] Mi perro por nada del mundo quería comer [y] las vacas se compadecían de mí.

Chuy's metaphors suggest that she is going against nature with her feminism. Although Chole does not give into the temptation to return to Chuy at that point, his appeal to her emotions eventually leads her back to him (and, by extension, back to the rural area). According to one of the male characters, the flaw of women like those involved in the Camisas Pintas is that for them 'el corazón no significa nada' when for 'normal' women their emotions should guide their actions and words. Chole and the other women of the household come to the realisation that they are being unreasonable and denying their emotions, and eventually they return to thinking more with their heart, as a woman allegedly should. The men have to be more expressive with their feelings to achieve this (one of the men even appears to shed a tear), but by doing so they can maintain the malecentric status quo.

One of the key concerns of the film is whether men or women have control of the situation, often represented through who best handles language. Arriba las mujeres implies that the rural characters, untouched by the modern ideas of the city, understand gender relations correctly, as suggested by Chuy and his future father-in-law coming to the city and being the catalyst for 'rectifying' the situation in which the women have control. Victor J. Seidler writes that as men "we learn to "master" language so that we can control the world around us' and that 'we use language as an instrument that will help show us as independent, strong, self-sufficient and masculine' (1989: 145). The issue in Arriba las mujeres is that the women have learned how to effectively use language in the way that Seidler notes men are expected to, which means the women can appear to be strong and autonomous. The female characters, particularly the leader of the Camisas Pintas, are in a dominant position at the beginning of the film. The most obvious example of this is the patriarch of the city household having no say in his home, with his wife ordering him around. At one point he is even seen doing the laundry. He complains that 'ni se me concede otro derecho que el de callarme', a statement which sounds more like a description of women's typical position in society at this time. In this situation, Infante's 
character Chuy also decidedly lacks control. However, through assertion and indirection he and the other men are able to regain control by the end of the film. Chole's rejection of Chuy's authority over her includes taking control of language by calling him a 'palurdo reaccionario', a term he does not understand. Later, when they reconcile and the normal gender relations of the time have been reinstated, it is Chuy who is able to use a word that Chole does not know, thus signifying a switch back to the men's control of language. The word is 'totalitaria'. He uses it in reference to Chole's incendiary godmother, whose words, ironically, have been rendered powerless by this point in the film. Now her totalitarian attitude has been reclaimed by the men, who have slightly softened their approach to make sure they remain in charge. Chuy's ability to control language only makes him more attractive to Chole, who compliments and hugs him in response.

This power shift is also reflected in the way in which the film's male characters reappropriate the cry 'iArriba las mujeres!'. This phrase is initially a call to encourage women to rebel against male domination, as heard in the song 'Arriba las mujeres'. A large crowd of women in the area outside Felicidad's house proclaim their desire to liberate themselves from the confines of the home and the dictates of men. They sing, 'Ajos y cebollas / guisos y carbón / ya no más escobas / todo se acabó'. However, in the men's mouths the phrase 'Arriba las mujeres' becomes a praise of beautiful and naturally emotional women. In this way, the men reverse the feminist intent behind the original song, which celebrated women's potential agency, and instead exalt women for the greatest quality they possess from a masculinist perspective: their value as aesthetically pleasing objects.

As implied by some of the examples cited from the film, urban masculinity seems to have a tendency to be weak. The remedy for this inherent weakness is the lower-class rural men. It takes the help of the men from the rural areas, including Infante's character, to deal with the distorted social order present in the city. It is important to remember that at the time this film was made, one of the Mexican Revolution's greatest problems was the division between the rural and the urban. The nation was dealing with the problem of culturally and socially distinct rural and urban sectors as well as the migration of rural workers into the city. The difference between the city and the country comes across clearly throughout Arriba las mujeres. As a character in the film notes, 'en la capital las cosas van cambiando'. The city represents modernity itself and away from the city ideas and practices are more traditional.

On the surface, it is clear that Arriba las mujeres tries to defend the rural traditional world against modernity. Chuy and Chole are from Chihuahua and are not highly 
educated. They live simply, like many rural Mexicans at the time. For them it is only natural for a young couple in love to marry, with the man working and the woman in charge of the housework. They are happy at the beginning of the film, before the train takes Chole off to Mexico City. Once Chole is in Mexico City their relationship begins to be undermined by the modern thinking that she is exposed to there, in particular feminist ideologies. While Chole's godparents have a large house and enjoy many luxuries, representing the allure of the city, they have abandoned some fundamental beliefs about family and life in general that it is insinuated they used to have before they were affected by the city's modernity.

Another implication is that cities tend to create weak, soft men, as seen in the figure of Felicidad's husband, who has been emasculated by his wife and her feminist behaviour. 'Proper' masculine roles, those represented by Chuy and Chole's father, clash with gender identities emerging in urban contexts. In the worldview of the film, Chole's godparents and their daughters have been corrupted by the city. The family are, of course, eventually put right by those from Chihuahua, who expose their charade of liberalism as a passing frivolity.

However, in some respects the film's narrative adopts an almost conciliatory tone toward modernity and the city at times. For example, in the film the city offers the possibility of breaking from traditional structures and ideas without much reprisal, as exemplified by Chole who takes to these new feminist ideas so quickly. Furthermore, a large group of women can group together outside Felicidad's house and sing a song praising feminist beliefs without many men jeering, which suggests a degree of tolerance for their views in the metropolis. The film certainly condemns these ideas overall, but the inclusion of such elements can be read more positively or at least more ambivalently.

A conciliatory tone can also be attributed to Infante's character. At this early stage in his career Infante had not yet made firm his persona as a perfectly tough macho and in Arriba las mujeres he often comes across as a good-natured but somewhat weak man. However, he is not apathetic, like the men in the city are. He is a man of action, who sees a problem and wants to fix it. He defends patriarchy and the boundaries placed on women at this time by claiming that he wants to see Chole reject feminism because he loves her and wants what is best for her. Thus, he uses a soft approach to defend the traditional gender roles. This suggests a degree of tolerance towards the modern which foreshadows Infante's subtle promotion of modernity later in his personal life, as well as that of some of his later characters. In fact, a role that can be attributed to his later persona is that of serving as a bridge between the modern and the traditional as evident, for example, in the 
fact that he rode a motorbike and flew a plane, yet at the same time claimed to venerate the Virgin of Guadalupe (Rubenstein 2001: 225). Additionally, his characters' attitude toward the city changes as time goes on, as he takes on more roles as urban characters in later films. This is evident in the Nosotros los pobres trilogy, made five years after Arriba las mujeres, in which his character seems to be more comfortable in the city than he is in this film.

\section{Openness and Virility in the Nosotros los pobres Trilogy}

In chapter two of this study, the Nosotros los pobres trilogy starring Pedro Infante was used as a prime example of a Mexican melodrama. Considering that the character of Pepe el Toro is Infante's most famous role, it is helpful to return to those three films and examine Infante's character more carefully in terms of its portrayal of the masculine. Rubenstein notes that the trilogy saw Infante move 'from playing a rural to an urban figure, while still representing the height of masculine perfection in appearance, behaviour, and character' (2001: 215). This transition of Infante's character from a small town to the big city can be seen as an attempt to bridge the real rural/urban divide in Mexico, reassuring lower-class viewers that they do not have to lose their identity as 'authentic Mexicans' (specifically authentic Mexican men) in adapting to the modernity of the city.

According to Anne Doremus, Nosotros los pobres 'reassured males of their gender superiority' (2000: 42). This is because of the system in place outlined already in which the Mexican state encouraged a strong masculine identity associated with power and control in order to bolster its standing (Berg 1992: 107). The film consciously reaffirms the state's ideology in that the character of Pepe seems to embody a response to many of the fears about masculinity that prevailed in Mexican society. As Irwin remarks, at the time 'there were clearly preoccupations about the savagery and destructiveness of lowerclass masculinity'. This was because 'barbarous lower-class men exhibited truculent aggressiveness and menacing sexuality'. Furthermore, Irwin continues, 'there were also grave fears about upper-class refined masculinity, which, in fact, seemed at times not to be masculine at all, but now decadent, effeminate, and by implication homosexual' (2003: 60, 115). This concern about upper-class masculinity is reflected in Arriba las mujeres, in which the upper-class men were more apathetic and more easily emasculated by the women's insubordination than the lower-class men. The fact that Chuy and his fiancée's father made plans to fight against the women's defiance portray them as more active figures, especially when contrasted with the passive and unprepared attitude of the men 
in the city. However, in the Nosotros los pobres trilogy Infante works more clearly as an in-between figure, taking the best (and avoiding the worst) from both extreme versions of masculinity, embodying a soft kind of lower-class masculinity. His character Pepe is far from exhibiting the effeminate 'refined masculinity' which Irwin refers to, but neither is he completely uncivilised or barbaric - a cautious, balanced masculinity is maintained. While an element of savagery is evident in the lower-class characters, Pepe and some of his friends are presented as tamed 'savages' who are overall responsible and constructive members of Mexican society. Doremus writes that the depiction of Pepe 'El Toro' in Nosotros los pobres 'emphasised traits (devotion to family, community and work, integrity, valour, stoicism, perseverance, etc...) that would be important in avoiding the social disintegration that could result from immigrants' sudden contact with so-called “modern" society' (2000: 42). In this way, Pepe is an instructive character, teaching audiences that living in the city does not have to be a 'corrupting' experience.

Numerous examples of traditional strong family bonds finding a place in the urban context appear in the trilogy, particularly through Pepe's character. As a mostly exemplary Mexican man, Pepe clearly loves his mother. This devotion is seen at its purest when he sells his much-prized medal so that his 'jefecita' can have a coffin after she dies. His loving (and lovable) nature, as an example of a 'perfect man' from the lower classes, is evidenced by songs like 'Amorcito corazón' and 'Las mañanitas'. 'Amorcito corazón' is a love song to his girlfriend, while 'Las mañanitas' is a birthday wish to his adopted daughter. However, as one would expect, Pepe also has traditional views on the role of women. In the song 'Ni hablar mujer' he emphasises that a proper woman will excel at household duties, as he sings: 'Qué bonita es mi mujer, / qué bien sabe cocinar, / y es muy hacha pa' coser / y pa' planchar'.

In the same song his wife, Celia 'La Chorreada', describes Pepe as a man who 'es muy trucha pa' chambear / y pa' comer'. In a similar way to Pepe's song lyrics about her, Celia's lyrics reduce her man to two male stereotypical qualities: working and eating. Pepe is a hard-working man and his carpentry a suitably traditional and masculine occupation that produces a clear end product for Pepe to show as a result of his physical labour. This is in contrast to the women who do not work. One woman whose main concern in life seems to be flirting with Pepe is given the nickname 'la que se levanta tarde'. Pepe does not allow himself to respond to her advances. As a desirable male who is intended as a model for male viewers and an idol for female viewers, Pepe is never shown sleeping late or being lazy. These qualities show that Pepe and his friends have not been corrupted by the city's temptations, further suggesting that Infante functions as a 
bridge between the rural and the urban as well as appeasing widespread preoccupation that the city was eroding long-established beliefs.

However, it is important to note that Pepe displays some of the more primitive qualities of lower-class masculinity, which are less desirable for a Mexican society transitioning to modernity. For example, despite his generally loving nature Pepe has a violent side. In what is possibly the most disturbing scene of the trilogy, he tortures a 'bad' inmate, depriving him of an eye, until he confesses to a murder. This is portrayed as justifiable because Pepe has noble motivations for his behaviour and his violence allows truth to triumph over lies, the ultimate goal of all melodramatic works. His fighting also proves that he is an exceptionally manly character. In a jail cell with three men, he is able to fight off two of them at one time before dealing with the more sinister man who is no match for Pepe's (supposedly righteous) anger. His inclination to misuse his strength extends to the domestic sphere when he slaps his daughter Chachita. In the film's worldview this reactionary act is negative, as Pepe regrets it and later makes amends by helping Chachita celebrate her birthday. Doremus believes that this violent incident serves to show Pepe's sincerity:

The viewer is inclined to forgive him (as Chachita does) because it is clear that he reacted out of a profound anger and regret at not being able to tell her the truth about her mother, and because he immediately repents by pounding his hand against the door until it bleeds. (2001: 175)

Pepe does all that he does authentically and passionately, which makes him endearing. It is hard to dislike Pepe at any time, even when he is acting violently, because it is clear that his intentions are always good.

As intimated by these examples from Nosotros los pobres, all three films encourage socially acceptable ('responsible') violence as an appropriate part of being a man. They condone measuring this proof of 'manliness' against other men, in both formal and informal settings. An example of a formal situation in which men can show their physical strength is in the sport of boxing, where a controlled environment allows for a display of violence considered acceptable by society. According to Jeffrey T. Sammons, at its core boxing is 'a primitive, dangerous sport, nothing more nor less than two men hitting each other' (1988: xix). Boxing is a way that upper-class masculinity can incorporate primitive, 'authentic' manliness in order to improve its tainted reputation. The sport provides a legitimate opportunity to show off the hard, impenetrable male body; to demonstrate men's superior physical strength and stamina; and to reinforce the lack of homosexual desire between men and counteract the claims which Irwin refers to that men in the city have become too effeminate (2003: 115). 
This sport is featured prominently in the third film of the trilogy, Pepe el Toro (1953). Like the earlier two films, Pepe el Toro suggests that certain potentially tragic forms of violence, such as fighting in the sporting arena, are acceptable for men to participate in. Its emphasis is not surprising, considering that part of Infante's public image was as a 'physical' man so the boxing motif gave him a chance to showcase that part of his image. By the time Infante filmed Pepe el Toro he had developed an impressive physique and his fictional counterpart's interest in boxing allowed him to show it off: he is seen shirtless in this film with more frequency than in the first two instalments. For Infante playing a boxer not only offered him this opportunity to show off his body and strength, it also provided him with another exciting, manly activity to sample and for his fans to see him engaging in. Pepe's new skill reinforces Infante's active image that had already been established both in his life and his films.

As if to underscore the danger inherent in a display of manliness like boxing, in his first public fight Pepe accidentally kills his close friend in the ring. This deeply affects Pepe, who will not box for a time and feels a responsibility to his friend's widow. Pepe's sensitive reaction to his friend's death suggests that dealing with and displaying emotion can be an acceptable way for men to honestly deal with difficult situations, in contrast to the idea which Sydie mentions that only women should be in touch with their emotions and show compassion and tenderness (1994: 3). Of course, the unashamed embracing of emotions can prove destructive as well, such as is seen with the profound anger that leads to Pepe's eye-gouging fight in the jail. His emotional character ties into the sincerity that Doremus mentions in regards to the example of Pepe slapping Chachita and then punishing himself by hurting his hand. His character shows a refreshing authenticity. According to Doremus, in Nosotros los pobres 'tears were emphasised as a means of coping with the many difficulties the poor encounter' (2000: 40). The most unexpected and awkward example of a character crying in these films is Pepe, although it should be noted that he only ever sheds tears at times of great seriousness. De la Mora confirms that the actor 'distinguishes himself from his contemporaries by his cathartic sequences where he bursts into authentic, impassioned tears' (2006: 12). As MacKinnon notes, a sensitive male character could be 'a fantasy escape from patriarchal male roles' for the male spectator (2002: 53). This reference to a 'fantasy escape' calls attention to the potentially destabilising elements of such a character if his behaviour were to become more acceptable in society at large.

The best illustration of Pepe displaying tender emotion is the scene from Ustedes, los ricos described in the second chapter. Pepe cries in anguish over the loss of his son, 
with several close-ups of his face shown. The almost intrusive shots are notable because of the significance of the close-up, often seen in film's depictions of female stars and thus hinting at a feminisation of Pepe. Dyer writes that because such a shot removes all surrounding characters and items from the screen and provides a unique, perhaps disconcerting, closeness, the close-up reveals to the viewer 'the star's face, the intimate, transparent window to the soul' (2004: 10). Showing Infante through close-ups in this way means that he seems to be offering his 'true self' to the viewers. As Judith Brown writes, 'to behold an image in close-up is to possess it, to boast the sort of access that suggests intimacy with the object, even if the close-up represents only a fragment of the original' (2010: 111). Close-ups, therefore, suggest openness and that the person being filmed is open to being gazed at closely and profoundly. Unlike the stoic males frequently on the screen in the 1940s, such as Pedro Armendáriz, Infante's character is not closed and repressed in his emotions. This is especially notable because Pepe clashes with the cultural expectation that men were supposed to be impenetrable and in control of their bodies and feelings (Lehman 2007: 113). As further evidence of Pepe/Infante's alignment with the feminine in this scene, Pepe is not being strong in a time of tragedy. The woman - his wife - is in this case the character trying to be brave, appealing to religious platitudes to try to comfort her husband. Pepe, in contrast, is the weaker individual, asking why this would happen. This scene seems to offer a small amount of hope for masculinity in Mexico at this time, because it insinuates that crying and showing emotion may be appropriate for men after all.

Also of note in the 'feminisation' of Pepe/Infante in this trilogy is Pepe's display of motherliness in his parenting of Chachita. Ann Dally writes that the term 'mother' can be understood as the care "which may be provided by a mother but may come from elsewhere', including from a male (1982: 190). Dally continues her argument for a broader definition of motherhood in the following way:

Motherliness is a human quality and by no means confined to women. The use of the phrase 'maternal instinct' is often used by those who wish to assert that only women should care for children or that the details of childrearing are beneath the dignity of men. In fact, many men have motherly qualities and many more could develop them if society and circumstances would permit it. (1982: 200)

Therefore, it is clear that maternal feelings and behaviour are not limited to women. The idea that they should be is reflective of a society that values different gender roles.

Dally's assertion that motherliness is 'by no means confined to women' is demonstrated in all three films. Pepe, by necessity, takes on the role of both father and mother to his niece, becoming a sort of 'mother father'. Through this he demonstrates 
that, instead of only being threatening, distant, and inaccessible, a father can also have qualities traditionally associated with women, in particular those of a loving mother. Sometimes the stern father persona and the tender mother persona conflict oddly with one another. The earlier example of Pepe lashing out at Chachita one evening shows him in his role as a protective and authoritative father figure. He demonstrates his dominance by wounding her physically, punishing her. However, the following morning he leads their friends in singing Chachita a birthday song outside her window, showing his affection for her. This delight in singing to her can be considered feminine. Howe and Hirschfeld maintain that singing to a child, often in the form of lullabies, is predominantly associated with women (1981: 307). Because of his propensity to being affectionate with Chachita, she loves him and is devoted to him. For example, when she is tempted to become too romantically involved with a young man, her father's cautions prevent her from acting inappropriately.

It should, however, be noted that Chachita is not his biological child. Pepe's sister, Yolanda 'La Tísica', has given Chachita to him because she is a prostitute, which makes Pepe only her uncle. This may, in some way, make it more acceptable for Pepe to be slightly atypical in his parenting. It also means that her mother has placed much trust in someone else to give her nurture, an inherently risky move. As a prostitute, it is evident that Yolanda does not have the same choices available to her as these parents, but she still has decided to entrust her daughter to her brother. She expects him to be both father and mother to Chachita, as there is no female figure present in Pepe's life at the beginning of Nosotros los pobres (except for Pepe and Yolanda's mother, who cannot engage with the world), and Pepe endearingly succeeds in the task of balancing the masculine and the feminine in his parenting. This success further implies that masculinity and femininity are not mutually exclusive and a fusing of the two may best suit modern life.

Paz's well-known attempt to redefine Mexican identity in terms of a more feminine, open attitude that could be penetrated by foreign influences ${ }^{14}$ further brings the Nosotros los pobres trilogy in line with one of the main features of Golden Age Mexican films: their role in aiding audiences to transition to the new society. Doremus claims that the portrayals in Nosotros los pobres exist 'in order to promote social harmony and

\footnotetext{
${ }^{14}$ Paz writes the following about the struggle for openness in Mexico: 'When we shout "Viva México, hijos de la chingada!" we express our desire to live closed off from the outside world and, above all, from the past. In this shout we condemn our origins and deny our hybridism. The strange permanence of Cortés and La Malinche in the Mexican's imagination and sensibilities reveals that they are something more than historical figures: they are symbols of a secret conflict that we have still not resolved. When he repudiates La Malinche - the Mexican Eve, as she was represented by José Clemente Orozco in his mural in the National Preparatory School-the Mexican breaks his ties with the past, renounces his origins, and lives in isolation and solitude' (1985: 86-87).
} 
modernisation' and that the urban melodrama 'helped to explain to Mexicans the societal changes resulting from modernisation, and offered models of conduct to deal with those changes' (2000: 47, 2001: 5). The slight opening up of male identity may be a strategy to encourage incorporation of acceptable male difference, particularly that associated with the lower classes, into Mexican society. The reconfiguration of the place of the lowerclass man results in an uneasy compromise between the traditional and the modern that does not openly question important archetypes of male sexuality while still allowing for the possibility of a softer masculinity.

\section{Infante's Buddy Films as a Model of Urban Homosocial Bonding}

In the Nosotros los pobres trilogy Infante's character shows himself to be accepting of the city and its modern ways to some extent. Infante's portrayal of Pepe is just as appealing as that of Chuy in Arriba las mujeres, but in the trilogy his character has an edge to him that allows him to survive in the harsh urban surroundings. This section looks at two of his later films and argues that they present a further evolution in the kind of character that Infante portrays, especially in his attitude toward urban masculinity. These films serve as a logical completion of Infante's 'character arc' which started with Chuy and progressed through Pepe. In them he is accustomed to the city and participates with enthusiasm in its symbols of modernity, most notably in his ambition to become a motorcycle policeman. His character has also found ways in which to maintain a certain stalwart masculinity and machista elements, although it proves to be challenging at times.

These comedic films, A toda máquina (1951) and ¿Qué te ha dado esa mujer? (1952), centre on Pedro Infante's friendship with Luis Aguilar. The two connected films have fairly simple plots and serve as a vehicle for showing a friendship between two men in the city. In A toda máquina Pedro is homeless and Luis helps him improve his life. Although Pedro annoys him, they end up bonding and become close friends. They both want to better one another in being motorcycle policemen and compete with each other in this field, leading to displays of motorcycle tricks. By the beginning of the second film they share everything, including lodgings. ¿Qué te ha dado esa mujer? picks up where the first film ends. Its conflict is that the friends have promised one another that they will not marry, in order that women will not come between them and harm their friendship, but their girlfriends keep hindering their resolve to avoid serious heterosexual relationships.

The theme of this series and the appeal of its two central characters are more important than the events that actually take place in it. As the dominant theme is the friendship between the two men these films are best classified as 'buddy films'. Dyer 
defines this film genre in the following way:

The buddy movie presented a male-male relationship that was composed of humour, tacit understanding and, usually, equality of toughness between men. This relationship was constructed by a disavowal of the very thing that would appear to bind the men together-love. The elements that compose the relationship actually effect this disavowal—badinage as a way of not expressing serious emotions, silent communication as a means for not articulating or confronting feelings, toughness as a sign that one is above tenderness. (1993, 2002: 103)

In this definition Dyer refers to the implicit assumption of the worldview present in buddy films: it is difficult to be sure where friendship ends and romantic love begins. De la Mora refers to it as 'the ambiguous continuum between homosocial bonding and homoerotic desire' (2006: 98). This leads to men having to be deliberate in their dealings with other men in order to make sure that their relationship does not slip into (or is not seen as slipping into) a relationship that is no longer societally appropriate between men.

As these films centre on the bond of friendship between two men, often referred to as homosocial bonding, some general background on the theoretical concepts at play is essential. Alan Bray, writing about male friendships in Elizabethan England and the problematic nature of affection between men, states that 'there is always a potential ambiguity about intimacy between men' (2002: 350). In both historical friendships and fictional relationships, there exists a thin line between friendship and romance. This often leads to men feeling that they have to prove their heterosexuality to other men, especially if they have a close bond. Sharon R. Bird writes that 'homosocial interaction, among heterosexual men, contributes to the maintenance of hegemonic masculinity norms by supporting meanings associated with identities that fit hegemonic ideals while suppressing meanings associated with non-hegemonic masculinity identities' (1996: 121). In other words, the fear of homosexuality is a catalyst for negative male behaviour and the privileging of patriarchy. As Irwin notes, 'the fact that a man can be fucked means that his masculinity is not essentially sacrosanct and is open to constant challenge from other men' (2003: 195). Close male friendships often bring with them a chauvinist attitude, as such beliefs are reinforced between men as they try to demonstrate that they are more virile, powerful, and overall manly than the other-to put it crudely, to prove that they cannot 'be fucked'.

In the introduction to Mexican Masculinities, Irwin asserts that while 'homosocial relations between men $[\ldots]$ are highly contentious $[\ldots]$ at the same time, they are essential to the construction of the Mexican nation' (2003: xxvii). If such relations are at the heart of the construction of Mexico, they are clearly indispensable to a complete view of 
masculinity and its correlation to modernity. They are certainly central to the reconfiguration of masculinity in the Mexican post-Revolutionary context. While solidarity with other men was important, there was a concern that men being too emotionally close to each other could lead to the spread of homosexuality, a 'deviance' that had been becoming more visible since the early part of the twentieth century and which resulted in what Irwin calls the Mexican 'homosexual panic' of the 1940s and 1950s (2003: 187). According to Irwin, Mexican masculinity 'from the forties became an even more troublesome topic than it had been in the past' due to 'the growing consciousness of the inability to make a pure and distinct separation between virility and effeminacy, between homosocial and homosexual relations, particularly in a national context' (2003: 223). Men who are less than 'manly' were seen as threatening the postRevolution political status quo. ${ }^{15}$ Infante, as an exemplary and notoriously heterosexual man, can serve as an example of how men should behave with other men in the city environment, where unacceptable forms of manliness might more easily crop up than away from the city. He is able to show homosociality in an urban context while avoiding anything too reminiscent of homosexuality, as, of course, homosexuality threatens men's impenetrability as well as men's 'natural' position as dominant and in control over women.

Héctor Domínguez-Ruvalcaba views the two Infante films with these concerns in mind. He notes that Pedro and Luis's relationship 'blurs the distinctions between categories that define love and friendly relationships, as assumed by social standards'. Domínguez-Ruvalcaba argues that the affectionate friendship is, however, acceptable precisely because it offers an excuse for them to display their prowess as men and allows them to 'reasonably' persist in their misogynistic attitudes and behaviour $(2007: 87,89)$.

De la Mora also analyses these two films. He writes that his 'interpretations are informed by the filmic codes that introduce sexual ambiguity into the emotional, and erotic, dynamics between cuates' (2006: 89). There are certainly elements of a queer reading in his analysis. For instance, de la Mora writes the following:

Infante's buddy movies focus on achieving the unification of the male couple and on smoothing out the tensions that threaten to separate them. [...] The bond between men is what is valued above all. (2006: 88)

In addition to the homoerotic elements that de la Mora emphasises in their relationship, like Domínguez-Ruvalcaba he also observes a misogynist undercurrent (2006: 91).

\footnotetext{
${ }^{15}$ Steve Cohan makes this same connection in his comments on U.S. ideology on masculinity as presented in Hollywood film in the 1950s, when men considered weak (homosexuals, Communists) threatened U.S. identity and conviction during the Cold War (1997: 6-7).
} 
This chapter's perspective on these films comes from a similar position to these critics in that it is also concerned with masculinity in Mexico. There is certainly validity in focussing on the queer potential of the films that Domínguez-Ruvalcaba and especially de la Mora emphasise. However, in keeping with this chapter's focus, this section concentrates on the connection between a certain (precarious) definition of masculinity espoused by the two films and the increasing signs and symbols of modernity in Infante's films and characters. The ensuing analysis emphasises the suggestive potential of the image of Infante embracing the city, arguing that like Nosotros los pobres it provides instruction and reassurance for viewers in regards to the city. This guidance mostly pertains to how relationships between men and women can be safely navigated within modernity and how a balanced urban masculinity can be achieved.

These two films inform men how they should view and act toward women in modern Mexico, encouraging machista attitudes. As Eve Kosofsky Sedgwick suggests, 'in any male-dominated society, there is a special relationship between male homosocial [...] desire and the structures for maintaining and transmitting patriarchal power' (1985: 25). Pedro and Luis's main preoccupation is the supreme importance of the male relationship, as seen in their actions and intimated in their words. Understandably, they never admit to the importance of their affection for one another. One of the main activities that the pair bond over is their pursuit of women. However, as evidenced by the men's promise to each other that they will not marry, their relationships with women are of less importance than their friendship. Their steadfast friendship encourages a distrust of women and is a hindrance to equality between men and women. Domínguez-Ruvalcaba believes that women's primary purpose in the narrative is to mediate their relationship (2007: 88) and de la Mora notes that 'each man uses women to get the attention of the other cuate' (2006: 91). Therefore, in the worldview of the films women function as both sexual objects and reminders of male superiority. Domínguez-Ruvalcaba considers that this 'misogyny reaffirms Luis and Pedro's machismo' (2007: 89). Women's main purpose is to maintain the existing order and they have little value outside of masculinist ideology (de la Mora 2006: 88, 95). Women's place in the city is similar to their social position in the countryside, which is a reassurance for men of their own privileged position within Mexican modernity.

The title of the second film is also the title of a song that Pedro and Luis sing to each other. '¿Qué te ha dado esa mujer?' further underscores the essential role of homosociety to Mexican societal order in the 1950s. De la Mora writes that 'this unforgettable duet performance [...] stages the glories of male camaraderie couched as a 
plaintive lament over a female heartbreaker' and contains 'barely articulated homoerotic tensions between Luis and Pedro' (2006: 96-97). This song appears in the film after Luis has abandoned Pedro because of a woman, leading Pedro into a state of depression and jealousy. In it, Pedro asks, ¿¿Qué te ha dado esa mujer que te tiene tan engreído querido amigo? Querido amigo, yo no sé lo que te ha dado'. Pedro tells his 'querido amigo' through the song that, when it comes to the woman who threatens their friendship, Luis's 'destino es comprenderla y olvidarla'. De la Mora believes that these 'lyrics emphasise and valorise the primary male bond associated with purity, transparency, and naturalness in opposition to the mysterious origins and dangerous effects women exert over men when they fall in love' (2006: 97).

As well as competing over women, they try to better one another in other areas, such as motorcycle demonstrations and tricks. The competitiveness between the two characters is a constant attempt to prove their masculinity to one another and to other men. Domínguez-Ruvalcaba notes that their antagonism is a deliberate show and the rivalry functions as an essential part of their homosocial relationship. He writes that 'competition and jealousy consolidate the exclusivity of this relationship that even neighbours and coworkers celebrate as an intense friendship, thus legitimating this homosocial intimacy' $(2007: 91,88)$. All this is related to maintaining gender relations and their correlation to modernity.

Same-sex friendships and relationships may have the potential to offer a levelling platform for men from different class backgrounds, which will be needed in the city context. ${ }^{16}$ This is pertinent to the socio-political context considering that one of the stated aims of the socialist-influenced Revolution was equalisation. Therefore, this may suggest a representation of the continuation of Revolutionary ideals in these films. The relationship between Pedro and Luis defies the confines of class and values mutual respect as equals as part of a mature relationship. Male friendships like the one between Luis and Pedro offer a space to share experiences and thoughts. Luis comes from a wealthy family, rarely seen without a suit, while Pedro, mirroring the origins of the actor, is poorer and unrefined. Luis, perhaps taking into account Pedro's less refined background, originally intends Pedro to be his manservant and to live with him in that capacity. De la Mora

\footnotetext{
16 This idealistic view is seen in E.M. Forster's novel Maurice (1971) in which the author implies that homosociality and especially homosexuality have a potential to offer a platform for equalisation. At first Maurice thinks that the groundskeeper Alec is less than him and does not give him a second thoughtbefore Alec pursues him and shows him a different world removed from the repression caused by religion and class issues that he experienced at Cambridge. Like Pedro and Luis's, the relationship between Maurice and Alec defies the confines of class and values respect as equals as part of a mature relationship (Toda 2001: 142-43).
} 
believes this means that Luis attempts to feminise Pedro. He argues that Pedro accepts this feminisation, using the examples of Pedro wanting to have someone to take care of him and becoming sullen when Luis makes a woman more important than him to support this claim (de la Mora 2006: 91-92). However, it seems that Pedro frustrates Luis's attempts to treat him as an inferior, challenging him with displays of manliness and exhibiting an unwillingness to submit. Pedro is searching for a companion, not a master.

Overall, these films provide a model for modern Mexican men of how to conduct themselves in a city environment, particularly in relationships with other men. By now, Infante's character is very comfortable in the city and embracing it more completely. Even the use of the word 'máquina' in the title of the first film evidences how far Infante has come, referring to the machinery which is closely associated to modernity and the city. A number of the promotional images portray Infante on a motorbike, letting audiences know that they will be able to see something new and different-but still very much in character-in this film. They show how to be a good male friend without ever falling into the queer category. In this sense the films share a similarity with earlier Infante films discussed in that it displays an uneasy compromise or tension as it tries to satisfy all sectors of society without deeply or openly challenging the established norms. Both traditional and modern phenomena are combined but there is no radical questioning of masculinity through the representation of male friendship. In order to maintain this machista masculinity, the films suggest that class boundaries in the city might need to be slightly more flexible. The ending of A toda máquina concludes with Luis and Pedro laughing together and confirming to one another the importance of their friendship, as Luis admits to Pedro that 'siempre había buscado a un amigo hasta que por fin lo encontré en usted'. The goal of both films is to provide guidelines about how to not be contaminated by upper-class masculinity, 'decadent, effeminate, and by implication homosexual' according to Irwin (2003: 115), while living in the city and making connections with other men. Through bridging social differences between the two friends they diffuse the tension caused by modernity and clearly help the dominant message of the Revolution.

\section{Conclusion}

Infante is a cinematic figure of transition that corresponded to the changing face of Mexico, particularly in regards to the rapidly increasing urban migration of the 1940s. His biographical detail as a man who moved from rural poverty to urban modernity is particularly meaningful, especially considering that he never lost his 'authentic' 
manliness but simply adapted it to the city. Infante and the fictional characters that he played provide an example of modernity's effect on the masculine individual and offer a comforting image of gradual adaptation to the city and modernity. 


\section{CHAPTER 5 \\ WOMEN, MOTHERHOOD, AND MODERNITY}

This chapter probes the issue of how two specific female characters from classic Mexican films intersect with modernity. First, this chapter will provide some background on views on women in Mexico, particularly focussing on the primary role of women as mothers and the ideology of marianismo. In the context of Mexican revolutionary society the traditional role assigned to women was that of motherhood. This role entailed a nationalist dimension epitomised by the 1930s and 40s Mexican government slogan 'Haz patria: Ten hijos' (Foster 1997: 235). This ideology was reflected in many films from this time period and was part of the wider representation of women in popular fiction. One of the most famous melodramas from this country's Golden Age of Cinema is the 1945 film Las abandonadas. In this film, which is often considered a maternal melodrama, Dolores del Río plays a fallen woman who still manages to succeed as a mother. Despite her flaws, she is committed to motherhood. An analysis of this film will illustrate the expected character traits of an ideal mother in the Mexican society of the 1940s while also considering some of the contradictions in the representation.

Of particular interest to this study is the femme fatale character and her relation to modernity. Fernando de Fuentes and Miguel M. Delgado's 1943 film Doña Bárbara contains many features that touch upon significant issues related to femininity, feminism, and female identity. In addition, it opens up a number of avenues for theorising the wellknown Latin American dichotomy of 'civilisation' and 'barbarism' in gendered terms. Several of Doña Bárbara's characteristics would have made her a 'bad mother' according to the dominant views on gender and parenting in the 1940s. In the ensuing analysis, a look at María Félix's performance of this character will analyse the ways in which she has failed as a mother, and the significance of such a representation.

\section{Women in Mexican Society}

The status and role of women in Mexican society during the time of the Golden Age of Cinema was undergoing a period of transition. Joanne Hershfield explains the situation:

Before 1930, women's position in Mexican society had been narrowly circumscribed by the family, the church, and sexual function. However, in an era of rapid industrialization, women had to be addressed as members of the workforce and as consumers. (1996: 29)

As society changed, so did the role of women, to some degree blurring the boundaries between the worlds traditionally assigned to each gender. The response to this was an 
attempt to bolster patriarchy by the Mexican state, which Berg calls 'a reciprocal ideological agreement between the individual male and the Mexican state'. As outlined in the previous chapter, this allowed men to enjoy a superior position in society to women (1992: 23).

Paz's classic essay on the Mexican condition entitled The Labyrinth of Solitude, originally published in 1950, provides a description of the typical Mexican male view of Mexican woman. The renowned Mexican intellectual writes the following:

The Mexican considers woman to be a dark, secret and passive being. [...] The Mexican woman quite simply has no will of her own. Her body is asleep and only comes really alive when someone awakens her. She is an answer rather than a question, a vibrant and easily worked material that is shaped by the imagination and sensuality of the male. (Paz 1985: 36-37)

Thus, Paz stresses the Mexican male-centric conception of women as passive objects who only acquire some agency through male intervention. An implication of this view is that women are open to accept any male intervention passively, as they need it in order to acquire a sense of being - even if their being is defined solely in terms of men. As Marit Melhuus notes, such male conceptions of female identity also result in a Manichean tendency to classify woman as either decent or indecent and 'good' or 'bad', which contrasts with the various degrees of acceptable maleness assigned to men (1996: 231). Paz also draws on the idea of women being open rather than closed. Paz refers to the word 'chingar' to describe the Mexican view of women:

The person who suffers this action is passive, inert and open, in contrast to the active, aggressive and closed person who inflicts it. The chingón is the macho, the male; he rips open the chingada, the female, who is pure passivity, defenceless against the exterior world. (1985: 77)

As Irwin puts it, 'female inferiority is rooted in a woman's sexual organ, which is fucked' (2003: 195). Since a woman is penetrable in a physical sense (a 'passive being'), it follows that her identity needs to be defined by her sexual other and imposed on her. Therefore, in Mexico a woman was equated with being passive instead of active (Lindauer 1999: 46).

In Mexico at the time of the Golden Age of Cinema, views about female sexuality were often split into extremes, drawing on the historical or mythological figures of La Malinche and the Virgin of Guadalupe. On one hand, the excessively sexual woman was the traitor of Mexico and Mexican values. In the mid-twentieth century, this sexually transgressive woman was often the prostitute, particularly in fiction. On the other hand, the virgin mother was the true essence of Mexican motherhood, at least according to some. Harkening back to the Virgin Mary such a figure was pure, submissive, and 
devout. ${ }^{17}$ The images of the 'devil woman' and the saint offer little subtlety, but created two complete opposites. This way of thinking encouraged seeing women in terms of a clear-cut binary opposition, with no room for an unclear middle ground where women could not be easily labelled.

The representation of women in post-Revolutionary Mexican fiction was motivated by these considerations. Cinema became one site in which to search for women's identity and place and to articulate a perspective on being female (Hershfield 1996: 30). Doremus notes that in Mexican film 'it is almost always the male who embodies "Mexicanness", as it is his identity that is being searched for, with the women only functioning as a help for finding his (and, by implication, Mexico's) identity (2001: 7). Therefore many of the depictions of women are prejudiced, as they in part reinforce ideas about women being passive as opposed to men.

\section{Images of Regression in Las abandonadas}

García asserts that 'Mexican culture challenges the cult of the macho with the cult of the mother as a supreme and untouchable authority' (1995: 154). Therefore, being a mother was the most culturally acceptable role for women at this time. According to Margaret A. Lindauer, 'in postrevolutionary Mexico, one of the most significant social expectations of married women was to bear children, and women were understood to carry an intense yearning to procreate and nurture' (1999: 20). Additionally, she writes that 'motherhood was entangled in Mexico's postrevolutionary concern for social stabilization' and 'the family was the ideological site where the passive-female/active-male distinction was entrenched, with the stereotypic Mexican wife/mother not only ancillary to the absolute authority of the husband/father but also to the nation' (1999: 22, 24). She continues by adding the following:

In the midst of chaos and instability, the mythically steadfast family became a pervasive symbol for stabilizing the country. In the mythic family, the ideal woman excelled in the domestic sphere, nurturing the family, while the paradigmatic man attended to public affairs. [...] The symbolism of a paradigmatic husband/father, centre of both family and society, with a wife/mother who provided all of his domestic needs, including a throng of children submissive to his paternal direction, comprised an analogy for a society that submitted to a paternalistic national government. (1999: 23)

In such a society, women were considered to be naturally maternal. Marianismo is the ideology that supports these social expectations, with religious sentiment used to support a patriarchal ideology. Although this concept was alluded to in an earlier chapter,

\footnotetext{
${ }^{17}$ For an in-depth discussion of these themes, see Hershfield (1996: 13-34).
} 
a little more detail on it is necessary for understanding Las abandonadas. David Sequeira writes the following in regards to what is expected of a woman who adheres to the beliefs of marianismo:

A mariana's ideal behaviour encompasses dependence, subordination, responsibility for all domestic chores, and selfless devotion to family and children. She is also expected to accept and tolerate certain behaviours from her man - aggressiveness, sexual infidelity, arrogance, stubbornness, and callousness. [...] The mariana needs to follow Mary in her purity, virginity, and humility and to accept her fate as mother and wife and all that this entails. (2009: 30-31)

Simone de Beauvoir writes that, in traditional thinking, 'it is through motherhood that woman fully achieves her physiological destiny; that is her "natural" vocation, since her whole organism is directed toward the perpetuation of the species'. If a woman 'is not a complete individual as a wife, she becomes it as a mother: the child is her joy and justification' (2010: 524). As Sarah L. Franklin explains, the implication is that motherhood absolves a woman of original sin, in a similar way to how work outside the home is considered man's destiny (2012: 22). By bearing children she is accepting her supposed fate as a woman to suffer through the pain of childbirth and be submissive to her husband. Mothering becomes her full-time occupation. If a man is a father, then he is also something else in most cases. Being a father is very rarely seen as a man's defining role, as a man is allowed a more diverse identity. For instance, he can be defined by his work, his friends, and his family life. In fact, it is generally expected that he will put his work above his responsibilities as a father. If a woman is a mother, that is often her fulltime role, and her only source of identity as a person. Abby Arnold refers to this as 'the unachievable myth of the perfect, all-available Mother' (2003: 1).

Mexican Golden Age films show many long-suffering mothers who practice selfdenial for their family, especially their children. Tuñón observes that 'en el cine mexicano las madres no deben mostrar su enojo sino, tan sólo, sufrirlo: el sufrimiento es la característica fundamental del sentimiento materno' (1998: 192). This is because, in Monsiváis's opinion, 'before the essential message of all cinema was clearly understood (that is to say, the irrefutable power of modern life), the film industry exalted the repression of instincts in favour of moral servitude' (1995b: 49). Instead of trying to deal with complex emotions or even being aware of them, these characters have to deny them for the sake of their husband and children, which in time becomes an ingrained habit.

Las abandonadas (1945), directed by Emilio Fernández and starring Dolores del Río, is a prime example of a Mexican film melodrama which shows a mostly traditional view of women in the face of modernity and exalts motherhood. This film is often 
considered a maternal melodrama, because of its emphasis on the merits of motherhood. Las abandonadas offers a warning against 'bad' female behaviour while at the same time showing a possibility for redemption for imperfect women within the context of motherhood. Nevertheless, it is evident from film melodramas that a single woman can still be a cinematic heroine, as a character who fights against the injustices of life and overcomes the prejudices of society. In Mexican cinema the abiding, transcendent love of a mother was illustrated through imperfect mothers like Margot in a sometimes more forceful way than through the exemplary mothers played by Sara García, which were less complex characters. This is confirmed by Linda B. Hall, who writes that during her Mexican period del Río 'seemed to provide [...] "projections" useful to a society still in transition after its bloody revolution of 1910-1920' (2013: 3).

Las abandonadas is based on the structure set out by Madame X, a 1908 French play by Alexandre Bisson that was later turned into a number of popular films. Viviani outlines the basic plot details, noting that the mother's child 'carries within him the salvation and progress of a society', usually a society that has experienced some kind of upheaval. She frequently gives up her child willingly, for both his benefit and the benefit of humankind. Viviani then adds the following:

The mother gives up her child to insure him an education, a moral training that only a well-placed family can provide him. The mother's first reaction to the birth of her child is to reject him [...]; she then accepts him briefly, then realises that her single state can only lead the upbringing process to failure. (1987: 94)

In Las abandonadas, Margot leads an eventful and melodramatic life, set against the backdrop of the Mexican Revolution. The film starts with an innocent and jubilant Margot, as she celebrates her recent marriage. She soon discovers that her new husband is already married, and thus is left on her own and has to resort to prostitution. Margot gives birth to a son in the brothel. His name is 'Margarito' and he becomes the best part of her life. Her life improves once she meets a wealthy general, played by Pedro Armendáriz, who marries her and is devoted to her. However, he is in fact an imposter who has assumed the identity of a general who died in one of the many skirmishes during the Revolution and is using his position to rob the wealthy. Once his true identity is revealed Margot is sent to prison for appearing to be complicit in his crime. This means that she has to give her son to the orphanage, where she decides to leave him after she is freed from jail. Margot prostitutes herself so she can send money to the orphanage for her son's education, and eventually he becomes a lawyer. The film ends with Margot seeing her son defend a woman against a murder charge, which gives her pride in what her son 
has become. However, she never reveals her true identity to her son, keeping him from the disappointment of having a prostitute for a mother.

Las abandonadas is a film that in many respects follows the tenets of both Mexican Revolutionary discourse on women and marianismo, supporting the stabilising goal of the 1940s Revolutionary government. This is most clearly illustrated in the fact that the protagonist is a mother who sacrifices everything for her son. Hershfield confirms the film's adherence to the Mexican state's goals, writing that 'as Margarita, del Río embodied post-Revolutionary national and gendered transformations in the role of a national (female) citizen who sacrifices herself for the welfare of the new Mexican nation, represented in the figure of her son' (2000: 64-65).

In her role as a mother Margot is able to indirectly affect society through her son, although she has to sacrifice everything in order for him to achieve the necessary success. This ultimate sacrifice is fitting, considering that Melhuus writes that suffering 'becomes the mark of motherhood' (1996: 247). Part of the reason she is devoted to making these anonymous sacrifices for her child is because he is male and the advantages that his sex gives him. Even though as a woman with a chequered life she cannot make an impact in society, through a son she can. On this topic, Beauvoir writes the following:

Because of the prestige woman attributes to men, and also the privileges they hold concretely, many women wish for a son. [...] The son will be a chief, a leader of men, a soldier, a creator; he will impose his will on the face of the earth, and his mother will share in his immortality; the houses she did not build, the countries she did not explore, the books she did not read, he will give to her. Through him she will possess the world: but on the condition that she possesses her son. (2010: 560)

This suggests that a woman can exert some power within the patriarchal boundaries imposed by society through her relationship with her son. Las abandonadas certainly suggests a partial empowerment of Margot through Margarito, although to a large extent this is really another way for the filmmakers to distil social tensions. For example, she chooses to allow him to grow up in the orphanage because she realises that he will have better chances in life if he stays there than if he goes to live with her, and this in turns allows him to become a lawyer who defends the weak and underprivileged. At first Margot is extremely resistant to leaving him in the orphanage, as her son is more important to her than all else in the world. However, she forces herself to tell Margarito, through tears: 'Tu mamá ha muerto'. By saying this, she is removing herself from her son's life and giving up her right as his mother to give him nurture and love, since in this case what is best for the child is not having his mother in his life. Because Margot leaves her son at the orphanage, he becomes successful. Although Margot does not manage to 
better herself, the money she makes from prostitution allows her to finance her son's education. As a result of her sacrifice, Margarito becomes 'un gran hombre' by the end of the film, which was Margot's dream for him. He has grown up to be a successful and decent man who can help other women not be maligned and oppressed as his mother was. His strong moral compass is evident when Margot sees him speaking before the court, defending a mother against a criminal charge. Margarito concludes his defence of the women by saying: 'Donde está una mujer, está la pureza toda de la vida. Pero donde está una madre, está Dios'. Despite not knowing his mother for most of his life and having no memories of her, because of Margot's sacrifices for him he appreciates the mother figure that his mind has created. Coincidently, Margarito gives his mother a gold coin when he sees her crying with happiness outside the courtroom, but Margot's real payment for her sacrifice is who her son has grown up to be: 'un gran hombre' who understands how sacred being a mother is. Notably, Margot does not die at the end of the film as she does in most versions of Madame X; she can bask in her son's glory for the rest of her life.

Monica Budowski, in reference to Latin American culture, writes that 'lone mothers, in particular unmarried women, are significant transgressors of social boundaries' (2005: 82). Margot is already transgressive as a lone mother, but even more so as a single prostitute mother. The fact that she is a sex worker is suggestive as it allows for the possibility of a sexually active exemplary mother. De la Mora remarks that 'sex workers who are also mothers challenge both the rigid distinction made between prostitutes and mothers and conservative criteria regarding who is fit to be a "good mother"' (2006: 30). This is because it is disconcerting to acknowledge that a mother can have sex and yet still be a good mother. Although the reality is that a woman cannot become a mother without first having sex, according to the tenets of marianismo a mother is an inherently asexual person. This makes Margot a unique character, as she works as a prostitute for much of Las abandonadas yet it would be hard for any viewer to consider her a bad mother. Margot's connection to prostitution is so persistent that she even gives birth to Margarito in a brothel. Margot does not want to be a prostitute, as circumstances force her into it, but nevertheless the fact remains that she is a prostitute and yet at the same time a good mother. This suggests that La Malinche, the deviant woman, and the Virgin of Guadalupe, the perfect mother, can exist in the same person. However, because of the binary view of women as either sacred mothers or prostitutes that was dominant at the time, the film insists that Margot is only reminiscent of the Virgin of Guadalupe; the less perfect elements of her character are merely part of the suffering that she must go through for her maternal devotion to be proven. Therefore, the character of Margot is not 
a threat to established and popular views on women, serving as an example of how Mexican cinema tended to express a masculinist vision of women.

\section{The Femme Fatale and Doña Bárbara}

If Dolores del Río is most commonly associated with the long-suffering woman, then María Félix is perhaps most readily associated with resistance to submission. She is most famous for playing strong women and 'devoradoras de hombres' (Ocasio 2010: 275). Félix is best remembered for Doña Bárbara and its title character. This film is notable because, as King observes, it 'gave Félix the image that she would repeat, with variations, over the next decade: the haughty, self-contained woman, the "devourer of men" (1990: 50). Based on the novel by Venezuelan writer Rómulo Gallegos, it tells the story of a woman who, after her boyfriend is killed and she is raped, exacts revenge on men by taking control of a ranch in a remote part of Venezuela's vast rural regions. The narrator of the film describes her in the following way:

Hoy es la dueña de casi todo el cajón del Arauca. Señora de vidas y haciendas, rebaños y sabanas. El llano la teme y la obedece. Su hermosura fascina a los hombres, y su oro compra leyes que la protegen y paga manos que por ella matan. Doña Bárbara, la temible Doña Bárbara.

However, her dominance is threatened by the arrival of Dr. Santos Luzardo, who comes from the city to claim some of the land that Doña Bárbara has stolen and with whom she falls in love. They find themselves in conflict with one another throughout the course of the film, until eventually Luzardo forces Doña Bárbara to leave her plantation.

The type of character that María Félix plays in Doña Bárbara is a femme fatale, which is defined by Elizabeth K. Menon as 'an archetypal woman whose evil characteristics cause her to either unconsciously bring destruction or consciously seek vengeance' (2006: 4). Mary Ann Doane opines that this figure is 'insistently a figure of fascination in the texts of modernity', precisely because she hinders modernity. Far from being a subversive character, Doane believes that the femme fatale is predominantly a male response to the threat of feminism. She writes that the male perspective is seen in their ending: 'the femme fatale is situated as evil and is frequently punished or killed. Her textual eradication involves a desperate reassertion of control on the part of the threatened male subject' (1991: 2-3). Despite Doane's emphasis on the questionable intent of those creating the femme fatale characters, it must not be forgotten that authorial intent and reader reception are not always the same. Femme fatale characters often hold an abnormal amount of power over men and do not adhere to society's expectations. These characteristics, regardless of the author's or screenwriter's intentions, may lead audiences 
to considering a femme fatal character as a kind of role model or sly hero. It is a figure that, although created out of sexist attitudes, clearly contains an empowering potential, as she figuratively eats the man, as opposed to the traditional male representation of women as an object to be consumed.

Doña Bárbara takes on male characteristics which allow her to excel professionally, wearing clothing associated with men and conducting herself in a 'masculine' manner in terms of control and sex. ${ }^{18}$ According to Virginia Mae Allen in her study of the origins of the femme fatale figure, this appearance arose 'from the nineteenth century conviction that personal independence and sexual freedom were masculine in nature - that is, if a woman was represented as behaving in a "masculine" way, obviously she would have a slightly "masculine" appearance' (1979: 328). Doña Bárbara is often seen with a whip in hand, rides a horse, and smokes. In the film, Luzardo is presented as the 'good guy', while Doña Bárbara displays a machismo that is destructive and immoral. Luzardo's attitude is shown as a natural extension of his being male, while Doña Bárbara's maleness is merely a façade, a masking of her true self because of a traumatic event in her life: the murder and rape that has defined her life's path. Clothing herself in masculinity is the only way she can achieve dominance over land and men (Hershfield 1996: 111). Her identity is broken, according to patriarchal ideology. Luzardo asks her, ‘¿ha pensado Ud. en el daño que a sí misma se ha hecho?’, almost becoming a patriarchal voice that is trying to convince her of the error of her ways. As Dyer notes, this brokenness is because 'not being glamorous is to fail at femininity, to fail at one's sex role' (2004: 163). Hershfield suggests that Doña Bárbara's 'gender confusion' may serve as a lesson:

Neither woman nor man, she has no identity according to Mexican patriarchal ideology, which recognises subjects first of all according to sexual difference. In the context of the narrative of the family melodrama, this could be read as a warning to Mexican women to retain their socially defined identity as a woman or suffer the consequence of nonidentity. (1996: 116)

Her behaviour points to the fact that gender is a performance, whose 'artifactual nature can be exposed by the strategy of the masquerade' (MacKinnon 2002: 12-13).

López criticises the fact that 'Bárbara remains unknowable, an enigma [...] whose subjectivity and desires the audience has no access to' (1993: 156). Arguably, however, this is where Doña Bárbara's power lies: in her refusal to allow full access to herself, particularly in the film version where the narrator cannot explain this character's behaviour and thought processes. This is precisely the pleasure of her character-a

\footnotetext{
${ }^{18}$ Monsiváis writes that 'la mujer fatal no cree en la monogamia' (1994b: 79).
} 
woman who has secrets and will not allow others power over her by having access to her authentic self. To try and achieve her aims with Luzardo, Doña Bárbara attempts the technique of seduction, which E. Ann Kaplan refers to as 'the bedazzling of the male' (as cited in Foster 1995). Seduction is the traditional recourse of women if they want to have any influence on men or the public world, and it denies the man a knowledge of a woman's real desires or purposes. María Félix, who adopted a personality similar to her 'autonomous woman' characters, insisted in an interview that 'no me seducen. Yo seduzco. [...] Tenemos tan pocas oportunidades las mujeres' (as cited in Cann 1996). Therefore, Doña Bárbara uses a number of strategies to empower herself in a maleorientated world.

Doña Bárbara represents the untamed and primitive, the rebellious Eve who in the end must be subjugated to the man. As Menon notes, like nature, female sexuality is associated with reproduction and it is seen as being hard to subjugate (2006: 134-35). This reflects the fact that the tale of the confrontation between Santos Luzardo and Doña Bárbara represents the clash between 'civilisation' and 'barbarism', which is a key dilemma in Latin American cultural history. Philip Swanson defines the civilisation/ barbarism dichotomy as

an anxiety about the state and direction of the relatively newly independent Latin American nations as they sought to consolidate a precarious sense of order, progress and modernity (usually associated with the emerging urban metropolises) in the face of a perceived threat of instability from the supposedly wild, untamed, chaotic, native masses (associated largely with the undeveloped interior).

This separation can be seen as artificial because it is 'a reflection of the particular interests of certain elite social groups' (2003: 69).

In the film, Doña Bárbara is also juxtaposed to civilisation and modernity through her superstition. Instead of asking God for help or relying on science and logic, she turns to witchcraft to aid her in her quest for dominance. This is perhaps not surprising considering that Doña Bárbara displays a distrust of men: by appealing to impersonal powers, she avoids submitting to the dominance of the male figure of God. This paganism is socially unacceptable and marks her as dangerous and associated with the Devil. Thus, Doña Bárbara subverts the patriarchal system in several ways: she does not answer to men, nor does she answer to a Catholic God. In fact, she does not even possess her father's surname. Marisela, Doña Bárbara's spurned daughter, sees what she is doing and insults her, calling her a witch.

Marisela is also a character associated with the barbarous, but she goes through a transformation process throughout the course of the film. Ignored by her unfeeling mother 
and uncomfortable living with her father, she is a 'backwards' young woman whose best friend is Doña Bárbara's simple worker Juan Primito. According to Luisela Alvaray, she becomes a virtuous character, as signified by her white dress (2009: 36). However, Marisela can be seen as representing nature, as shown by her often being on the ground. Moreover, Luzardo calls her an 'animalito de monte' before he makes her wash herself. Over time, Luzardo tames Marisela by dressing her in feminine clothes, teaching her appropriate behaviour, and educating her in the correct way of speaking. Indeed, Luzardo 'civilises' nature. The pair fall in love, which also gives Luzardo a weapon against Doña Bárbara, as Bárbara cannot bring herself to kill the doctor in the film's climax. When she sees how happy the two are together, she recalls the happiness that she shared with her boyfriend many years ago. She would be turning into the bad men who killed him, which is not something that she can do to her own daughter-and, perhaps, to herself.

Santos Luzardo is the opposite of Doña Bárbara in many ways, signifying the threat of modernity to that which is natural and unwieldy. He comes from 'civilisation' and is a doctor. He wants to build a fence, which he calls 'el punto de partida dentro del orden actual del progreso y de la civilización de la llanura'. This will be a clear line separating civilisation and order from Doña Bárbara's savage territory. He believes in the power of the law and tries to use it to his advantage. He finds that the magistrate is scared of Doña Bárbara and thus gives her whatever she wants. When Doña Bárbara receives a letter instructing her to present herself at his office she says that she is happy for the invitation, as a fight appeals to her and she knows that she can manipulate the weak magistrate. When Doña Bárbara threatens Luzardo with her witchcraft, he tells her the following: 'No se preocupe por sus brujerías. Siga con ellas'. This seems to suggest a rejection of old folk traditions and superstitions, because they are not related to progress or being effective. Luzardo is dismissive and patronising towards Doña Bárbara's practices because they represent the unscientific, ritualistic, and peripheral traditions of old-fashioned society. He clearly represents the nation itself, epitomising 'civilisation' and ultimately reining in 'barbarism'.

As King notes, 'the freedoms of María Félix's haughty characters are ultimately circumscribed by the strictures of the paternalist state which is personified in a series of male roles' (1990: 50). She is no match for the educated Luzardo, as her feelings make her weak in his presence. The man penetrates into her territory and conquers it, not by physical force or violence but by having stronger willpower and emotional control than the woman. Mary Beth Haralovich finds the following in mainstream films of this time:

If a woman is in a non-normative role in economic control and production, 
she will cede that control to a man by the end of the film. Romantic love seems to be the normative role which most strongly influences her decision. (As quoted in Kuhn 1982: 34)

Therefore, in line with Haralovich's observations, at the end of the film Doña Bárbara leaves the plantation thus allowing Luzardo to take it over. As Alvaray notes, 'in the end, romance overcomes all obstacles and reinforces conventional female and male roles' (2009: 36). She could remain and fight, but she understands that she has lost any hope of embarking on a romantic relationship with Luzardo and is therefore defeated. Her maleassociated power has been threatened by a true male and, of course, been found wanting, while her attempts at feminine seduction have failed her as well. Looking defeated, she comes back from her aborted mission to shoot Luzardo. She enters her bedroom, looks at her photo of Luzardo, still on the altar, and holds it to her chest, perhaps now accepting that this is the closest she will ever find herself to him. Then Doña Bárbara blows out the candles on the altar, knowing that her hope is lost. With no secure identity as a man or woman, she disappears from society. This melodramatic twist underscores the status quo, as it signals the triumph of Luzardo and 'civilisation' over Doña Bárbara, thus eradicating 'barbarism'.

A 'bad woman' like Doña Bárbara is often 'bad' partly because of her attitude toward motherhood. According to Stevens, 'by publicly deviating from the prescribed norm, she has divested herself of precisely those attributes considered most characteristically feminine and in the process has become somewhat masculine' (1973: 96). By rejecting motherhood or not devoting herself to it adequately, she is a 'bad' mother. According to Beauvoir, in the dominant patriarchal discourse 'to have a child is to take on a commitment; if the mother shrinks from it, she commits an offense against human existence' (2010: 566). Denying the 'maternal instinct' is seen as immoral: even a character with a difficult life like Margot in Las abandonadas is expected to do all that she can for the child that she bore. Doña Bárbara is an example of a failed mother, because she does not live up to society's expectation of a woman with a child. She disowns and ignores her daughter, Marisela, and instead of raising a child she focusses on maintaining the land she has acquired. In melodrama a daughter seems to only take from her mother, instead of giving back, as unlike a son she has little chance of 'escaping' the confines of being a woman (Kaplan 1987: 117). For example, Marisela in Doña Bárbara takes the man her mother wanted. Marisela is a competitor to her mother. The following observations from Beauvoir offer more insight into the mother-daughter relationship:

The pleasure man savours in women-feeling absolutely superior-is something a woman experiences only toward her children, and her daughters 
in particular; she feels frustration if she renounces these privileges and her authority. Whether she is a passionate or a hostile mother, her child's independence ruins her hopes. She is doubly jealous: of the world that takes her daughter, and of her daughter who, in conquering part of the world, robs her of it. (2010: 563)

In the absence of a mother, Marisela has formed a close bond with her father, associating herself with his world instead of her mother's. As Marisela sees her mother as an antagonist rather than as someone she wants in her life, she sets herself up in juxtaposition to her.

Tuñón writes that 'the love of two individuals is an attempt to regain paradise, but it is always thwarted by a third element' (1995: 190). As with Margot in Las abandonadas, Doña Bárbara's inability to be a good mother is the fault of society- the 'third element' that prevents a fairy-tale ending for Doña Bárbara. The actions of others have driven her to be a 'bad' woman and mother: specifically, her boyfriend being killed has led her to where she is. Because Doña Bárbara has been raped, she is damaged and unfit to be a mother, no better than a prostitute. In other words, society-particularly the actions of cruel men - is to blame for a distant or hostile mother. While a damaged woman such as Margot can still be a successful mother, in a way saving herself and redeeming her life by being the best mother she can be, she can also choose to shut off the 'maternal instinct' like Doña Bárbara does. The latter chooses casual relationships and an occupation over love and family, but the film suggests that she does this to avoid facing life and her 'natural' motherly duties. She does not deal with what has happened to her. In the novel the film is based on, Gallegos describes Doña Bárbara's response as she decides whether to shoot or not:

Se quedó contemplando largo rato a la hija feliz, y aquella ansia de formas nuevas que tanto la había atormentado tomó cuerpo en una emoción maternal, desconocida para su corazón.

-Es tuyo. Que te haga feliz. (1929: 276)

In keeping with the didacticism of the time, Doña Bárbara seems to eventually regret where her selfish choices have taken her and how her daughter has been used against her. However, she does not seem to consider that trying to be any kind of a mother to Marisela is an option, as she disappears from society altogether at the end of Doña Bárbara. Removing herself forever from her daughter's life only solidifies her 'abnormal' female nature and inability to understand motherhood.

To conclude, it could indeed be argued that the film essentially condemns Doña Bárbara for all her transgressions and does not allow for the possibility of redemption or empowerment at the end. Furthermore, she is also taught a lesson: no woman looking to 
be independent is going to survive in 'civilisation'. First through rape and then by taking her daughter away, men wipe Doña Bárbara from existence. 


\section{CONCLUSION}

It is hard to deny that the Mexican Revolution hovers over almost every film from the Golden Age of Mexican Cinema. The extent of the violence in 1910s and 1920s ensured that its consequences were bound to echo for decades to come. Some of the films are explicitly about the Mexican Revolution, but many of the others have at their centre the preoccupations brought about by the Mexican Revolution. As the previous chapters have repeatedly pointed out, the Mexican audiences processed these traumatic events through the popular films of the Golden Age. The films provided a place for Mexicans to read themselves into the stories and characters and thus to understand and cope with the changes brought on by sudden modernisation. Of course, the filmmakers were often working as part of the Revolutionary project and as such smoothed out many of the societal tensions.

However, while the political ideology of the time influenced the depictions, some of the stars and characters gave ample room for audiences to find inspiration and innovation. A clear example of such a figure is Pedro Infante, who undergoes some degree of what could be described as 'feminisation'. Infante and his characters suggest that Mexican masculinity needs to be more malleable and possibly incorporate acceptable male difference into a new concept of machismo that may perhaps be more fitting for the modern urban environment. Another example is María Félix, whose persona and characters, out of all the successful actresses in Mexican Golden Age cinema, probably challenged society's expected standard of a woman the most. Although her characters were still acceptable for males, as they were shown as being needed to put in their place, they were often atypical for their time, avoiding the extremes of the submissive women or the prostitute. The fact that they exceed the boundaries of male discourse puts her on the side of 'barbarism', and therefore outside the scope of the nationalist Revolutionary project. Such film images may have offered an escape and means of transcendence for both the film stars and their viewers. Therefore, while Mexican cinema from the 1940s may not set out to challenge traditional gender roles and stimulate examination of the place of religion, it offers many films that feature elements which facilitate a more modern approach.

The early 2000s offered a number of critically-acclaimed Mexican dramas with suggestive themes, such as the Oscar-nominated Amores perros (2000), Y tu mamá también (2001), and El crimen del padre Amaro (2002). The themes of such controversial, perhaps even iconoclastic, films are far removed from those of Golden Age films like 
Nosotros los pobres or Cuando los hijos se van. For example, El crimen del padre Amaro openly questions the power of the Church, while as M. S. Worrell notes $Y$ tu mamá también clearly 'demonstrates that artifice is essential for the maintenance of masculine self-identity under patriarchal masculinity' (2011: 158). However, recent years have seen a resurgence in highly successful Mexican films that do not openly challenge societal norms and instead concentrate on the importance of family. Two examples are Instructions Not Included (2013) and Nosotros los nobles (2013), which respectively were the third-highest grossing and seventh-highest grossing films of the year in Mexico. ${ }^{19}$ Although these films would not necessarily be classified as melodramas, their popular appeal is comparable to the success of the Mexican family and urban melodramas of the 1940s. Their themes are also similar. The title of Nosotros los nobles is a clear reference to Nosotros los pobres and its simple story is reminiscent of the 1948 film, particularly because they both illustrate how wealth can corrupt people.

However, unlike Nosotros los pobres, the stated intention of Nosotros los nobles is not to exalt the poor, but rather to humorously illustrate the gross economic divide between the rich and the poor in Mexico. ${ }^{20}$ This points to how popular, seemingly superficial films in Mexico could be used for encouraging discussion on important political issues instead of merely serving as a 'distraction'. As it was many decades ago during its Golden Age, Mexican cinema continues to offer possibilities for both distinctive entertainment and thematically rich stories.

\footnotetext{
${ }^{19} \mathrm{See}$ http://www.boxofficemojo.com/intl/mexico/yearly/?yr=2013\&p=.htm. These are the only Mexican films in the Top 30 - the rest are all Hollywood films

20 The director, Gary Alazraki, makes this claim in this CNN interview: https://www.youtube.com/watch?v=qCUsV574MaA.
} 


\section{Bibliography of Works Cited}

Adorno, Theodor W. 1991. The Culture Industry: Selected Essays on Mass Culture. Edited by J.M. Bernstein. London: Routledge.

Allen, Robert C. 1983. 'On Reading Soaps: A Semiotic Primer'. In Regarding Television: Critical Approaches-An Anthology, ed. E. Ann Kaplan, 97-108. Frederick, Md.: University Publications of America.

Allen, Virginia Mae. 1979. The Femme Fatale: A Study of the Early Development of the Concept in Mid-Twentieth Century Poetry and Painting. Ph.D. diss., Boston University.

Alvaray, Luisela. 2009. Melodrama and the Emergence of Venezuelan Cinema. In Latin American Melodrama: Passion, Pathos, and Entertainment, ed. Darlene J. Sadlier, 33-49. Urbana, Ill.; Chicago: University of Illinois Press.

Amezcua Castillo, Jesús. 2007. Pedro Infante: Medio siglo de idolatría. Mexico City: Ediciones B.

Andrade, A. Rolando. 1992. 'Machismo: A Universal Malady'. The Journal of American Culture 15, no. 4 (Winter): 33-41.

Arnold, Abby. 2003. 'The Rhetoric of Motherhood'. The Mothers Movement Online. http://www.mothersmovement.org/features/Copy/rhetoric-motherhood.pdf (accessed 2 September 2013).

Arredondo, Isabel. 2014. Motherhood in Mexican Cinema, 1941-1991: The Transformation of Femininity on Screen. Jefferson, N.C.: McFarland \& Company.

Ayala Blanco, Jorge. 1993. La aventura del cine mexicano: En la época de oro y después. Mexico City: Editorial Grijalbo.

Beauvoir, Simone de. 2010. The Second Sex. Translated by Constance Borde and Sheila Malovany-Chevallier. New York: Alfred A. Knopf.

Belton, John. 2009. American Cinema/ American Culture. 3d ed. New York: McGrawHill.

Benjamin, Walter. 1968. Illuminations. Edited by Hannah Arendt. Translated by Harry Zohn. New York: Schocken Books.

Berg, Charles Ramírez. 1992. Cinema of Solitude: A Critical Study of Mexican Film, 1967-1983. Austin: University of Texas Press.

1998. Preface to Carteles de la época de oro del cine mexicano/ Poster Art from the Golden Age of Mexican Cinema, by Rogelio Agrasánchez, Jr. and Charles Ramírez Berg, 7-47. Harlingen, Tex.: Archivo Fílmico Agrásanchez; Guadalajara, Jal.: Universidad de Guadalajara.

Bird, Sharon R. 1996. 'Welcome to the Men's Club: Homosociality and the Maintenance of Hegemonic Masculinity'. Gender \& Society 10, no. 2 (April): 120-32. 
Bray, Alan. 2002. 'Homosexuality and the Signs of Male Friendship'. In The Masculinity Studies Reader, eds. Rachel Adams and David Savran, 340-54. Malden, Mass.; Oxford: Blackwell Publishers.

Brooks, Peter. 1976. The Melodramatic Imagination: Balzac, Henry James, Melodrama, and the Mode of Excess. New Haven, Conn.: Yale University Press.

Brown, Judith. 2010. 'Garbo's Glamour'. In Modernist Star Maps: Celebrity, Modernity, Culture, eds. Aaron Jaffe and Jonathan Goldman, 107-21. Farnham, Surrey; Burlington, Vt.: Ashgate Publishing.

Budowski, Monica. 2005. Dignity and Daily Practice: The Case of Lone Mothers in Costa Rica. Münster: LIT Verlag.

Burton-Carvajal, Julianne. 1997. 'Mexican Melodramas of Patriarchy: Specificity of a Transcultural Form'. In Framing Latin American Cinema: Contemporary Critical Perspectives, ed. Ann Marie Stock, 186-234. Minneapolis, Minn.: University of Minnesota Press.

Bush, Matthew. 2014. Pragmatic Passions: Melodrama and Latin American Social Narrative. Orlando: Iberoamericana Editorial Vervuert.

Cann, Benjamín. 1996. María Félix: Una conversación, Parte 1. Televisa. Documentary.

Carrasco Vázquez, Jorge. 2005. Pedro Infante, un mito siempre joven. Mexico City: Grupo Editorial Tomo.

Castañeda, Jorge G. 2011. Mañana Forever?: Mexico and the Mexicans. New York: Alfred A. Knopf.

Cawelti, John G. 1991. 'The Evolution of Social Melodrama'. In Imitations of Life: A Reader on Film and Television Melodrama, ed. Marcia Landy, 33-49. Detroit, Mich.: Wayne State University Press.

Cherchi Usai, Paolo. 2011. 'A Trip to the Movies: Georges Méliès, Filmmaker and Magician (1861-1938)'. In Fantastic Voyages of the Cinematic Imagination: Georges Méliès's Trip to the Moon, ed. Matthew Solomon, 25-30. Albany: State University of New York Press.

Cohan, Steve. 1997. Masked Men: Masculinity and the Movies in the Fifties. Bloomington: Indiana University Press.

Colina, Enrique, and Daniel Díaz Torres. 1978. 'Ideology of Melodrama in the Old Latin American Cinema'. In Latin American Film Makers and the Third Cinema, ed. Zuzana M. Pick, 46-70. Ottawa: Carleton Film Studies.

Collins, Lindsey. 2010. 'Landscapes of Gendered Violence: Male Love and Anxiety on the Railroad'. In The Philosophy of the Western, eds. Jennifer L. McMahon and B. Steve Csaki, 89-110. Lexington: The University Press of Kentucky.

Craske, Nikki. 2003. 'Gender and Sexuality in Latin America'. In The Companion to Latin American Studies, ed. Philip Swanson, 200-21. London: Arnold. 
Crawley, Eduardo. 1984. A House Divided: Argentina 1880-1980. London: C. Hurst.

Dally, Ann. 1982. Inventing Motherhood: The Consequences of an Ideal. London: Burnett Books Limited.

DeCordova, Richard. 2001. Picture Personalities: The Emergence of the Star System in America. Champaign, Ill.: University of Illinois Press.

De la Mora, Sergio. 2006. Cinemachismos: Masculinities and Sexuality in Mexican Film. Austin: University of Texas Press.

De la Vega Alfaro, Eduardo. 1995. 'Origins, Development and Crisis of the Sound Cinema (1929-64)'. In Mexican Cinema, ed. Paulo Antonio Paranaguá, 79-93. London: British Film Institute.

De la Peza, Carmen. 1998. Cine, melodrama y cultura de masas: Estética de la antiestética. Mexico City: Consejo Nacional para la Cultura y las Artes.

De los Reyes, Aurelio. 1995. 'The Silent Cinema'. In Mexican Cinema, ed. Paulo Antonio Paranaguá, 63-78. London: British Film Institute.

Dever, Susan. 2003. Celluloid Nationalism and Other Melodramas: From PostRevolutionary Mexico to fin de siglo Mexamérica. Albany: State University of New York Press.

Doane, Mary Ann. 1991. Femmes Fatales: Feminism, Film Theory, and Psychoanalysis. New York; London: Routledge.

Domínguez-Ruvalcaba, Héctor. 2007. Modernity and the Nation in Mexican Representations of Masculinity: From Sensuality to Bloodshed. New York: Palgrave Macmillan.

Doremus, Anne T. 2000. 'Authenticity, the Pelado and the Mexican National Identity: Essay versus Film during the 1930s and the 1940s'. Confluencia 16, no. 1 (Fall): $35-48$.

- 2001. Culture, Politics, and National Identity in Mexican Literature and Film, 1929-1952. New York: Peter Lang Publishing.

Dorfman, Ariel, and Armand Mattelart. 1975. How to Read Donald Duck: Imperialist Ideology in the Disney Comic. New York: I.G. Editions.

Durgnat, Raymond. 1967. Films and Feelings. London: Faber and Faber Limited.

Dyer, Richard. 1982. 'Don’t Look Now'. Screen 23 (September/ October): 61-73.

—. 1993, 2002. The Matter of Images: Essays on Representation. 2d ed. London; New York: Routledge.

—. 2002. 'The White Man's Muscles'. In The Masculinity Studies Reader, eds. Rachel Adams and David Savran, 262-73. Malden, Mass.; Oxford: Blackwell Publishers. 
- 2004. Heavenly Bodies: Film Stars and Society. 2d ed. Oxon; New York: Routledge.

Fein, Seth. 2001. 'Myths of Cultural Imperialism and Nationalism in Golden Age Mexican Cinema'. In Fragments of a Golden Age: The Politics of Culture in Mexico Since 1940, eds. Gilbert M. Joseph, Anne Rubenstein, and Eric Zolov, 159-98. Durham, N.C.: Duke University Press.

Forster, E. M. 1971. Maurice. London: Edward Arnold.

Foster, David William. 1997. 'Queering the Patriarchy in Hermosillo's Doña Herlinda y su hijo'. In Framing Latin American Cinema: Contemporary Critical Perspectives, ed. Ann Marie Stock, 235-45. Minneapolis, Minn.: University of Minnesota Press.

Foster, Lilibet. 1995. 'Writing and Thinking about Film'. American Cinema. St. Louis, Mo.: Annenberg Learner. Documentary.

Franco, Jean. 1986. 'Plotting Women: Popular Narratives for Women in the United States and in Latin America'. In Reinventing the Americas, eds. Bell Gale Chevigny and Gari Laguardia, 249-68. Cambridge; New York: Cambridge University Press.

Franklin, Sarah L. 2012. Women and Slavery in Nineteenth-Century Colonial Cuba. Rochester, N.Y.: University of Rochester Press.

Gallegos, Rómulo. 1929. Doña Bárbara. Madrid: Espasa-Calpe.

García, Gustavo. 1995. 'Melodrama: The Passion Machine'. In Mexican Cinema, ed. Paulo Antonio Paranaguá, 153-62. London: British Film Institute.

García Riera, Emilio. 1998. Breve historia del cine mexicano: Primer siglo, 1897-1997. Mexico City: Instituto Mexicano de Cinematografía; Zapopan, Jalisco: Ediciones Mapa SA de CV.

Gledhill, Christine. 1987. 'The Melodramatic Field: An Investigation'. In Home Is Where the Heart Is, ed. Christine Gledhill, 5-39. London: British Film Institute.

Gorman, Paul R. 1996. Left Intellectuals and Popular Culture in Twentieth-Century America. Chapel Hill, N.C.: University of North Carolina Press.

Gottdiener, Mark. 1985. 'Hegemony and Mass Culture: A Semiotic Approach'. American Journal of Sociology 90, no. 5 (March): 979-1001.

Gramsci, Antonio. 1971. Selections from the Prison Notebooks. Edited and translated by Quintin Hoare and Geoffrey Nowell Smith. New York: International Publishers.

Gruzinski, Serge. 2001. Images at War: Mexico from Columbus to Blade Runner (14922019). Translated by Heather MacLean. Durham, N.C.: Duke University Press.

Haddu, Miriam. 2007. Contemporary Mexican Cinema, 1989-1999: History, Space, and Identity. Lewiston, N.Y.; Queenston, Ont.; Lampeter, Ceredigion: The Edwin Mellen Press. 
Hall, Linda B. 2013. Dolores del Río: Beauty in Light and Shade. Stanford, Calif.: Stanford University Press.

Hall, Stuart. 1980. 'Encoding/Decoding'. In Culture, Media, Language: Working Papers in Cultural Studies, 1972-1979, ed. Stuart Hall, 117-27. Florence, Ky.: Routledge.

Hardin, Michael. 2002. 'Altering Masculinities: The Spanish Conquest and the Evolution of the Latin American Machismo'. International Journal of Sexuality and Gender Studies 7, no. 1 (January): 1-22.

Hershfield, Joanne. 1996. Mexican Cinema/ Mexican Women, 1940-1950. Tucson, Ariz.: University of Arizona Press.

Horkheimer, Max, and Theodor W. Adorno. 1972. Dialectic of Enlightenment. New York: Herder and Herder.

Horrocks, Roger. 1995. Male Myths and Icons: Masculinity in Popular Culture. New York: St. Martin's Press.

Howe, James, and Lawrence A. Hirschfeld. 1981. 'The Star Girls' Descent: A Myth about Men, Women, Matrilocality, and Singing'. The Journal of American Folklore 94, no. 373 (July-September): 292-322.

Irwin, Robert McKee. 2003. Mexican Masculinities. Minneapolis, Minn.: University of Minnesota Press.

John, Juliet. 2001. Dickens's Villains: Melodrama, Character, Popular Culture. Oxford; New York: Oxford University Press.

Joseph, Gilbert M., Anne Rubenstein, and Eric Zolov. 2001. 'Assembling the Fragments: Writing a Cultural History of Mexico Since 1940'. In Fragments of a Golden Age: The Politics of Culture in Mexico Since 1940, eds. Gilbert M. Joseph, Anne Rubenstein, and Eric Zolov, 3-22. Durham, N.C.: Duke University Press.

Kaplan, E. Ann. 1987. 'Mothering, Feminism, and Representation: The Maternal in Melodrama and the Woman's Film 1910-1940'. In Home Is Where the Heart Is, ed. Christine Gledhill, 113-37. London: British Film Institute.

King, John. 1990. Magical Reels: A History of Cinema in Latin America. London; New York: Verso.

Kuhn, Annette. 1982. Women's Pictures: Feminism and Cinema. London; New York: Routledge \& Kegan Paul.

Landy, Marcia. 1991. Introduction to Imitations of Life: A Reader on Film and Television Melodrama, ed. Marcia Landy, 13-30. Detroit, Mich.: Wayne State University Press.

Lehman, Peter. 2007. Running Scared. Detroit, Mich.: Wayne State University Press.

Lindauer, Margaret A. 1999. Devouring Frida: The Art History and Popular Celebrity of Frida Kahlo. Hanover, N.H.: Wesleyan University Press. 
López, Ana M. 1991. 'The Melodrama in Latin America: Films, Telenovelas, and the Currency of a Popular Form'. In Imitations of Life: A Reader on Film and Television Melodrama, ed. Marcia Landy, 596-606. Detroit, Mich.: Wayne State University Press.

—. 1993. 'Tears and Desire: Women and Melodrama in the "Old" Mexican Cinema'. In Mediating Two Worlds: Cinematic Encounters in the Americas, eds. John King, Ana M. López, and Manuel Alvarado, 147-63. London: British Film Institute.

MacKinnon, Kenneth. 1997. Uneasy Pleasures: The Male as Erotic Object. London: Cygnus Arts.

- 2002. Love, Tears, and the Male Spectator. Madison, N.J.: Fairleigh Dickinson University Press.

Martín-Barbero, Jesús. 1993. Communication, Culture and Hegemony: From the Media to Mediations. Translated by Elizabeth Fox and Robert A. White. London: SAGE Publications.

McDonald, Paul. 2000. The Star System: Hollywood's Production of Popular Identities. London: Wallflower Press.

Melhuus, Marit. 1996. 'Power, Value and the Ambiguous Meanings of Gender'. In Machos, Mistresses, Madonnas: Contesting the Power of Latin American Gender Imagery, eds. Marit Melhuus and Kristi Anne Stølen, 230-59. London; New York: Verso.

Menon, Elizabeth K. 2006. Evil by Design: The Creation and Marketing of the Femme Fatale. Urbana, Ill.; Chicago: University of Illinois Press.

Monsiváis, Carlos. 1993. 'Mexican Cinema: Of Myths and Demystifications.' In Mediating Two Worlds: Cinematic Encounters in the Americas, eds. John King, Ana M. López, and Manuel Alvarado, 139-46. London: British Film Institute.

—. 1994a. 'Se sufre, pero se aprende (El melodrama y las reglas de la falta de límites).' In A través del espejo: El cine mexicano y su público, eds. Carlos Monsiváis and Carlos Bonfil, 99-224. México, D.F.: Ediciones El Milagro.

- 1994b. 'Vino todo el pueblo y no cupo en la pantalla.' In A través del espejo: El cine mexicano y su público, eds. Carlos Monsiváis and Carlos Bonfil, 49-97. México, D.F.: Ediciones El Milagro.

—. 1995a. 'All the People Came and Did Not Fit onto the Screen: Notes on the Cinema Audience in Mexico.' In Mexican Cinema, ed. Paulo Antonio Paranaguá, 145-51. London: British Film Institute.

1995b. 'Mythologies.' In Mexican Cinema, ed. Paulo Antonio Paranaguá, 117-32. London: British Film Institute.

—. 1997. Mexican Postcards. Translated by John Kraniauskas. London; New York: Verso.

2008. Pedro Infante: Las leyes del querer. Mexico City: Editorial Aguilar. 
Mora, Carl J. 1982. Mexican Cinema: Reflections of a Society 1896-1980. Berkeley: University of California Press.

Mraz, John. 1999. 'The Revolution is History: Filming the Past in Mexico and Cuba'. Film-Historia 2: http://www.publicacions.ub.es/bibliotecadigital/cinema/ filmhistoria/Art.Mraz.pdf (accessed 20 November 2014).

Neale, Steve. 1986. 'Melodrama and Tears'. Screen 27, no. 6: 6-23.

Newcomer, Daniel. 2004. Reconciling Modernity: Urban State Formation in 1940s León, Mexico. Lincoln, Nebr.: University of Nebraska Press.

Noble, Andrea. 2005. Mexican National Cinema. London; New York: Routledge.

Ocasio, Rafael. 2010. 'La apropiación de María Félix del icónico personaje en Doña Bárbara de Rómulo Gallegos'. Romance Quarterly 57, no. 4: 273-85.

O'Shea, Alan, and Bill Schwarz. 1987. 'Reconsidering Popular Culture'. Screen 28, no. 3 (Summer): 104-09.

Paz, Octavio. 1985. The Labyrinth of Solitude. In The Labyrinth of Solitude and Other Writings, 7-212. Translated by Lysander Kemp. New York: Grove Press.

Poniatowska, Elena. 2001. 'Taking Mexican Popular Culture by Storm'. Foreword to Fragments of a Golden Age: The Politics of Culture in Mexico Since 1940, eds. Gilbert M. Joseph, Anne Rubenstein, and Eric Zolov, xi-xiv. Durham, N.C.: Duke University Press.

Pronger, Brian. 1992. 'Gay Jocks: A Phenomenology of Gay Men in Athletics'. In Rethinking Masculinity: Philosophical Explorations in Light of Feminism, eds. Larry May and Robert A. Strikwerda, 41-55. Lanham, Md.: Rowman \& Littlefield Publishers.

Purnell, Jennie. 1999. Popular Movements and State Formation in Revolutionary Mexico: The Agraristas and Cristeros of Michoacán. Durham, N.C.: Duke University Press.

Rowe, William. 1987. Rulfo: El llano en llamas. London; Wolfeboro, N.H.: Grant \& Cutler Ltd.

Rowe, William, and Vivian Schelling. 1991. Memory and Modernity: Popular Culture in Latin America. London; New York: Verso.

Rubenstein, Anne. 2001. 'Bodies, Cities, Cinema: Pedro Infante's Death as Political Spectacle'. In Fragments of a Golden Age: The Politics of Culture in Mexico Since 1940, eds. Gilbert M. Joseph, Anne Rubenstein, and Eric Zolov, 199-233. Durham, N.C.: Duke University Press.

Ryken, Leland. 1991. Realms of Gold: The Classics in Christian Perspective. Wheaton, Ill.: Harold Shaw Publishers.

Sammons, Jeffrey T. 1988. Beyond the Ring: The Role of Boxing in American Society. Urbana; Chicago: University of Illinois Press. 
Sarlo, Beatriz. 2001. Scenes from Postmodern Life. Translated by Jon Beasley-Murray. Minneapolis, Minn.: University of Minnesota Press.

Sedgwick, Eve Kosofsky. 1985. Between Men: English Literature and Male Homosocial Desire. New York: Columbia University Press.

Seidler, Victor J. 1989. Rediscovering Masculinity: Reason, Language, and Sexuality. London; New York: Routledge.

Sequeira, David. 2009. The Machismo and Marianismo Tango. Pittsburgh: Dorrance Publishing.

Sorensen, Roy. 2003. A Brief History of the Paradox: Philosophy and the Labyrinths of the Mind. Oxford; New York: Oxford University Press.

Stechler, Amy. 2004. The Life and Times of Frida Kahlo. Daylight Films. Documentary.

Stevens, Evelyn P. 1973. 'Marianismo: The Other Face of Machismo'. In Female and Male in Latin America, ed. Ann Pescatello, 89-101. Pittsburgh, Penn.: University of Pittsburgh Press.

Storey, John. 2001. Cultural Theory and Popular Culture: An Introduction. 3d ed. Harlow, Essex: Pearson Education Limited.

Swanson, Philip. 2003. "Civilisation and barbarism"'. In The Companion to Latin American Studies, ed. Philip Swanson, 69-85. London: Arnold.

Sydie, R.A. 1994. Natural Women, Cultured Men: A Feminist Perspective on Sociological Theory. Vancouver: UBC Press.

Toda, María de los Ángeles. 2001. 'The Construction of Male-Male Relationships in the Edwardian Age: E. M. Forster's Maurice, H. A. Vachell's The Hill, and Public School Ideology'. Atlantis 23, no. 2 (December): 133-45.

Torgovnich, Marianna. 1991. Gone Primitive: Savage Intellects, Modern Lives. Chicago: University of Chicago Press.

Tuñón, Julia. 1994. 'La silueta de un vacío: Imágenes fílmicas de la familia mexicana en los años cuarenta'. Film-Historia 4, no. 2: 137-47.

—. 1995. 'Emilio Fernández: A Look Behind the Bars'. In Mexican Cinema, ed. Paulo Antonio Paranaguá, 179-92. Translated by Ana M. López. London: British Film Institute.

-1998. Mujeres de luz y sombra en el cine mexicano: La construcción de una imagen, 1939-1952. Mexico City: El Colegio de México/ Instituto Mexicano de Cinematografía. Cinematografía.

Viviani, Christian. 1987. 'Who Is Without Sin?: The Maternal Melodrama in American Film, 1930-1939'. Translated by Dolores Burdich. In Home Is Where the Heart Is, ed. Christine Gledhill, 83-99. London: British Film Institute. 
Webb, William J. 2001. Slaves, Women, and Homosexuals: Exploring the Hermeneutics of Cultural Analysis. Downers Grove, Ill.: InterVarsity Press.

Williams, Linda. 1991. 'Film Bodies: Gender, Genre, and Excess'. Film Quarterly 44, no. 4 (Summer): 2-13.

Williams, Raymond. 1973. The Country and the City. New York: Oxford University Press.

Worrell, M. S. 2011. 'Sexual Awakenings and the Malignant Fictions of Masculinity in Alfonso Cuarón's $Y$ tu mamá también'. In Sex and the Citizen: Interrogating the Caribbean, ed. Faith Smith, 157-67. Charlottesville, Va.: University of Virginia Press. 